\title{
Dins Šmits
}

\section{TREATMENT ADHERENCE OF ASTHMA PATIENTS IN LATVIA AND FACTORS RELATED TO ADHERENCE}

The Doctoral Thesis for obtaining the degree of a Doctor of Medicine Specialty - Medicine Subspecialty - Public Health 
Dins Šmits

\section{TREATMENT ADHERENCE OF ASTHMA PATIENTS IN LATVIA AND FACTORS RELATED TO ADHERENCE}

The Doctoral Thesis

for obtaining the degree of a Doctor of Medicine

Specialty - Medicine

Subspecialty - Public Health

Scientific supervisor:

Dr. med., Professor Ģirts Briǵis

Rīga, 2018 


\section{ENGLISH ABSTRACT}

Introduction: the problem of nonadherence to the therapy is one of the main reasons of insufficient asthma control. Evaluating the beliefs about asthma medication, cognitive and emotional perceptions may help to identify patients with poor adherence to treatment in clinical practice in order to provide additional attention in order to increase the likelihood to take their asthma medication regularly.

Objective: the general objective of this study was to find out whether beliefs about asthma medication, cognitive and emotional factors are associated with asthma treatment and control in a sample of Latvian asthma patients in 2015. In addition, we wanted to assess whether the most commonly used questionnaires predicting treatment adherence can predict asthma control and treatment adherence.

Methods: the study population of this cross-sectional patient survey consisted of asthma patients $(n=352)$ attending outpatient pulmonologist consultations in Latvia during September 2013 to December 2015. Beliefs about asthma medicine, cognitive and emotional factors related to asthma were determined in a cross-sectional survey of patients attending outpatient pulmonologist practices in Latvia. Level of asthma control were assessed using the Asthma control test (ACT), a validated five-item scale that reliably assesses asthma control over a recall period of four weeks. Beliefs about medication, cognitive and emotional factors was assessed using The validated Beliefs about Medicines Questionnaire (BMQ) and the Brief Illness Perception Questionnaire (brief IPQ). Adherence to asthma medication was assessed using the Morisky Medication Adherence Scale (MMAS) and two different versions of the Medication Adherence Reporting Scale (MARS). Logistic regression models were used to predict poor adherence to asthma treatment.

Results: patients who had a good control of asthma medication (OR 0.70; 95\% CI 0.61-0.79) or were confident that their asthma medication improves illness (OR $0.84 ; 95 \% \mathrm{CI}$ $0.74-0.95$ ) had a reduced risk of poor asthma control. The more symptoms (OR 1.63; 95\% CI 1.44-1.84) asthma patients perceived or the more their illness affected their life, the higher the probability of poor asthma control (OR 1.47; 95\% CI 1.31-1.65). Several questions about necessity or concerns related to pharmaceutical treatment were able to predict poor adherence according to the Morisky scale. If the patient felt that without the asthma medication his life would be impossible, his risk to have poor treatment adherence was $46 \%$ reduced (OR 0.54 ; 95\% Confidence interval (CI) 0.33-0.89). Furthermore, asthma patients who were convinced that their health depends on asthma treatment were less likely to have poor treatment adherence (OR 0.56: 95\% CI 0.32-0.97). In case the patient was concerned by the need to constantly use 
asthma medication or sometimes concerned by long term effects of asthma medication the odds of poor treatment adherence were 1.96 (95\% CI 1.19-3.24) and 2.43 (95\% CI 1.45-4.08), respectively.

Conclusions: medication beliefs, particularly concerns and necessity of asthma treatment were associated with poor treatment adherence when assessed with the Morisky or 5-item MARS scale. We recommend using either the MMAS or the 5-item MARS scale in Latvian asthma patients to identify patients with poor treatment adherence. Existing questionnaires assessing beliefs of medication necessity (Beliefs about Medications Questionnaire, BMQ), cognitive or emotional illness perception (Brief Illness Perception Questionnaire, IPQ) may be used to identify patients with poor asthma control, in order to help to identify problems of poor control and offering better treatment solutions. Thus, it may be worthwhile to assess routinely the concerns and necessity of asthma medication in patients within the Latvian health-care system to improve treatment adherence in that vulnerable population group to improve treatment outcomes and disease control. 


\section{KOPSAVILKUMS LATVIEŠU VALODĀ}

\section{Ievads}

Viens no galvenajiem bronhiālās astmas nepietiekamas kontroles iemesliem ir pacientu līdzestības ārstēšanai trūkums. Pacientu uzskatu par bronhiālās astmas terapiju, pacientu kognitīvo un emocionālo sava veselības stāvokḷa uztveres līmeņa novērtēšana var palīdzēt identificēt pacientus ar vāju izpildes līdzestību terapijai klīniskajā praksē. Tas ļautu pievērst papildu uzmanību šādiem pacientiem un palielināt varbūtību, ka pacienti regulāri lieto viņiem nozīmētos bronhiālās astmas medikamentus.

\section{Mērķisis}

Pētījuma pamatmērķis bija izzināt, vai pastāv sakarība starp pacientu uzskatiem par bronhiālās astmas terapiju, viṇu kognitīvo un emocionālo uztveri par slimību un bronhiālās astmas terapiju un kontroli Latvijas astmas pacientu 2015. gada iztvēruma grupā. Papildu mērķis bija novērtēt, vai izpildes līdzestības prognozēšanā plašāk lietotās pacientu aptaujas anketas var lietot astmas kontroles un terapijas prognozēm.

\section{Metodes}

Šì šksērsgriezuma pētījuma pacientu populācija ietver bronhiālās astmas pacientus ( $\mathrm{n}=352)$, kas ambulatori ārstējās pneimonologu prakses vietās Latvijā, laikā no 2013. gada septembra līdz 2015. gada decembrim. Pacientu uzskatus attiecībā uz bronhiālās astmas terapiju, kā arī sava bronhiālās astmas stāvokḷa kognitīvo un emocionālo uztveri noteica šksērsgriezuma pētījumā, pacientiem atbildot uz aptauju jautājumiem, ambulatorās pneimonologu prakses vietās Latvijā. Astmas kontroles pakāpe tika noteikta, izmantojot astmas kontroles testu (Asthma Control Test, ACT), kas ir validēta piecu punktu skala, ar kuras palīdzību ticami var novērtēt astmas kontroli četru nedēḷu novērojuma periodā. Uzskatus par ārstēšanu un kognitīvo un emocionālo slimības uztveri noteica, izmantojot validētu aptaujas anketu Uzskati par ārstēšanu (Beliefs about Medications Questionnaire, BMQ) un validētu Īso aptauju par kognitīvo un emocionālo slimības uztveri (Brief Illness Perception Questionnaire, $I P Q)$. Izpildes līdzestību bronhiālās astmas terapijai noteica, izmantojot Moriski līdzestības ārstēšanai skalu (Morisky 8-Item Medication Adherence Questionnaire, MMAS), ka arī Līdzestības ārstēšanai pārskata skalas (Medication Adherence Report Scale, MARS) divas dažādas versijas. Bronhiālās astmas ārstēšanas sliktas izpildes līdzestības prognozēšanai tika izmantota loǵistiskās regresijas analīze. 


\section{Rezultāti}

Pacientiem, kuri uzskatīja, ka viņiem ir pietiekama kontrole pār savu slimību (OR 0,70; 95\% CI 0,61-0,79) un, kuri bija pārliecināti, ka bronhiālās astmas terapija uzlabo viņu slimības stāvokli (OR 0,84; 95\% CI 0,74-0,95), bija mazāks astmas sliktas kontroles risks. Jo vairāk klīnisko simptomu (OR 1,63; 95\% CI 1,44-1,84) bronhiālās astmas pacienti sev saskatīja un jo vairāk slimība ietekmēja viṇu dzīvi, jo lielāka bija astmas sliktas kontroles varbūtība (OR 1,47; 95\% CI 1,31-1,65). Saskaņā ar Moriski skalu daži jautājumi par medikamentu nepieciešamību un bažas par to lietošanu l̦auj prognozēt sliktu izpildes līdzestību. Ja pacientam bija sajūta, ka bez bronhiālās astmas terapijas viņa dzīve nebūs iespējama, sliktas izpildes līdzestības risks samazinājās par 46\% (OR 0,54; 95\% ticamības intervāls (CI) 0,33-0,89). Turklāt bronhiālās astmas pacientiem, kuri bija pārliecināti par savas veselības atkarību no bronhiālās astmas terapijas, bija mazāka varbūtība būt nelīdzestīgiem ārstēšanai (OR 0,56: 95\% CI 0,32-0,97). Gadījumā, ja pacients bažījās par nepieciešamību pastāvīgi lietot bronhiālās astmas medikamentus vai pacientam dažreiz bija bažas par astmas medikamentu iedarbību ilgākā laika periodā, varbūtība, ka šiem pacientiem būs slikta izpildes līdzestība bija attiecīgi 1,96 (95\% CI $1,19-3,24)$ un $2,43(95 \%$ CI $1,45-4,08)$.

\section{Secinājumi}

Pacientu uzskati par ārstēšanu, it īpaši bažas un vajadzības sajūta par nepieciešamību ārstēt bronhiālo astmu, uzrādīja saistību ar pacienta sliktu izpildes līdzestību, to nosakot pēc Morisky skalas vai pēc 5 punktu MARS skalas. Kā piemērotas Latvijas bronhiālās astmas pacientu populācijā rekomendējam izmantot gan MMAS skalu, gan MARS 5 punktu skalu, lai identificētu astmas pacientus ar sliktu izpildes līdzestību ārstēšanai. Šobrīd pieejamās pacientu aptaujas anketas, ar kurām nosaka pacientu uzskatus par nepieciešamību ārstēties (Beliefs about Medications Questionnaire, BMQ), kā arī kognitīvo un emocionālo savas slimības uztveri (Brief Illness Perception Questionnaire, IPQ), var praktiski lietot, ja nepieciešams identificēt slikti kontrolētas bronhiālās astmas pacientus. Pacientu aptaujas anketas atbilstoši tajos ietverto jautājumu saturam var palīdzēt ārstam identificêt bronhiālās astmas sliktas kontroles iemeslus un tā rezultātā apsvērt pacientam piemērotāku ārstēšanu, kas tam labāk varētu palīdzēt sasniegt slimības kontroli. Noderīgi būtu ikdienas klīniskajā praksē Latvijas veselības aprūpes sistēmā bronhiālās astmas ārstēšanā ieviest pacientu uzskatu, kognitīvās un emocionālās uztveres mērījumus, tādējādi uzlabojot ārstēšanas rekomendāciju izpildes līdzestību un ārstēšanas rezultātus un slimības kontroli šajā slimnieku populācijas grupā. 


\section{CONTENT}

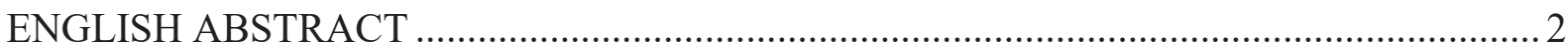

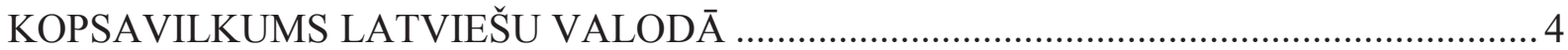

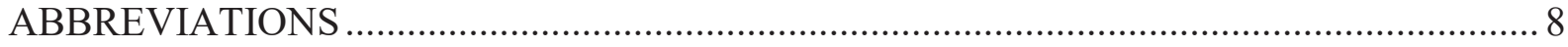

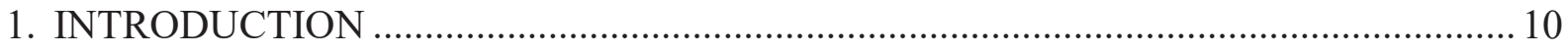

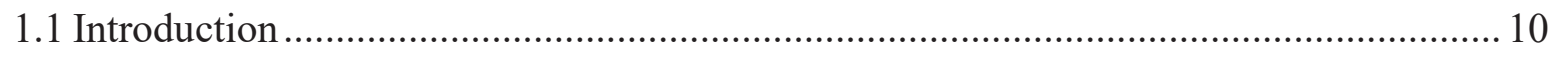

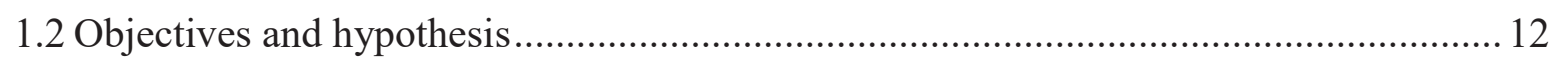

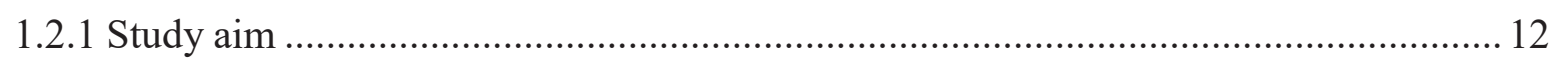

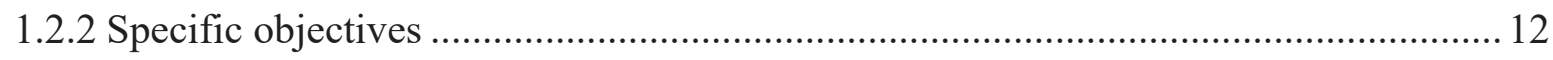

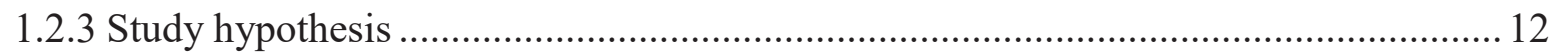

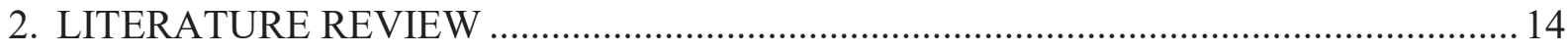

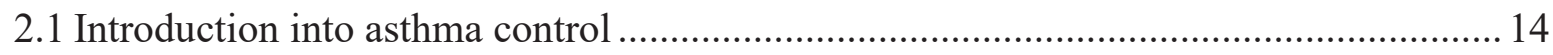

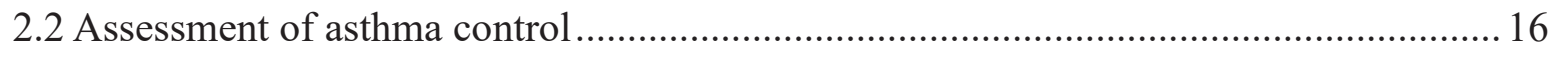

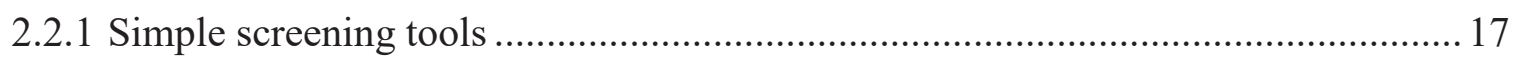

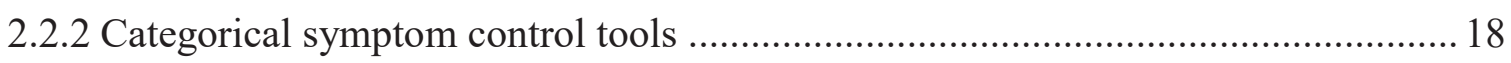

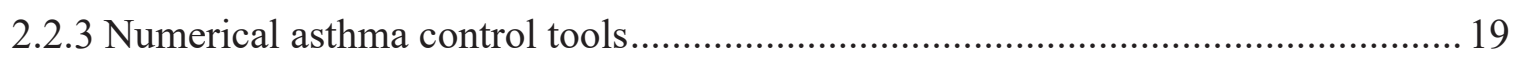

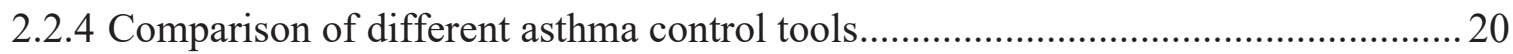

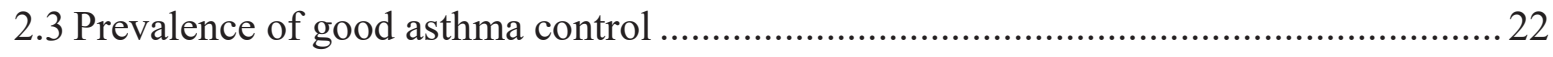

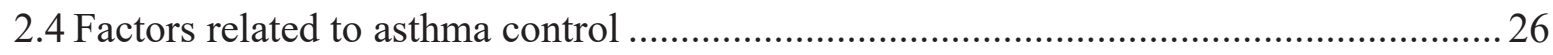

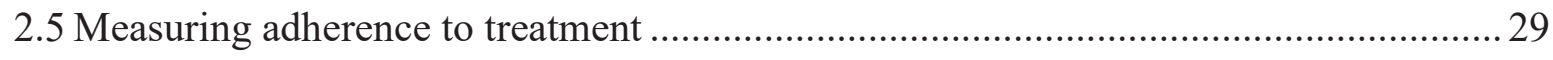

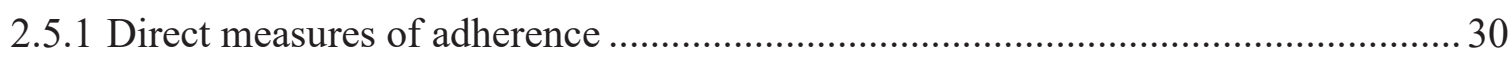

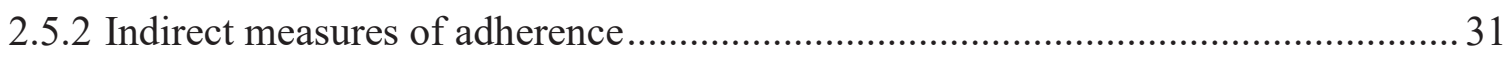

2.6 Factors related to medical adherence in asthma patients .......................................... 35

2.6.1 Definition, characteristics and prevalence of treatment adherence in asthma patients .

2.6.2 Patients' beliefs about medications and adherence: the necessity-concerns framework

2.6.3 Patients' illness perception and adherence ........................................................... 39

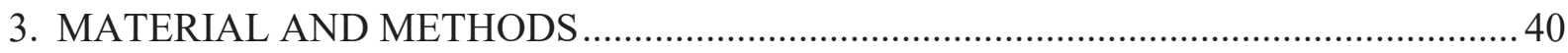

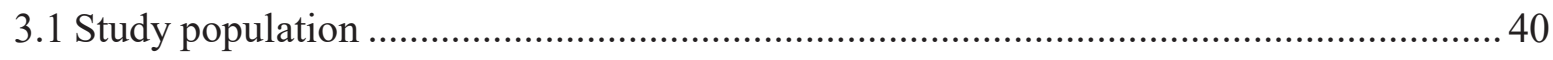

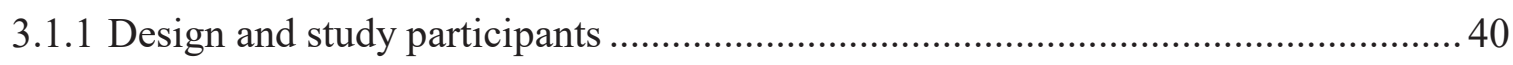

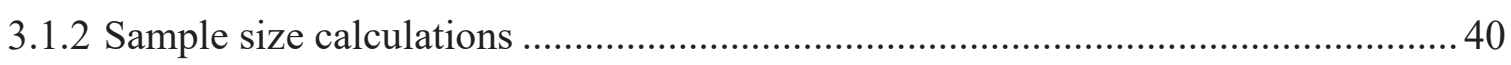

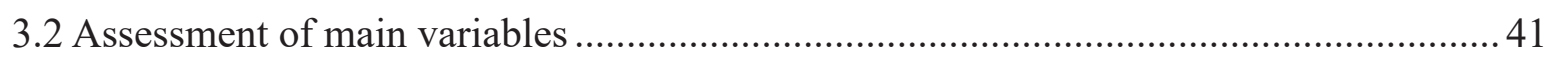

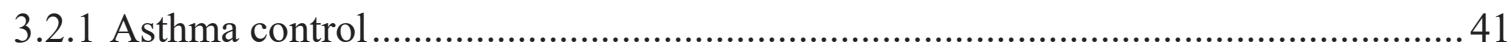

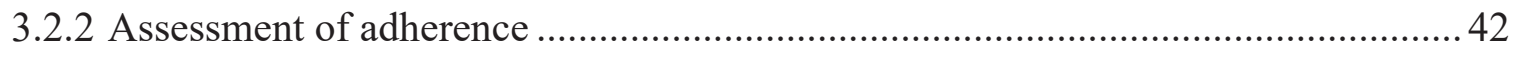

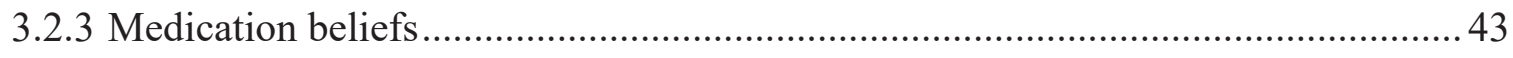

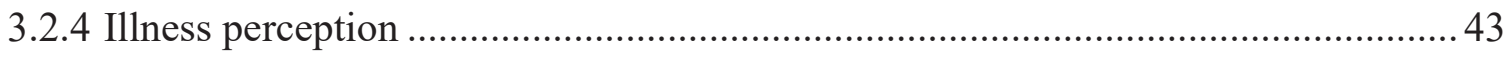

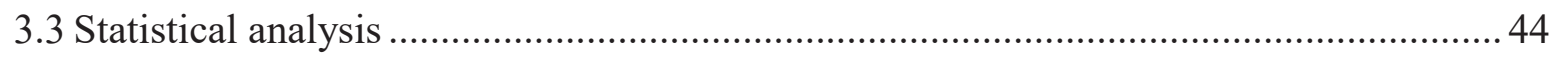




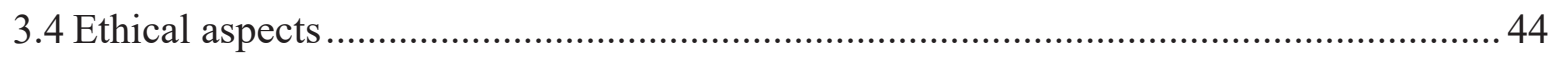

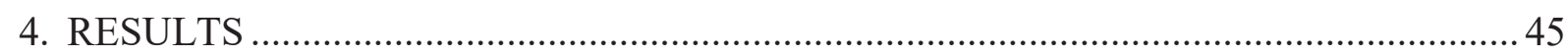

4.1 Sociodemographic and socio-economic factors associated with poor

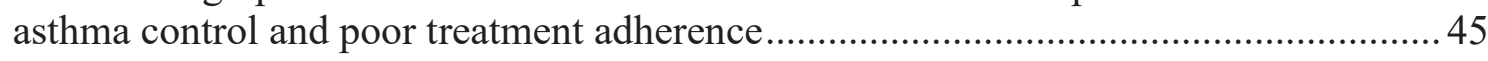

4.2 Associations of different asthma medication adherence scores with poor asthma control

4.3 Patients' beliefs about specific necessity and concerns about medicines associated with poor asthma control

4.4 The association between cognitive and emotional illness questionnaire and poor asthma control

4.5 Association of cognitive and emotional illness indicators and poor treatment adherence.

4.6 Association between medication beliefs and poor treatment adherence 52

5. DISCUSSION 55

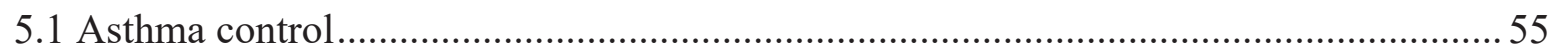

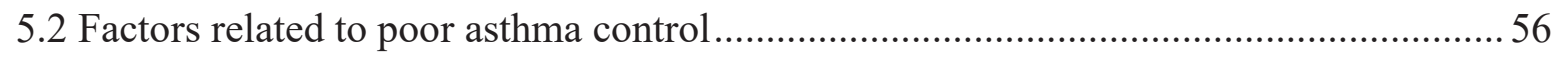

5.3 Prevalence of medical treatment adherence............................................................. 57

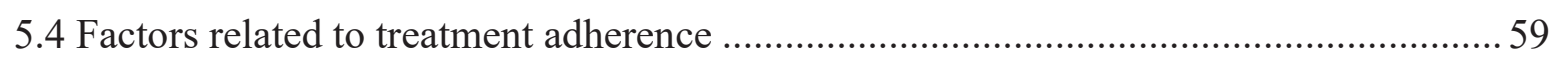

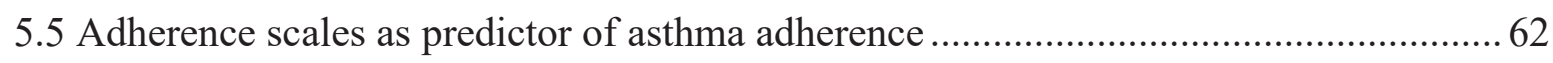

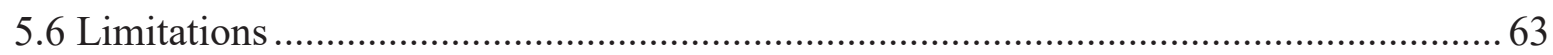

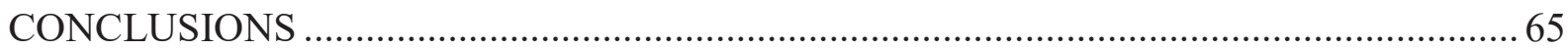

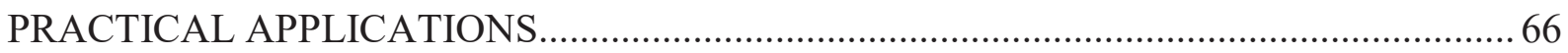

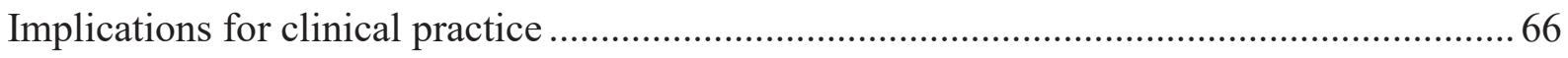

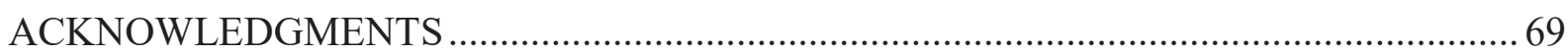

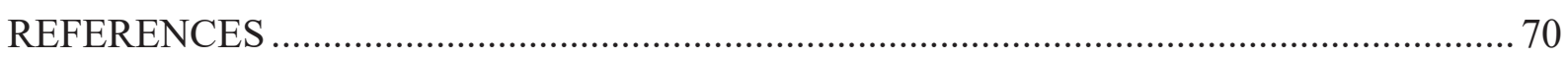

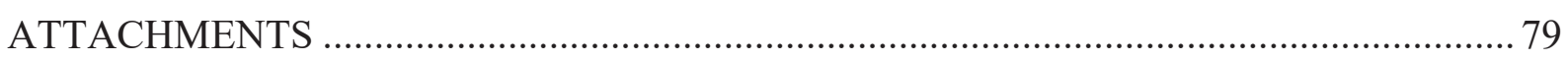

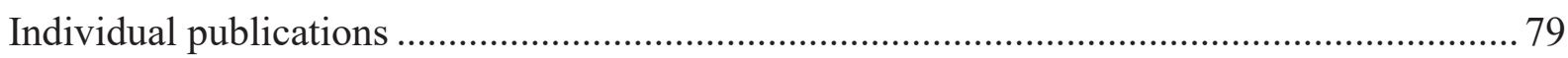




\section{ABBREVIATIONS}

ABC Ascertaining Barriers to Compliance

ACQ Asthma Control Questionnaire

ACT Asthma Control Test

AIRE Asthma Insights and Reality in Europe

AIRLA Asthma Insights and Reality in Latin America

AIRIAP Asthma Insights and Reality in Asia-Pacific

ALWC At Least Well Controlled

BMQ Beliefs about Medicines Questionnaire

CI Confidence interval

COPD Chronic Obstructive Pulmonary Disease

CSM Common-Sense Model of Self-Regulation

DAI Drug Attitude Inventory

ECRHS European Community Respiratory Health Survey

FEV1 Forced Expiratory Volume in 1 second

FVC Forced Vital Capacity

GINA Global Initiative for Asthma

GOAL Gaining Optimal Asthma Control

GP General practitioner

HIV Human Immunodeficiency Virus

ICS Inhaled Corticosteroids

INSPIRE International Asthma Patient Insight Research

IPQ Brief Illness Perception Questionnaire

JTFPP Joint Task Force Practice Parameter

MAQ Medication Adherence Questionnaire

MARS Medication Adherence Report Scale

MMAS Morisky Medication Adherence Scale

MMAS-8 Eight-Item Morisky Medication Adherence Scale

NAEPP National Asthma Education and Prevention Program

NHS National Health Service

NWC Not Well Controlled

OR Odds ratio

PACS Pharmacy Asthma Control Screening

PEF Peak Expiratory Flow

RCP3Q Royal College of Physicians' Three Question's Tool 
SEAMS Self-Efficacy for Appropriate Medication Use Scale

SPSS Statistical Package for the Social Sciences

UK United Kingdom

USA United States of America

WHO World Health Organization 


\section{INTRODUCTION}

\subsection{Introduction}

It has been estimated that approximately 300 million people are suffering from asthma worldwide (Reddel H. K., et al., 2015; Bousquet J., et al., 2010). This number is foreseen to increase by an additional 100 million in the next ten years resulting in 400 million people living with asthma by the end of 2025 (Reddel H. K., et al., 2015; Bousquet J., et al., 2010). The estimated prevalence of people living with asthma ranges from $1 \%$ to $21 \%$ in adults and with up to $20 \%$ of children aged 6-7 years experiencing severe wheezing episodes within a year (To T., et al., 2012; Lai C. K., et al., 2009).

The problem of nonadherence to the therapy is one of the main reasons of insufficient asthma control (Krishnan J. A, et al., 2004; Rabe K. F., et al., 2000; Rabe K. F, et al., 2004). Therefore, one of the main challenges in asthma control is adherence to pharmaceutical treatment. Generally, poor adherence is common across many chronic diseases such as asthma (Krishnan J. A, et al., 2004; Cerveri I., et al, 1999). Studies assessing treatment plans in asthma patients have revealed that adherence to medication range between 30 to $70 \%$ (Cerveri I., et al, 1999; Bender B. G., Bender S. E., 2005; Bender B. G., Long A., Parasuraman B., Tran Z. V., 2007). There is a common agreement that low treatment adherence explains in great parts the observed insufficient disease control in asthma patients in both Europe and worldwide as adequate asthma control requires the use of regular asthma medication (Reddel H. K., et al., 2015; Krishnan J. A, et al., 2004; Rabe K. F., et al., 2000; Rabe K. F, et al., 2004). The principal goal of asthma treatment is to achieve adequate asthma control in order to prevent disease progression and functional limitations that a patients experience due to their disease (Reddel H. K., et al., 2015; Braido F., 2013). In addition, good asthma control has been shown to improve quality of life in both children and adult patients (Katz P. P., Yelin E. H., Eisner M. D., Blanc P. D., 2002; Correia de Sousa J., et al., 2013; Benito-Fernández J., et al., 2013). Another area of concern to consider is the fact that expected effects of a pharmaceutical treatment are measured in a clinical trial setting that differs from the real life conditions. An important reason for such difference is patient non-adherence to treatment in the real-life setting.

The overall adherence process consists of prescribing the right treatment to the patient, filling the prescription in the hospital or pharmacy, taking the medicines following the prescription and continuing the treatment for its whole duration.

Several factors influence treatment adherence. Some of these factors are related to complexity of the therapy, fear of side effects of drugs, method of taking the drug, dosage 
regimen, adverse events, knowledge about the essence of the disease and its complications, illness perception and social support (Williams L. K., et al., 2004; Olszanecka-Glinianowicz M., Almgren-Rachtan A., 2014; Restrepo R. D., et al., 2009). Especially, medical beliefs, cognitive and emotional perceptions have been shown to be related to medical adherence (Unni E., Shiyanbola O. O., 2016; Chiu K. C., et al., 2014). Furthermore, individual asthma management might be improved by a better understanding of the types of beliefs or illness related perceptions that are associated with low adherence to preventer medication (Horne R., Weinman J., 2002). Preventer medication are medicines that supress the key pathogenic mechanism of asthma - chronic inflammation of airways. The most often used preventer medications for adult patients are inhaled corticosteroids in monotherapy or in combination with long acting beta 2 mimetic compounds. Patient's opinion about these medicines is influenced by the fact that the patient does not feel any immediate effect after medication use.

Evaluating the beliefs about asthma medication, cognitive and emotional perceptions may help to identify patients with poor adherence to treatment in clinical practice, gain understanding why they are non-adherent in order to provide additional attention in order to increase the likelihood of taking their asthma medication regularly.

One of the key roles of the healthcare professional is to adjust asthma treatment to reach and maintain optimal control. Generally, good control may also depend on several other factors such as individual's understanding of his disease, the necessity or concerns of the current treatment (Correia de Sousa J., et al., 2013; Benito-Fernández J., et al., 2013; Williams L. K., et al., 2004). However, there is limited evidence about associations between medication beliefs, illness perception and asthma control. The few studies that have assessed one of the abovementioned indicators were mainly conducted to test associations with treatment compliance related to specific medication such as corticosteroids but not with an outcome measure such as the disease control in general (Restrepo R. D., et al., 2009; Unni E., Shiyanbola O. O., 2016).

It is not easy to test clinically for adherence therefore several questionnaires have been developed to assess adherence to medication (Rabe K. F, et al., 2004; Cerveri I., et al, 1999). These questionnaires are widely used in many countries.

Scientific novelty of our research is based on the fact that a very limited information is available about treatment adherence and disease control of asthma patients in the Baltic countries and Latvia in particular. The primary research data are obtained by questionnaires and semantic specifics of local language play a role in research results. Also, cultural environment and specifics of the local healthcare setting - patient pathways, access to specialists and medicines might be impactful differentiators for patient beliefs and actions if compared to research performed in other countries. Furthermore, assessing how well medical beliefs, 
cognitive, emotional perceptions predict treatment adherence in the currently available adherence scores may give valuable insight in making a choice for a questionnaire-of-choice for the Latvian asthma population in order to be implemented in clinical practice throughout the country.

\subsection{Objectives and hypothesis}

\subsubsection{Study aim}

The aim of this study is to assess level of adherence and disease control in asthma patients in Latvia and patient factors associated with adherence to asthma treatment and control.

\subsubsection{Specific objectives}

I. To investigate whether sociodemographic and socio-economic factors (age, sex, education and income level) are associated with asthma control and asthma treatment adherence

II. To investigate whether patient's beliefs about specific necessity and concerns about medicines are associated with asthma control.

III. To investigate whether patient's beliefs about specific necessity and concerns about medicines are associated with treatment adherence to asthma medication.

IV. To study whether beliefs about asthma medication, cognitive and emotional factors are associated with asthma control.

V. To study whether beliefs about asthma medication, cognitive and emotional factors are associated with treatment adherence to asthma medication.

VI. To test the association between adherence to asthma medication and asthma control.

\subsubsection{Study hypothesis}

There is an association between beliefs about asthma medication, cognitive and emotional factors, illness perception, sociodemographic and socio-economic factors, adherence to medication and asthma control in Latvian asthma patients. Graphic model of the study hypothesis is shown in Picture 1. 


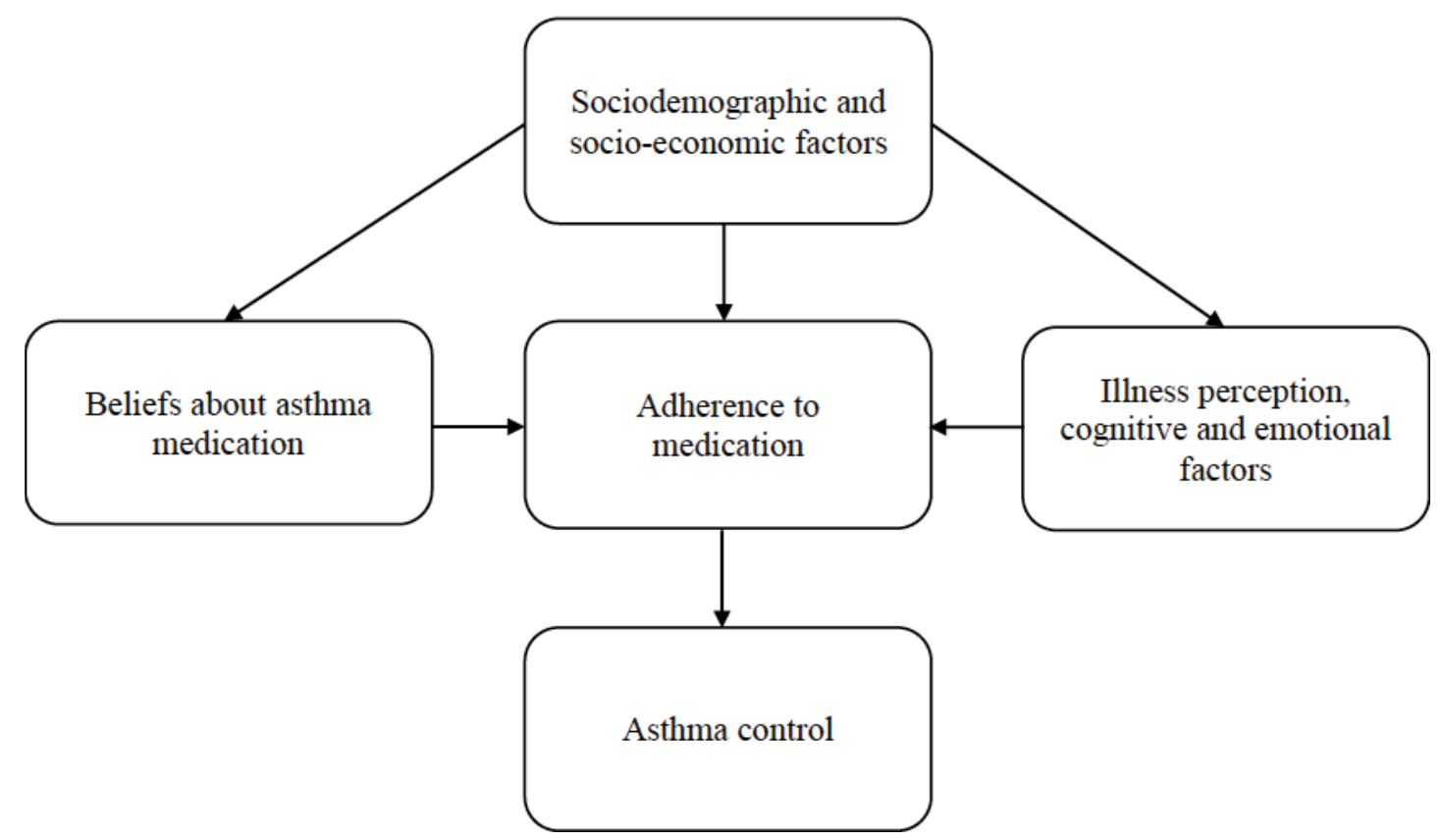

Figure 1.1 Graphic model of the study hypothesis 


\section{LITERATURE REVIEW}

\subsection{Introduction into asthma control}

Asthma is a disease characterized by chronic airway inflammation. The definition of asthma includes many different symptoms associated with airway hyper-responsiveness resulting in wheeze, shortness of breath, chest tightness and cough (Global Initiative for Asthma. Global Strategy for Asthma Management and Prevention, 2017). These symptoms usually vary over time and intensity leading to variable expiratory airflow limitation.

Asthma is a very serious disease that affects men, women and children on a global level. The estimated prevalence of asthma ranges from $1 \%$ to $21 \%$ in adults and up to $20 \%$ in children aged 6-7 (To T., et al., 2012; Lai C. K., et al., 2009). Although some countries have seen a decline in asthma-related hospitalizations and deaths the global burden for patients from exacerbations and day-to-day symptoms has increased by almost 30\% in the past 20 years (Lozano R., et al., 2010; Vos T., et al., 2010). Not only patients, but also by families, healthcare systems and society feel the burden related to asthma. Asthma is one of the most common chronic diseases affecting children and young adults, and there is increasing recognition of its impact upon working-age adults, the importance of adult-onset asthma, and the contribution of undiagnosed asthma to respiratory symptoms and activity limitation in the elderly (Reddel H. K., et al., 2015).

The principal goal of asthma treatment is to achieve adequate asthma control in order to prevent disease progression and functional limitations that a patient experiences due to his disease (Reddel H. K., et al., 2015; Braido F., 2013). In addition, good asthma control has been shown to improve quality of life in both children and adult patients (Katz P. P., Yelin E. H., Eisner M. D., Blanc P. D., 2002; Correia de Sousa J., et al., 2013; Benito-Fernández J., et al., 2013). Therefore, the main tasks of healthcare professionals are to establish each patient's current level of treatment and control and then to adjust treatment to reach and maintain optimal control (Braido F., 2013).

Asthma patients with moderate to severe disease need optimal treatment to avoid severe exacerbations. All current guidelines recommend combination therapy using an inhaled corticosteroid plus a long-acting beta- 2 agonist for patients insufficiently controlled by inhaled corticosteroids alone (Bousquet J., et al., 2007; Bateman E. D., et al., 2008). In addition, lung deposition is crucial for an optimal treatment of asthma. Inflammation of the small airways (internal diameter $<2 \mathrm{~mm}$ ) is an important feature of asthma and treatment of distal lung inflammation has been suggested to be key for appropriate asthma pharmacotherapy (Reddel H. K., et al., 2009). 
The level of asthma control is the extent to which the manifestations of asthma can be observed in the patient, or have been reduced or removed by treatment (Vos T., et al., 2012; Taylor D. R., et al., 2008). It is determined by the interaction between the patient's genetic background underlying disease processes, the treatment that they are taking, environment, and psychosocial factors (Taylor D. R., et al., 2008). Severe asthma may be defined as the requirement for high-intensity treatment (Taylor D. R., et al., 2008). Thus, asthma severity may be influenced by the underlying disease activity and by the patient's phenotype, both of which may be further described using pathological and physiological markers. Taylor et al further proposed that these markers can also act as surrogate measures for future risk (Taylor D. R., et al., 2008).

Both asthma severity and asthma control can be broken down into two domains: impairment and risk. Impairment is an assessment of the frequency and intensity of symptoms and functional limitations that a patient is experiencing or has recently experienced. Risk is an estimate of the likelihood of either asthma exacerbations or of progressive loss of pulmonary function over time. Optimal control includes the frequency and intensity of symptoms and functional limitations that a patient experiences or has recently experienced as a consequence of asthma and includes measures of day and night symptoms, use of reliever therapy, activity limitations, and lung function (Braido F., 2013). Lung function is an important part of the assessment of future risk. It should be measured at the start of the treatment, after 3-6 months of treatment in order to identify the patient's personal best, and periodically thereafter for ongoing risk assessment (Global Initiative for Asthma. Global Strategy for Asthma Management and Prevention, 2017). The period for which current clinical control should be assessed is proposed to be the previous 2 to 4 weeks for adults and at least 4 weeks for children. The test most used for assessing the risk of future adverse events is spirometry, especially forced expiratory volume in 1 second (FEV1) expressed as a percent of the predicted value or as a proportion of the forced vital capacity (FVC) or FEV1/FVC.

However, asthma control not only consists of achieving current clinical control or current extent of impairment, but also of minimizing future risk to the patient by ensuring the absence of asthma exacerbations, the prevention of accelerated decline in lung function over time, and absence of side effects due to medications (Taylor D. R., et al., 2008; NAEPP (National Asthma Education and Prevention Program)). These two components have been particularly emphasized in the Expert Panel Report 3 of the National Heart, Lung, and Blood Institute in terms of current impairment and future risk (Taylor D. R., et al., 2008).

Several studies have demonstrated that the use of healthcare resources, the level of lifestyle impairment, and quality of life are all strictly linked to the level of asthma control: the 
better the control, the less impairment, the lower the use of healthcare resources, and the higher the quality of life (Bateman E. D., et al., 2007; Chapman K. R., Boulet L. P., Rea R. M., Franssen E., 2008; Vollmer W. M., et al., 2002; Vollmer W. M., et al., 1999; Sullivan S. D., et al., 2007; Sullivan S. D., et al., 2007; Schatz M., et al., 2005; Chen H., et al., 2007; Weiss K., et al., 2006). A study assessing approximately 4000 patients with difficult-to-treat or severe asthma showed that patients with uncontrolled asthma had a statistically significant higher annual mean number of work days lost, school days lost, and physician visits compared with patients who had controlled asthma (Sullivan S. D., et al., 2007). Furthermore, the costs related to asthma management for uncontrolled patients were twice the costs compared with controlled patients. In agreement with their findings, the study by Chapman et al found that poor daily control was associated with more hospitalizations, emergency and unscheduled visits, and other healthcare contacts in approximately 10,500 patients presenting in general practices in Canada (Chapman K. R., Boulet L. P., Rea R. M., Franssen E., 2008). In addition, compared with patients with controlled asthma, those with uncontrolled asthma were at higher risk for limitations in outdoor or physical activity and a $66 \%$ increased risk of daily activity limitations (Haselkorn T., et al., 2010).

\subsection{Assessment of asthma control}

Braido et al proposed that asthma treatment should aim at achieving and maintaining disease control for prolonged periods, with a minimum amount of medications, with due regard to the tolerability of treatment, potential for side effects, and costs (Braido F., 2013).

In general, symptoms such as wheeze, chest tightness, shortness of breath and cough, vary in frequency and intensity in asthma patients (McCoy K., et al., 2006; Meltzer E. O., et al., 2011; Schatz M., et al., 2012). Poor symptom control has shown to be associated with an increased risk of asthma exacerbations (McCoy K., et al., 2006; Meltzer E. O., et al., 2011; Schatz M., et al., 2012). Therefore, the current recommendations in clinical practice is to assess asthma control at every given opportunity. It is important to ask the patients directly about the frequency and severity of their symptoms. Acceptability of symptoms may differ among asthma patients (McCoy K., et al., 2006; Meltzer E. O., et al., 2011).

It is not always possible to get spirometry tests conducted in all asthma patients in primary health-care practices and in case it is, these tests are time-consuming. Therefore, several screening tools for assessing asthma control have been developed and validated for use in primary health-care setting. However, no classification or strict guidelines for use of such tools has been universally accepted. These tools can be used in primary health care to identify 
quickly patients who need more detailed assessment of their disease control. We may divide the existing screening tools into three main categories: (i) simple screening tools; (ii) categorical symptom control tools; and (iii) numerical asthma control assessment tools.

\subsubsection{Simple screening tools}

The most widely disseminated asthma treatment guidelines, those of the Global Initiative for Asthma (GINA) developed a consensus-based GINA symptom control tool (Global Initiative for Asthma. Global Strategy for Asthma Management and Prevention, 2017). The GINA was developed based on expert opinion and includes six main characteristics such as daytime symptoms, limitations of activities, nocturnal symptoms/awakenings, the need for reliever/rescue treatment, lung function peak expiratory flow or forced expiratory volume in 1 second, and exacerbations. According to the answers provided, the patient is classified into controlled, partially controlled or uncontrolled. If a patient has none of each of the six items, he has controlled asthma according to GINA. If a patient has up to three of the items, their asthma is partially control. In case of three or more features of partially controlled asthma present in any week or at least one exacerbation in any week, the patient's asthma is regarded uncontrolled.

Other simple screening tools are the Pharmacy Asthma Control Screening tool (PACS) and the 30-second Asthma Test which also includes time off work/school (LeMay K. S., Armour C. L, Reddel H. K., 2014; Ahmed S., Ernst P, Tamblyn R, Colman N., 2007). The PACS tool is based on asthma guidelines and is used by community pharmacists in Australia to assess patients' asthma status (National Asthma Council Australia. Asthma management handbook, 2002). The PACS includes five items that are used to define whether the patient has good, partial or poor asthma control. These items include symptoms of asthma, waking at night due to asthma, chess tightness on waking, difficulties in performing vigorous and moderate physical activities. A multi-center randomized controlled implementation trial of a comprehensive pharmacy-based asthma program has recently evaluated the performance of PACS (Armour C. L., et al., 2011; Armour C. L., et al., 2013).

The 30-second Asthma Test was developed based on the clinical symptoms outlined in the asthma guidelines in Canada (Ernst P., Fitzgerald J. M., Spier S., 1996). The test includes information on daytime symptoms, night-time symptoms, use of rescue bronchodilators, limitations in physical activity and missed school or work.

Composite scoring systems are not necessarily suitable for primary care contexts such as community pharmacy or general practice where there are substantial pressures on clinicians' 
time. For such settings, there is considerable interest in brief screening questionnaires that can rapidly identify patients for whom more detailed assessment is needed. Therefore, the main advantage of simple asthma control screening tools are that they can be easily used to guide treatment decisions in clinical practice.

\subsubsection{Categorical symptom control tools}

Some examples of categorical symptom control tools are the consensus-based Royal College of Physicians (RCP3Q) Three Questions' tool and the Gaining Optimal Asthma Control (GOAL) scale (Pinnock H., et al., 2012; Bateman E. D., et al., 2004). The RCP3Q emerged from a UK consensus meeting of representatives of primary and secondary care and patient organizations as a clinical tool which 'made sense to both clinician and patient' and would be 'widely used to improve standards of care (Pearson M. G. and Bucknall C. E., 1999; Georgiou A., Pearson M., 2002). Precursors of the RCP3Q (the Tayside Asthma Stamp and the Jones morbidity index) had been used in audits of asthma management by postal questionnaire to predict asthma exacerbations and during telephone consultations to screen for patients who might benefit from a face-to-face review in the United Kingdom (Hoskins G., Williams B., Jackson C., Norman P., Donnan P., 2011; Jones K. P., Bain D. J. G, Middleton M., Mullee M. A., 1992; Jones K. P., et al., 1992; Gruffydd-Jones K., Hollinghurst S., Ward S., Taylor G., 2005). The RCP includes information on difficulty sleeping, daytime symptoms and activity limitation due to asthma in the previous months.

The definitions of control in the GOAL scale were derived from the treatment goals of the Global Initiative for Asthma/National Institutes of Health guidelines: "totally controlled" or "well controlled" or uncontrolled - if neither definition was fulfilled (National Asthma Education and Prevention Program, 1997; Global Initiative for Asthma (GINA), 1998). Both control definitions were composite measures that included the following asthma outcomes: $\mathrm{PEF}$, rescue medication use, symptoms, night-time awakenings, exacerbations, emergency visits, and adverse events. Equal weighting was given to each criterion (Bateman E. D., et al., 2004). Totally controlled and well-controlled weeks were defined by achievement of all of the specified criteria for that week. Totally controlled asthma was achieved if the patient, during the eight consecutive assessment weeks, recorded seven totally controlled weeks and had no exacerbations, emergency room criteria, or medication-related adverse event criteria for each day of each week. Well-controlled asthma was achieved if the patient recorded 7 of 8 well-controlled weeks, and failure to achieve any one of these would result in failure to achieve control for that week. Failure of the exacerbation, emergency visit, or adverse event criteria 
resulted in the automatic failure of control status (totally and well-controlled definitions) for the entire 8-week period, irrespective of how well asthma was controlled at other time points during the 8 weeks. Well-controlled asthma was similarly assessed over 8 weeks but was allowed a low level of symptoms and rescue medication use.

\subsubsection{Numerical asthma control tools}

Numerical asthma control tools provide scores and cut points to distinguish different levels of symptom control, validated against health-care provider assessment allowing to quantify asthma control. These scores may be useful for assessing patient progress. These scores may be useful for assessing patient progress. Numerical asthma control tools are also used in clinical research. The two most commonly used numerical asthma control tools are the Asthma Control Questionnaire (ACQ) and the Asthma Control Test (ACT) (Juniper E. F., et al., 1999; Juniper E. F., Svensson K., Mörk A. C., Ståhl E., 2005; Thomas M., 2009; Juniper E. F., et al., 2006; Nathan R. A., et al., 2004; Schatz M., et al., 2009). Both the ACQ and the 5-item ACT, have been developed and validated in a range of populations against physician assessment of asthma control and guideline-based classifications (Juniper E. F., et al., 1999; Juniper E. F., Svensson K., Mörk A. C., Ståhl E., 2005; Thomas M., 2009; Nathan R. A., et al., 2004; O'Byrne P. M., et al., 2010). Moreover, the ACQ and ACT have been recommended as core outcomes for clinical research by the American Thoracic Society/European Respiratory Society Task Force on Assessment of Asthma Control and Exacerbations and the NIH Asthma Outcomes Workshop (Reddel H. K., et al., 2009; Cloutier M. M., et al., 2012). The ACQ was developed using expert opinion and originally contained seven items; however, a five-item version (ACQ-5) has been validated for use in clinical trials and epidemiological surveys (Juniper E. F., O’Byrne P. M., Roberts J. N., 2001). The ACQ development involved ninety-one asthma clinicians who were members of international asthma guidelines. They identified the seven items in the tool as being the most relevant for determining asthma control. Patients are asked to recall their experiences during the previous week and to answer to the first six questions (nighttime waking, symptoms on waking, activity limitation, shortness of breath, wheeze, and rescue short-acting $\beta 2$-agonist use) on a 7-point Likert scale ( $0=$ no impairment; 6 = maximum impairment). Clinic staff score FEV1 predicted bronchodilator use on a similar 7-point scale. The items are equally weighed and the ACQ score is the mean of the seven items and therefore between 0 (well controlled) and 6 (extremely poorly controlled). Three shortened versions (symptoms alone, symptoms plus FEV1, and symptoms plus short-acting $\beta 2$ agonists use have since also been validated. All four versions of ACQ have demonstrated reliability, 
validity, and sensitivity to change, with even the smallest change in score of 0.5 considered to be a clinically significant improvement or deterioration in disease control. Developmental studies have established the cut-off points for controlled asthma $(<0.75$ points $)$ and not well-controlled asthma ( $>1.5$ points).

The ACT was developed and validated to offer a patient-based tool for identifying patients with poorly controlled asthma over the previous 4 weeks. Nathan et al administered a 22-item survey to 471 patients with asthma in the offices of asthma specialists (Nathan R. A., 2004). Furthermore, they collected information on the specialist's rating of asthma control after

spirometry. Stepwise regression methods were then used to select a subset of items that showed the greatest discriminant validity in relation to the specialist's rating of asthma control. Internal consistency reliability was computed, and discriminant validity tests were conducted for ACT scale scores. In the end, five items were selected from regression analyses. These five items included information on limitations at work or school due to asthma, the presence of daytime or nighttime symptoms, the use of rescue medications, and the subjective perception of the level of asthma control during the previous four weeks. The sum of the scores allows asthma control to be categorized as follows: non-controlled asthma (5-19 points), controlled asthma (20-24 points), and optimal disease control (25 points). The internal consistency reliability of the 5-item ACT scale was 0.84. ACT scale scores discriminated between groups of patients differing in the specialist's rating of asthma, the need for change in patient's therapy, and percent predicted FEV1. As a screening tool, the overall agreement between ACT and the specialist's rating ranged from $71 \%$ to $78 \%$ depending on the cut points used The area under the receiver operating characteristic curve was 0.77 .

\subsubsection{Comparison of different asthma control tools}

The correlations between the international guidelines by GINA and the questionnaires' rating of asthma control has been explored in several studies, highlighting some discrepancies. A study by Sastre and coworkers confirmed that ACQ is a precise tool in a real-life setting and reveals differences in cut-off points used by three versions of the questionnaire (Sastre J., et al, 2010). The optimal cutoff to distinguish between patients with well-controlled asthma and those in whom asthma is uncontrolled was a score of 1.14; lower than the score suggested by Juniper. O'Bryne et al. demonstrated the similarity between classification of asthma control as defined by GINA and GOAL (O'Byrne P. M., et al., 2010). The differences that do exist are in the descriptions of controlled GINA and totally controlled GOAL asthma, where slightly more symptoms and rescue b2-agonist use are permitted by GINA, and in the descriptions of the 
intermediate categories of partly controlled GINA and well-controlled GOAL asthma where, again, GINA is less stringent (O'Byrne P. M., et al., 2010). The classification of the GINA has shown to correlate well with several numeric asthma control scores (Thomas M., et al, 2009; O'Byrne P. M., et al., 2010). O'Byrne et al. showed that the percentages of patients considered by GINA criteria to have controlled and partly controlled asthma and by the GOAL criteria to have totally controlled and well-controlled asthma are comparable to an ACQ score of $<1.00$ (O'Byrne P. M., et al., 2010). Thomas et al compared asthma control measured by the GINA criteria and the ACT in almost 3,000 asthmatic patients attending primary care in in France, Germany, Italy, Spain, the UK, and the USA (Thomas M., et al., 2009). An ACT score of at least 20 predicted GINA-defined controlled asthma 51\% of the time, while a score of less or equal than 19 predicted partly controlled or uncontrolled asthma in $94 \%$ of the cases (Thomas M., et al., 2009). Similar results were found comparing GOAL criteria with the ACQ (Juniper E. F., 2006). For all the ACQ versions, the crossover point between well controlled and not well controlled is close to 1.00. More precisely, if a patient reports an ACQ score of 0.75 or less, there is an $85 \%$ chance that his asthma is well-controlled and if a patient has an ACQ score of 1.50 or greater, there is an $88 \%$ chance that his asthma is not well-controlled. An ACT score of $<19$ correctly predicted GINA "partly controlled" or "uncontrolled" asthma $94 \%$ of the time overall and $>93 \%$ of the time in each country and ACT score $>20$ predicted GINA-defined controlled asthma $51 \%$ of the time. Another study investigated three different guideline-based tools (GINA, the National Asthma Education and Prevention Program NAEPP - and the Joint Task Force Practice Parameter - JTFPP) against the ACQ and ACT. Despite having 4 of 5 tested domains in common, the ACQ and ACT showed only moderate agreement with each other. The high level of agreement among the NAEPP, the JTFPP, and GINA should be expected given the similarity in definitions of controlled asthma. The agreement between the ACQ or ACT and the other clinical tools was fair (Khalili B., Boggs P. B., Shi R., Bahna S L., 2008). Recently, Miedinger and coworkers found that an ACT cut-off score of $\leq 17$ best identified uncontrolled asthma according to GINA guidelines (Miedinger D., et al., 2011).

The PACS have been validated as well (LeMay K. S., Armour C. L, Reddel H. K., 2014). When the performance of the PACS tool was evaluated against the ACQ, PACS poor control had good sensitivity for identifying patients with not well-controlled asthma (ACQ $\geq 1.0$ ). The baseline value when most patients had poorly-controlled asthma was 0.92 and after a six-month pharmacy asthma management program that value decreased to 0.76 when there was a broader distribution of asthma control (LeMay K. S., Armour C. L, Reddel H. K., 2014; Juniper E. F., Svensson K., Mörk A. C., Ståhl E., 2005). However, agreement between 
change in the two assessments was only fair, and many patients who were still classified by PACS as having poor control at the end of the study nevertheless had achieved a clinically important improvement in ACQ score since enrolment (LeMay K. S., Armour C. L, Reddel H. K., 2014; Juniper E. F., Svensson K., Mörk A. C., Ståhl E., 2005).

Several studies validated the 30 Second Asthma Test (Nathan R. A.,, 2004; Boulet L. P., Phillips R., O’Byrne P., Becker A., 2002; Fabbri L. M., Boulet L. P., Kardos P., Vogelmeier C., 2004). There was support for the validity of The 30 Second Asthma Test, which performed as expected in relation to specialist ratings, $\mathrm{FEV}_{1}$ (control) and change in intensity of therapy. A cut-off score of two or higher was an indication of poor control as evidenced by the sensitivity analysis. The patient ratings corresponded better with specialist ratings than $\mathrm{FEV}_{1 \text { (control) }}$ estimates, which is in keeping with other studies. Thirty-four per cent of patients had more than two symptoms on The 30 Second Asthma Test but were classified as in control according to FEV1 (control).

\subsection{Prevalence of good asthma control}

Guideline-defined asthma control can be attained and maintained for the majority of patients in controlled research settings, but current evidence indicates that many asthmatic patients do not achieve an acceptable asthma control in real-life clinical practice. Despite advances in asthma treatment and in the implementation of guidelines for asthma management, the disease remains poorly controlled, in most countries (Rabe K. F., et al., 2000; Rabe K. F., et al., 2004; Lai C. K. W., et al., 2003; Neffen H., et al., 2005; Adams R. J., et al., 2002; Cazzoletti L., et al., 2007; Partridge M., van der Molen T., Myrseth S. E., Busse W. W., 2006; Demoly P., et al., 2009; Allegra L., et al., 2012; Fueyo A., et al., 2007; Yildiz F., 2013; Su N., et al., 2013).

The Asthma Insights and Reality in Europe (AIRE) survey was the first comprehensive, multinational survey assessing the level of asthma control as reported by patients, which partly reflect the extent to which guideline recommendations are implemented (Rabe K. F., et al., 2000). Asthma patients were identified by telephone by screening 73,880 households in seven European countries (France, Germany, Italy, The Netherlands, Spain, Sweden, and UK). Designated respondents were interviewed on healthcare utilization, symptom severity, activity limitations and asthma control. Asthma patients were identified in 3,488 households, and 2,803 patients completed the telephone interview using a structured questionnaire. The results showed that $46 \%$ of patients reported daytime symptoms and 30\% asthma-related sleep disturbances at least once a week. Within the last year of the study, 25\% underwent unscheduled urgent care 
visits, $10 \%$ had one or more emergency room visits and $7 \%$ had overnight hospitalization due to asthma. Only $5.3 \%$ of the population surveyed met all the goals of the GINA guidelines (Global Initiative for Asthma, 2017). Rabe et al concluded that the current level of asthma control in Europe fell far short of the goals for long-term asthma management. Patients' perception of asthma control is different from their actual asthma control (Rabe K. F., et al., 2000).

Similarly, the Asthma Insights and Reality in Asia-Pacific (AIRIAP) examined asthma symptoms, health care use, and management in the Asia-Pacific region and whether asthma management met the goals proposed by the GINA guidelines in children and adults (Lai C. K. W., et al., 2003). The AIRIAP revealed in a population sample of 3207 respondents with physician-diagnosed asthma that also in the Asia-Pacific region asthma control is far from optimal. More than $50 \%$ of asthma patients reported daytime symptoms, $44 \%$ had night awakenings due to asthma symptoms during the last four weeks, and 45\% patient's experienced limitations in physical activity. Moreover, $27 \%$ of adults and $37 \%$ of children reported work or school absence in the past year. A high percentage of asthma patients (44\%) had been hospitalized or had made unscheduled emergency, unplanned visits due to acute asthma exacerbations during the previous 12 months.

The Asthma Insights and Reality in Latin America (AIRLA) survey in 2003 was the first to analyze the quality of treatment and asthma control in Latin America (Neffen H., et al., 2005). AIRLA assessed the health care utilization, the severity of symptoms, activity limitations, and medication use in 2184 asthmatic adults or parents of asthmatic children (under 16 years old) from 11 LA countries (Argentina, Brazil, Chile, Colombia, Costa Rica, Ecuador, Mexico, Paraguay, Peru, Uruguay and Venezuela. The results revealed that daytime asthma symptoms were reported by $56 \%$ of the respondents, and $51 \%$ reported being awakened by their asthma at night. More than half of those surveyed had been hospitalized, attended a hospital emergency service or made unscheduled emergency visits to other healthcare facilities for asthma during the previous year. Moreover, self-reported perception of asthma control did not match symptom severity, even in patients with persistent severe asthma. $45 \%$ of whom regarded their disease as being well or completely controlled. Only $2 \%$ (2\% adults and $3 \%$ children) met all criteria for asthma control according to the GINA (Global Initiative for Asthma, 2017). Although $37 \%$ reported treatment with prescription medications, only $6 \%$ were using inhaled corticosteroids. Most adults (79\%) and children (68\%) reported that asthma symptoms limited their activities. Absence from school and work was reported by $58 \%$ of the children and $31 \%$ of adults, respectively. 
In 1998, Adams et al carried out a large national population survey in the Unites States in order to describe the current use of asthma medication in the United States population and to examine the influence of symptoms and socio-demographics on medication use (Adams R. J., et al., 2002). His study revealed that the use of appropriate asthma therapy remains inadequate in the United States. The use of anti-inflammatory medication was reported by $20 \%$. Of these, most were using inhaled corticosteroids (73\%), with use of antileukotrienes reported by $11 \%$ and use of cromolyn-nedocromil reported by $19 \%$. Of persons with persistent asthma symptoms in the past month, $26 \%$ reported current use of some form of anti-inflammatory medication. In bivariate analysis persons reporting lower income, less education, and present unemployment, as well as smokers, were significantly less likely to report current anti-inflammatory use than were other populations.

In 2004, a cross-sectional household survey was carried out in 29 countries in North America, Europe, and Asia identifying from the general population asthmatic patients with symptoms within the last year or who were taking current asthma medication (Rabe K. F., et al., 2004). A standard questionnaire was administered to 7786 adults and 3153 children with asthma. The survey aimed at determining international variations in the severity, control, and management of asthma in children and adults. A significant proportion of patients continue to report symptoms and lifestyle restrictions and to require emergency care. The use of anti-inflammatory preventative medication, even in patients with severe persistent asthma, was low, ranging from $26 \%$ in Western Europe to $9 \%$ in Japan. Accordingly, the surveys showed that asthma limits the normal activities of a considerable proportion of patients, ranging from $17 \%$ in Japan to $68 \%$ across Central and Eastern Europe. Thus, despite the availability of effective therapies, with long-term management falling far short of the goals set in the GINA guidelines (Global Initiative for Asthma, 2017).

The European Community Respiratory Health Survey II carried out during 1999-2002 found that a major proportion of European adults with asthma were poorly controlled and that the majority of them were receiving suboptimal antiasthma therapy (Cazzoletti L., et al., 2007). Almost nine out of ten adult asthma patients who had used inhaled corticosteroids (ICS) in the last 12 months were not able to achieve total control of the disease. Half of them had uncontrolled asthma and 36\% had partly controlled asthma. Among those who had not used ICSs in the last 12 months, $18 \%$ had uncontrolled and 36\% had partly controlled asthma.

The International Asthma Patient Insight Research (INSPIRE) study examined the attitudes and actions of 3415 physician-recruited adults aged $>$ or $=16$ years with asthma in eleven countries who were prescribed regular maintenance therapy with inhaled corticosteroids or inhaled corticosteroids plus long-acting beta2-agonists (Partridge M., van der Molen T., 
Myrseth S. E., Busse W. W., 2006). Close to 3,400 treated asthma adults were interviewed by phone using a structured questionnaire. Despite being prescribed regular maintenance therapy, $74 \%$ of patients used short-acting beta2-agonists daily and 51\% were classified by the Asthma Control Questionnaire as having uncontrolled asthma. Even patients with well-controlled asthma reported an average of six worsenings per year. The mean period from the onset to the peak symptoms of a worsening was 5.1 days. Although most patients recognized the early signs of worsening, the most common response was to increase short-acting beta2-agonist use; inhaled corticosteroids were increased to a lesser extent at the peak of a worsening.

The purpose of the European National Health and Wellness Survey was to evaluate the level of asthma control 10 years after the publication of the GINA guidelines in five European countries (France, Germany, Italy, Spain, and the UK). ${ }^{78}$ Data were obtained from 37,476 adults in France, Germany, Italy, Spain and the UK. Analysis was limited to 2,337 respondents who self-reported a physician diagnosis. Based on the Asthma Control Test (ACT), respondents were grouped as ALWC (ACT $\geq 20$ ) and NWC (ACT $\leq 19)$. Nearly $80 \%$ of asthma sufferers were treated and 50\% of asthma sufferers were "not well controlled." Among those who were treated, 55\% remain not well controlled compared with 95\% in the AIRE study (Rabe K. F., et al., 2000). While these results seem to indicate an improvement in the level of control since the AIRE study, they also highlighted the disparity between available treatment options and the lack of adequate management.

The PRISMA study was designed to include a cross-sectional phase and a 12-month prospective phase with the aim to evaluate the level of asthma control in real life and its evolution during a 1-year follow-up (Allegra L., et al., 2012). A total of 2853 adult patients were recruited in 56 Hospital Respiratory Units in Italy. At baseline 64\% of patients had controlled asthma, 16\% partly controlled asthma, and 19.8\% were uncontrolled. The number of patients requiring hospitalization or unscheduled visits was lower in controlled than in partly controlled and uncontrolled patients. Also, good asthma control seemed to be more difficult to achieve in asthmatic adults who had used corticosteroids in the last 12 months compared with those who were not in need of inhaled corticosteroids (Fueyo A., et al., 2007).

A recent prospective study carried out in Turkey in 572 adult patients with persistent asthma revealed an asthma control rate of $61.5 \%$ in adult outpatients, which increased upon each follow-up, regardless of the smoking and educational and employment status of the patients (Yildiz F., 2013). Fixed dose combinations resulted superior in the achievement of asthma control. However, poor asthma control was associated with the incidence of comorbid diseases. The authors therefore advocated regular patient monitoring and patient education to 
raise awareness and therapeutic expectations, in order to better implement asthma management guidelines and achieve an optimal control of the disease.

A multi-center, cross-sectional study analyzed information on 3000 asthma outpatients from 36 general hospitals located in 10 large Chinese cities in 2008 (Vos T., et al., 2012). In total, $29 \%$ and $4 \%$ of the respondents had achieved control or partial control of their asthma, respectively, while for $26 \%$ of patients' asthma remained uncontrolled. Discussing the results of this large survey, the authors underlined that despite some improvement that had been achieved in asthma control level, a large gap remained between what had been reached and what was expected to be achieved in developed countries according to the current asthma guidelines.

\subsection{Factors related to asthma control}

Several factors have shown to be associated with poor control in asthma patients. These factors include among others lifestyle or behavioral factors, beliefs about illness and treatment, self-management of asthma, treatment adherence, presence of comorbidities and inhaler techniques. Other factors may be inadequate self-care training, health beliefs that compete with medical advice, insufficient rates of routine primary care, and restricted ability or motivation to manage one's own environmental (George M., Keddem S., Barg F. K., Green S., Glanz K., 2015).

A study among approximately 3000 Italian asthma patients revealed that the main reasons for poor control were low adherence to treatment ( $43 \%$ of all patients), exposure to irritants/triggers (29\%), unsatisfactory patient-doctor communication (21\%) and inadequate prescribed therapy (20\%) (Allegra L., et al., 2012). Moreover, uncontrolled patients were older, had lower education levels, and were more likely to be obese, depressed, and smokers, when compared to those considered to have controlled asthma. Another study in Spanish asthma patients showed that the main reasons for lack of asthma control, as declared by physicians, were comorbidities (in 36\% of patients), continued exposure to irritants/triggers in $34 \%$, and inadequate adherence to treatment (27\%) (Fueyo A., Ruiz M. A., Ancochea J., Guilera M., Badia X., 2007). These results were in line with a Turkish study where the presence of asthma-related comorbidity had a significantly negative effect on asthma control (Yildiz F., 2013). In addition, in agreement with previous studies, controlled patients, compared to partly controlled and uncontrolled, were more often nonsmokers $(59.4 \%)$, with a later onset of the disease $(65.6 \%)$ and atopic $(72.4 \%)$. 
Thus, smoking is most likely the most important lifestyle habit related with poor asthma control (Thomson N. C., Chaudhuri R., 2009; McLeish A. C., Zvolensky M. J., 2010; Haughney J., et al., 2008). There sufficient scientific evidence to conclude that concurrent smoking adversely impacts asthma control. The prevalence of current smoking among patients with asthma varies by country from $15 \%$ to $25 \%$ (Annesi-Maesano M. P., Oryszczyn C., Raherison, et al., 2004; Hylkema M. N., Sterk P. J., de Boer W. I., Postma D. S., 2007). In a retrospective cohort study of a large UK general practice database, current smokers were almost three times more likely than non-smokers to be hospitalized for their asthma over a 12-month period (Price D., Zhang Q., Kocevar V. S., Yin D. D., Thomas M., 2005). Inadequate controlled in smoking asthma patients may be the result of concomitant COPD or asthma misdiagnosed as COPD. An alternative explanation is that ICS therapy fails more often in smokers compared with non-smokers. Studies of smokers with asthma indicate that these patients respond differently to corticosteroids than do non-smokers (Annesi-Maesano M. P., Oryszczyn C., Raherison, et al., 2004; Hylkema M. N., Sterk P. J., de Boer W. I., Postma D. S., 2007).

In a study conducted among Dutch asthma patients, the effect of ICS was compared with placebo, using lung function and airway hyper-responsiveness as primary outcome variables (Kerstjens H. A., et al., 1993). They showed that a highly significant improvement in $\mathrm{FEV}_{1}$ was found in the study group treated with ICS compared with placebo. However, when the patients were stratified according to smoking status, benefits were noted only in the nonsmoking group. Chalmers et al further provided evidence in regard the lack of effects of ICS for treating patients with asthma who smoke. In their study, patients with mild asthma, fluticasone had no effect on lung function or sputum eosinophils in smokers (Chalmers G. W., et al., 2002). Eosinophil and neutrophil activity in smokers was not reduced by ICS therapy, even at high doses (Pedersen B., Dahl R., Karlstrom R., Peterson C. G, Venge P., 1996). Moreover, the correlation between exhaled nitric oxide, a marker of eosinophilic airway inflammation, and airway hyper-responsiveness was lost in smokers (Verleden G. M., Dupont L. J., Verpeut A. C., Demedts M. G., 1999). Administration of high-dose ICS therapy did not improve lung function among smokers with asthma in one study (Pedersen B., Dahl R., Karlstrom R., Peterson C. G, Venge P., 1996; Tomlinson J. E., et al., 2005).

The most important co-morbidity related to asthma control is allergic and non-allergic rhinitis. Asthma and rhinitis share a similar epidemiology (most patients with asthma have rhinitis), and they have common triggers (Bousquet J., Khaltaev N., et al., 2008; Thomas M., 2006; Leynaert B., 1999). The physiological pattern of inflammation is similar, involving $\mathrm{T}$ helper type 2 cells, mast cells, and eosinophils. In addition, nasal challenge results in 
asthmatic inflammation and vice versa (Corren J., Adinoff A. D., Irvin C. G., 1992; Braunstahl G. J., et al., 2000). Finally, the presence of rhinitis predicts the development of asthma (Leynaert B., 1999). Asthma patients with rhinitis use more health-care resources than those without rhinitis, indicating that their asthma is less well-controlled. In a retrospective cohort study of 27,000 adult patients with asthma included in a large UK general practice database, patients with concomitant rhinitis were 50\% more likely to be hospitalized for their asthma, and significantly more likely to visit their primary care physician, over a 12-month period than those without rhinitis (Price D., et al., 2005). Moreover, the presence of concomitant rhinitis was associated with significantly higher drug use and costs among these patients with asthma.

For children in a similar study, the presence of concomitant asthma and rhinitis more than doubled the likelihood of being hospitalized and significantly increased the likelihood of a physician visit for asthma (Thomas M., et al., 2005). All levels of rhinitis can impact on asthma control: the percentage of adult patients with poor asthma control is greater even among those with mild rhinitis, as compared with patients with asthma alone. Yildiz et al also showed that higher scores of ACT and higher likelihood of asthma control were linked with a lesser number of comorbidities supporting the evidence that various comorbid conditions such as rhino-sinusitis, psychological disturbances, and respiratory infections, are often observed in asthmatic patients (Yildiz F., 2013).

There is a strong influence of beliefs about illness and treatment on self-management of asthma (Horne R., 2006). Previous studies have shown that individuals with asthma who believe that their medication is necessary for their present and future health or that it prevents exacerbation of their disease are more likely to have their asthma well controlled (George M., et al., Axelsson M., Ekerljung L., Lundbäck B., 2015). In contrast, individuals who are concerned about their asthma medication are more inclined to deviate from the prescribed treatment (Horne R., Weinman J., 2002; Menckeberg T. T., et al., 2008; Ponieman D., et al., 2009).

Patients often make treatment choices according to their own understanding and beliefs about the illness and treatment (Horne R., et al., 2007). Patients' adherence to medication is particularly influenced by the way in which they evaluate their personal need for medication relative to their concerns about potential negative effects of taking it (Horne R., et al., 2007; Horne R., Weinman, J., 1999). A recent Australian study indicated that personal health beliefs about control can undermine adherence to medical and environmental remediation advice and likely contributes to high rates of uncontrolled asthma (George M., et al., 2015). They found that there was more endorsement for the use of ICS among controlled participants compared 
with those with uncontrolled asthma. Compared with participants with controlled asthma, more adults with uncontrolled asthma reported being non-adherent to ICS, expressed doubts about the ability to control asthma, rejected medical advice, and described more negative experiences with primary care providers. Further, most did not attempt to remediate environmental triggers that were within their control, preferring unconventional strategies to evidence-based recommendations. Moreover, beliefs that ICS treatments are over-prescribed and unnecessary for asthma control and cause systemic side effects have been identified as contributing to low ICS adherence in these groups and likely contribute as well to poor asthma control (Bender B. G., Bender S. E., 2005; George M., et al., 2015; Ponieman D., et al., 2009; Apter A. J., et al., 2003; Le T. T., et al., 2008; George M., et al., 2006; George M., 2003).

Finally, some studies have provided evidence that poor inhaler technique is a common problem among patients with asthma, and asthma control worsens as the number of mistakes in technique increases (Wells K., et al., 2008). Thus, this underlines the importance that each patient must be able to use their device correctly to obtain optimal benefit. If possible, device types should not be mixed for any individual patient.

\subsection{Measuring adherence to treatment}

Medical adherence is a crucial part of patient care and indispensable for reaching clinical goals (Yin Lam W., Fresco P., 2015). The WHO stated in 2003 that increasing the effectiveness of adherence interventions may have a far greater impact on the health of the population than any improvement in specific medical treatment (Sabate E, 2003). In contrast to adherence, nonadherence leads to poor clinical outcomes such as an increase in morbidity and death rates, and unnecessary health-care expenditures (Brown M. T., Bussell J. K., 2011; Johnson M. J., Williams M., Marshall E. S., 1999). The WHO defines adherence as "the extent to which the persons' behavior corresponds with agreed recommendations from a healthcare provider (Sabate E, 2003). This includes the initiation of the treatment, implementation of the prescribed regime, and discontinuation of the pharmacotherapy (Vrijens B, et al., 2012). Meanwhile, some studies classify adherence as either primary or secondary. Primary nonadherence is the frequency with which patients fail to fill prescriptions when new medications are started so it is related to refilling and initiation of the medication therapy (Fischer M. A., et al., 2010). Secondary nonadherence is defined as the medication being not taken as prescribed when prescriptions are filled. It does not only affect the clinical outcome but also affect the financial outcome of the health system (Solomon M. D., Majumdar S. R., 2010). Thus, measuring adherence is important to both clinicians and researchers. A poor estimation of medication adherence can lead to several problems which may be costly and 
dangerous in both settings. Effective treatments may be judged as ineffective, expensive diagnostic procedures may be ordered, and therapy may be unnecessary and dangerously intensified (Yin Lam W., Fresco P., 2015). In addition, results of clinical trials cannot be well interpreted and extrapolated without information on medical adherence, especially when treatment efficacy and dose-response relationships are miscalculated in studies where patients present poor adherence (Farmer K. C., 1999). Moreover, accurate estimates of medication adherence will provide better evidence on the consequences, predictors/risk factors, and strategies to improve medication adherence (Yin Lam W., Fresco P., 2015). Nevertheless, measurement of medication adherence can be quite challenging since and parameters of acceptable adherence need to be carefully delineated and appropriated for individual situations (Vitolins M. Z., et al., 2000).

Currently, many tools exist for measurements of medical adherence. However, these need to prove to be valid, reliable, and sensitive to change (Yin Lam W., Fresco P., 2015; Vitolins M. Z., et al., 2000). The selection of a method to monitor adherence should be based on individual attributes and goals/resources of the study or the clinical setting. Currently none of the available methods can be considered as a gold standard and the combination of methods is recommended (Farmer K. C., 1999). The most recent literature categorizes measurement of adherence into direct and indirect measures (Farmer K. C., 1999; Ho P. M., Bryson C. L., Rumsfeld J. S., 2009; Jimmy B., Jose J., 2011).

\subsubsection{Direct measures of adherence}

Direct measures include measurement of the drug or its metabolite concentration in body fluids, such as blood or urine and evaluation of the presence of a biological marker given with the drug and direct observation of patient's medication-taking behavior (Yin Lam W., Fresco P., 2015). These measures can be made randomly or at specific intervals (Farmer K. C., 1999). Even though direct measures are considered to be the most accurate and can be used as a physical evidence to prove that the patient has taken the medication, there are many drawbacks regarding their use (Yin Lam W., Fresco P., 2015). They simply generate a dichotomous result (yes vs. no) without revealing any pattern of the nonadherence or their causes (Farmer K. C., 1999). These tests themselves can also be very intrusive which may cause pressure and anxiety in patients (Yin Lam W., Fresco P., 2015). Furthermore, direct measures are very expensive and difficult to perform as many technicians and professionals are required to monitor the process and carry out the tests. Using direct observation as an example, patients can hide their medicines under tongue and discard them afterwards, making routine inspection impractical 
(Yin Lam W., Fresco P., 2015). Therefore, these measures are mostly used for patients under single-dose therapy or intermittent administration and hospitalized (Vermeire E., et al., 2001).

Other common direct adherence measuring methods include reviewing prescription refill records, measures involving electronic medication packaging devices or pill counts.

\subsubsection{Indirect measures of adherence}

Probably the most widely used tools of indirect medical adherence are questionnaires and scales. These questionnaires and scales were initially designed to minimize the limitations of other self-report methods by standardizing the measurement of adherence to a specific medication regime (Farmer K. C., 1999). These tools were then usually subjectively and objectively validated against other measures to accommodate various conditions, such as for a broad-ranged or single diseased population, or in different languages (Yin Lam W., Fresco P., 2015). Self-report questionnaires should be completed by patients themselves or their caretakers. However, questionnaires can be difficult for patients with low literacy levels (Tan X., Patel I., Chang J., 2014). In a recent systematic review by Nguyen et al 43 validated selfreport adherence scales were identified (Nguyen T. M., Caze A. L., Cottrell N., 2014). The majority of them (40 out of 43) had weighed the extent of implementation of a dosing regime, including the initiation, implementation, and discontinuation phases. Furthermore, the authors categorized the scales into 5 main groups that evaluate the following: (i) only medication-taking behaviors; (ii) both medication taking behavior and barriers to adherence; (iii) only barriers to adherence; (iv) only beliefs associated with medication adherence; and (v) both barriers to and beliefs associated with adherence (Yin Lam W., Fresco P., 2015; Nguyen T. M., Caze A. L., Cottrell N., 2014). This review defined medication-taking behaviors as any missing dose taken, as well as frequency on prescription refill while barriers to adherence were defined as tendency to forget, disease-specific reasons, regime complexity, and/or side effect of prescribed medications (Yin Lam W., Fresco P., 2015). Beliefs associated with adherence are related to personal concerns on the medication safety or the need of following the prescribed regime. Most analyzed scales have a recommended cutoff value (Nguyen T. M., Caze A. L., Cottrell N., 2014). Patients that took $80 \%$ or more of their medicines, as ascertained by an objective measure were reported as adherent, and those who took less than this cutoff value are reported as non-adherent, whilst some may correspond to other self-report measures that had been accredited by objective measures in advance (Yin Lam W., Fresco P., 2015; Nguyen T. M., Caze A. L., Cottrell N., 2014). Apart from correlation with other measures, the comparison of the adherence scale's mean scores of adherent and non-adherent populations can 
determine the cutoff value. On the other hand, some scales, like the Medication Adherence Questionnaire (MAQ), the 8-item Morisky Medication Adherence Scale (MMAS) and the Brief Medication Questionnaire, rank the degree of adherence instead of defining an absolute cutoff for adherence (Nguyen T. M., Caze A. L., Cottrell N., 2014).

The most useful adherence questionnaires and scales that include the concept of medication-taking behaviors, barriers to adherence and belief associated with adherence are the Brief Medication Questionnaire, the Hill-Bone Compliance Scale, the Eight-Item Morisky Medication Adherence Scale, the Medication Adherence Questionnaire, the Self-Efficacy for Appropriate Medication Use Scale and the Medication Adherence Report Scale.

\section{The Brief Medication Questionnaire}

The Brief Medication Questionnaire includes information on both patient's medicationtaking behavior and barriers to adherence (Lavsa S. M., Holzworth A, Ansani N. T., 2011; Svarstad B. L., Chewning B. A, Sleath B. L., Claesson C., 1999). It combines three different dimensions: a 5-item medication regime dimension, a 2-item belief dimension, and a 2-item recall dimension. These three dimensions assess how patients took each of their medications in the past week, on drug efficacy and bothersome features and remembering difficulties, respectively. Svarstad et al further reviewed that, with its ability to allow self-administration, evaluate multidrug regimens, and reduce practitioner's training, this questionnaire is popular among healthcare professionals (Svarstad B. L., Chewning B. A, Sleath B. L., Claesson C., 1999). It has been first suggested for diabetes and depression management and, ideally, patient's prescribed regime should be reviewed before being administered. Thus, the entire process may be more time-consuming comparatively to other questionnaires, which makes it difficult to be scored at the point of care (Lavsa S. M., Holzworth A, Ansani N. T., 2011).

\section{Hill-Bone Compliance Scale (Hill-Bone)}

As a measure of reviewing patient's medication-taking behavior and barriers to adherence, Hill-Bone has a limited generalizability since it targets patients with antihypertensive medication only. The test consists of 3 subscales, medication-taking behavior, ability to keep appointment, and sodium intake, and is rated on a four-point Likert-type scale. The number of items available for testing varies among population types. n14-item and 9-item tests have been validated for urban black and community-dwelling populations, respectively (Lavsa S. M., Holzworth A, Ansani N. T., 2011). When first designed, it has showed high internal consistency (Kim M. T., Hill M. N., Bone L. R., Levine D. M., 2000). And so it did when used in a primary healthcare setting from a study in South Africa (Lambert E. V., et al., 
2006). The authors also described that Hill-Bone has a higher performance for black than nonblack populations despite its high cultural sensitivity (Krousel-Wood M., et al., 2013). Meanwhile, the study with community-dwelling population also proved its high internal consistency in outpatient settings (Krousel-Wood M., et al., 2005). Thus, this scale has been suggested as suitable for use in studies specific for hypertension in a predominantly black population.

\section{Eight-Item Morisky Medication Adherence Scale (MMAS-8)}

Based on the MAQ, Morisky et al developed this 8-item MMAS (MMAS-8) in 2008 (Morisky D. E., et al., 2008). The first seven items are yes/no responses while the last item is a 5-point Likert response. The additional items focus on medication taking behaviors, especially related to underuse, such as forgetfulness, so barriers to adherence can be identified more clearly (Tan X., Patel I., Chang J., 2014). The MMAS measures medication compliance on a scale of $0-11$, with lower scores indicating greater adherence. The total MMAS score is obtained by summing ratings for all scale items. Seven items are answered by either yes (score $=1)$ or no $($ score $=0)$ responses, and one item assesses using 5 point Likert-type responses ranging from "usually" to "all the time" (usually =0; all the time =4). The MMAS has been used across many chronic diseases, including asthma, as a self-reported measure of adherence to medications and has demonstrated good reliability and predictive validity (Morisky D. E., Ang A., Krousel-Wood M., Ward H. J., 2008; Krousel-Wood M., Thomas S., Muntner P., Morisky D., 2004). 93\% sensitivity and 53\% specificity were reported while validating in "very low income minority patients treated for hypertension seeking routine care in a clinic setting" (Morisky D. E., Ang A., Krousel-Wood M., Ward H. J., 2008). MMAS was also validated with outstanding validity and reliability in patients with other chronic diseases (Tan X., Patel I., Chang J., 2014). As a result, it is probably the most accepted self-report measure for adherence to medication. Along with blood pressure control data, MMAS should be able to identify medication nonadherence and help control blood pressure (Morisky D. E., Ang A., KrouselWood M., Ward H. J., 2008). Therefore, it is recommended to serve as a screening tool for validated conditions in the clinic setting.

\section{Medication Adherence Questionnaire (MAQ)}

The MAQ is also known as the 4-item Morisky Medication Adherence Scale (MMAS-4) and Morisky Scale (Yin Lam W., Fresco P., 2015; Tan X., Patel I., Chang J., 2014; Nguyen T. M., Caze A. L., Cottrell N., 2014; Lavsa S. M., Holzworth A, Ansani N. T., 2011; Culig J., Leppee M., 2014). This BioMed Research International 7 questionnaire is the quickest to administer and score and is only able to identify barriers to adherence due to its length 
(Lavsa S. M., Holzworth A, Ansani N. T., 2011). The closed question format with "yes-saying" bias allows disclosures of nonadherence (Tan X., Patel I., Chang J., 2014). Since it has been validated in the broadest range of diseases and in patients with low literacy, it is the most widely used scale for research (Culig J., Leppee M., 2014). In a study on factor structure and validity of MAQ for cigarette smokers, it was reported that the coefficient alpha reliability of MAQ varied among studies as well as validity estimates (Toll B. A., et al., 2007). Compared to MMAS-8, MAQ has poorer psychometric properties. In the first validation for hypertensive population, the sensitivity and specificity were $81 \%$ and $44 \%$, respectively (Morisky D., Green L. W., Levine D. M., 1986). As a result, MMAS-8 has become more popular than MAQ.

\section{The Self-Efficacy for Appropriate Medication Use Scale (SEAMS)}

The SEAMS is a 13-item, 3-point Likert-type scale focusing on self-efficacy in chronic disease management while measuring barriers to medication adherence. It may be difficult to carry out at the point of care because of its length. However, this scale has been validated in various chronic conditions (Yin Lam W., Fresco P., 2015; Lavsa S. M., Holzworth A., N. T., 2011; Culig J., Leppee M., 2014). Reliability of this scale was measured by its internal consistency. With coefficient alpha reliability at 0.89 and 0.88 , on low and high literacy populations, respectively, SEAMS is considered to be an excellent self-report tool for measuring medication adherence in chronic diseases management (Yin Lam W., Fresco P., 2015; Lavsa S. M., Holzworth A, Ansani N. T., 2011).

\section{Medication Adherence Report Scale (MARS)}

MARS assesses both beliefs and barriers to medication adherence (Thompson K., Kulkarni J., Sergejew A. A., 2000; Culig J., Leppee M., 2014). It is based on the Drug Attitude Inventory (DAI), a common psychiatric adherence survey. By incorporating the questions from MAQ, it aims to reduce the deficiencies of DAI. As a result, it is able to examine medication taking behaviors and attitudes toward medication with higher validity and reliability values. The long version of the MARS is a validated 10-item questionnaire that has shown to have good internal, construct, and criterion validity, including correlations with objective measures of adherence (electronic monitoring and pharmacy dispensing data) (Cohen J. L., et al., 2009; Van Steenis M., et al., 2014). The MARS contains items that measure intentional ("I avoid using it if I can") and unintentional ("I forget to use it") non-adherence and these questions are phrased such that nonadherence is considered common to minimize social desirability bias. Medication use is rated on a 5-point Likert scale (Krapek K., et al., 2014; Cochrane G. M., Horne R., Chanez P., 1999). The short version of the MARS is a five-item self-report scale for assessment 
of adherent behavior that includes assessment of unintentional non-adherent behavior ("I forgot to take them", item 1) and intentional non-adherent behavior ("I alter the dose", item 2. "I stop taking them for a while", item 3. "I decide to miss out a dose", item 4. "I take less than instructed", item 5). Each item is answered using a five-graded response scale, ranging from very often (1) to never (5). Low scores indicate low levels of adherent behavior (Schatz M., et al., 2005). The internal consistency reliability of MARS is unclear (Lavsa S. M., Holzworth A, Ansani N. T., 2011). Still, Thompson et al. showed that this scale has strong positive correlations compared to MAQ. It was designed and first validated for patients with schizophrenia (Thompson K., Kulkarni J., Sergejew A. A., 2000). Hence, this scale is limited to use in patients with chronic mental illness.

\subsection{Factors related to medical adherence in asthma patients}

\subsubsection{Definition, characteristics and prevalence of treatment adherence in asthma patients}

Prescribed treatments are effective only if taken. Patient nonadherence to treatment is an important problem across chronic illnesses, with as much as $30-50 \%$ of prescribed medications not taken as directed (Barber N., et al., 2004). This level of nonadherence represents a loss to health-care systems, because of wasted resources and costs of inadequate treatment, and to patients, because of the missed opportunity for improving health (Horne R., 2006). The combined effects of failure to comply with recommendations and poor patient adherence to treatment, along with low usage of preventive medicine and low expectations of treatment, can be considered as the leading causes of poor disease control (Fueyo A., 2007).

The problem of non-adherence to the medical therapy is one of the main reasons of insufficient asthma control (Krishnan J. A., et al., 2004; Rabe K. F., et al., 2000; Rabe K. F., et al., 2004). As a consequence of poor adherence, a general failure to achieve the set guideline goals arises (NAEPP (National Asthma Education and Prevention Program), 2017; Nicklas R. A., 1997; Legorreta A. P., et al., 1998). Non-adherence to controller therapy, especially ICS, is common and an important factor in poor asthma control (Spector S., 2000; Suissa S., et al., 2000). However, non-adherence is often a hidden problem because it is not commonly assessed at routine asthma visits. Patients may be reluctant to admit non-adherence to avoid disappointing their physician, and physicians may be reluctant to query about adherence because they lack a clear and easy method to improve it. Formal interventions to improve adherence have not been successful, perhaps because of lack of complete understanding about the causes of non-adherence (Haynes R. B., et al., 2002). 
Nonadherence is reported to range between $20 \%$ and $40 \%$ in acute illness, $30-60 \%$ in chronic diseases, and reaches $50-80 \%$ for preventive treatments (Christensen A. J., 2004). The 2003 WHO report on medication adherence mentioned that increasing the effectiveness of adherence interventions may have a far greater impact on the health of the population than any improvement in specific medical treatments (Sabate E, 2003). Thus, a high percentage of asthmatic patients incorrectly follows their doctor's prescriptions, resulting in incorrect medication intake. Studies assessing treatment plans in asthma patients have revealed that adherence to medication range between 30 to 60\% (Cerveri I., et al., 1999; Bender B. G., Bender S. E., 2005; Bender B. G., et al., 2007). The data on compliance, collected in the framework of the European Community Respiratory Health Survey (ECRHS) on 1771 asthma patients 20-44 years-of-age identified in 14 countries, assessed the extent of noncompliance and its variation across countries (Cerveri I., et al., 1999). The median percentage of current asthmatics who had received a medical prescription at least once was $95 \%$. The compliance of those patients who had received a medical prescription was found to be $67 \%$ in all countries but with large variations ranging from $40 \%$ (USA) to $78 \%$ (Iceland). During exacerbations patients' rate of compliance increased to $72 \%$. Poor adherence to asthma medication was found to be between 30-40\% in France, Germany and Italy (Rabe K. F., et al., 2000; Cerveri I., et al., 1999; Bender B. G., Bender S. E., 2005).

Thus, there is considerable room for improvement in adherence to asthma medication treatment in most primary health-care systems. Because poor adherence may reduce the likelihood of achieving and maintaining good asthma control, it is important that adherence to prescribed asthma medication be addressed by the health-care provider during regular followup consultations (Global Initiative for Asthma. Global Strategy for Asthma Management and Prevention, 2017). Adherence may be regarded as a multifaceted behavior that is influenced by a variety of factors, one of which is the health-care provider (Sabate E, 2003). Asthma clinics led by specially trained asthma nurses have been shown to be effective in asthma management, for instance, in relation to adherence (Lindberg M., Ekstrom T.,Moller M., Ahlner J., 2001). Moreover, the interaction between the health-care professional and the patient regarding joint treatment decisions, taken by the asthma patient and the clinician together, seems to have a positive effect on adherence as well (Wilson S. R., et al., 2010). Another factor affecting adherence is beliefs about the asthma medication (Axelsson M., Ekerljung L., Lundbäck B., 2015; Menckeberg T. T., et al., 2008; Ponieman D., et al., 2009; Horne R., Weinman, J., 1999). Individuals with asthma who, for instance, believe that their medication is necessary for their present and future health or that it prevents exacerbation of their disease are more likely to be adherent. In contrast, individuals who are concerned about their asthma medication are more 
inclined to deviate from the prescribed treatment (Menckeberg T. T., et al., 2008; Ponieman D., et al., 2009; Horne R., Weinman, J., 1999). It has also been reported that patients with uncontrolled asthma tend to be skeptical about their asthma medication, which may cause them to choose symptom management strategies other than the medication (George M., et al., 2015).

Causes of non-adherence can be divided into two categories: unintentional and intentional nonadherence (Horne R., 2006; Cochrane G. M., Horne R., Chanez P., 1999; Horne R., Clatworthy J., Hankins M., 2010). Both are important factors in clarifying non-adherent behavior. Unintentional non-adherence results from practical barriers to treatment, such as language barriers, forgetfulness, and inadequate understanding of the instructions. Poor inhaler technique is a good example of unintentional non-adherence. Intentional non-adherence, on the other hand, derives from patient choice to take less medication or different than prescribed. Concordance refers to the degree to which the patient and health-care provider agree about the nature of the patient's illness and chosen treatment path (Horne R., 2006; Marinker M., Shaw J., 2003). As such, concordance recognizes that patients and health-care providers bring to the consultation two sets of (potentially opposing) beliefs about the illness and treatment. Concordance also incorporates a presumption of adequate communication between patient and health-care provider. When beliefs differ, and the patient and provider fail to reach an understanding during the consultation, no concordance is the result, and patient non-adherence to treatment is more likely. Vrijens et al, furthermore, proposed Ascertaining Barriers to Compliance $(\mathrm{ABC})$ taxonomy conceptualizes adherence to medications in line with principles of behavioral and pharmacological science (Vrijens B, et al., 2012). The ABC taxonomy defines the overarching concept of "medication adherence" as the process by which patients take their medication as prescribed and subdivides it into three essential elements: (A) initiation; (B) implementation, and (C) persistence. This subdivision outlines the sequence of events that have to occur for a patient to experience the optimal benefit from his or her prescribed treatment regimen (Vrijens B, et al., 2012).

\subsubsection{Patients' beliefs about medications and adherence: the necessity-concerns framework}

The self-regulatory model was developed in order to explain illness-related behavior, including adherence to treatment recommendations within the field of non-communicable diseases (Williams L. K., et al., 2004). The necessity-concern framework of the self-regulation theory proposed may affect asthma control as an individual's understanding of his or her disease and its treatment may be an important mediator of key health behaviors, such as medication use (Leventhal H., 2004). Patients' personal beliefs about treatment, particularly the way in which 
they judge their personal need for treatment relative to their concerns about potential adverse effects, with low adherence associated with doubts about necessity and with concerns (Horne R., Weinman J., 2002; Leventhal H., 2004; O’Brien M. K., Petrie K., Raeburn J., 1992; Wright M. T., 2000). The framework seems to explain non-adherence across many chronic illnesses. Both factors are relevant in most situations, and there may be an interplay between them: for example, in a situation of low necessity, concerns may become more salient. Types of concerns and, more commonly, levels of concerns vary from individual to individual, and there may also be cultural differences (Horne R., et al., 2004).

In asthma, patients often doubt the necessity of taking a daily medication for a condition that they experience episodically. In the worldwide AIRE survey, people commonly underestimated the seriousness of their symptoms (and overestimated control of their asthma) (Rabe K. F., et al., 2000; Neffen H., 2005). Moreover, patients often have concerns about potential side effects from taking ICS. In a recent study, patients' beliefs about ICS were shown to correlate with their adherence, as measured both by self-report as well as by pharmacy prescribing records (Menckeberg T. T., et al., 2008). Other studies have also revealed that beliefs in the necessity of medications were associated with better medical adherence (Axelsson M., Ekerljung L., Lundbäck B., 2015; Menckeberg T. T., et al., 2008; Van Steenis M., et al., 2014; Koster E. S., et al., 2015). For instance, data in 93 Dutch asthma patients showed that higher necessities were associated with higher self-reported adherence, suggesting that it could be more important to focus on necessities than on concerns in an attempt to improve adherence (Van Steenis M., et al., 2014). Another Dutch study in 240 asthma patients furthermore revealed that both self-reported adherence and adherence by pharmacy records correlated with ICS necessity beliefs and concerns (Menckeberg T. T., et al., 2008). Finally, regular asthma follow-up consultations were associated with both higher adherence and the belief that asthma medication was necessary in 165 Swedish patients (Axelsson M., Ekerljung L., Lundbäck B., 2015). Moreover, concerns about the use of asthma medication was found to be an important factor associated with lower treatment adherence (Horne R., Weinman J., 2002; Menckeberg T. T., et al., 2008; Ponieman D., et al., 2009; Cooper V., et al, 2015). 


\subsubsection{Patients' illness perception and adherence}

The Common-Sense Model of Self-Regulation (CSM), also known as Illness perception model, was developed by Leventhal and co-workers (Leventhal H., Phillips L. A., Burns E., 2016). It is a theoretical model that is widely used in assessing how patients' illness perception and medical adherence are related (Leventhal H., Phillips L. A., Burns E., 2016; Cameron L. D., Leventhal H., 2003). The model looks for explaining the association between illness perception, coping strategies, underlying health and illness behavior. The general concept of the CSM is that patients are active problem solvers. Thus, the first step in CSM is the time point when patients are faced with symptoms of their illness. Once the patient senses the symptoms a process is initiated to solve the health problem by creating plans to cope with it (Leventhal H., Phillips L. A., Burns E., 2016; Leventhal H., Brisette I., Leventhal E., 2003). The second step aims at reducing both health threat and emotional reactions associated with that threat. The CSM proposes that the coping plans and subsequent reactions to health threats depend on personal history, cultural and social factors. The third step of the CSM is the person's evaluation of the effectiveness of the coping strategy.

Only a very few study have assessed the association between illness perception and treatment adherence in asthma patients (Olszanecka-Glinianowicz M., Almgren-Rachtan A., 2014; Unni E., Shiyanbola O. O., 2016; Horne R., Weinman J., 2002; Leventhal H., et al., 2004; Byer B., Myers L. B., 2000). In a cross-sectional study of 100 British community-based patients showed that non-adherent behaviors were associated with doubts about the necessity of medication and concerns about its potential adverse effects and with more negative perceived consequences of illness (Horne R., Weinman J., 2002). Furthermore, a large Polish survey in 3,618 asthma patients, illness perception, younger age, disease duration and severity were predictors of adherence to treatment with fluticasone propionate and formoterol fumarate among patients with asthma (Olszanecka-Glinianowicz M., Almgren-Rachtan A., 2014). Byers and colleagues indicated that number of preventer inhaler prescriptions was significantly associated with patient belief $\mathrm{s}$ about the necessity of their asthma medication, and external cause; number of reliever inhaler prescriptions was significantly associated with belief in a long illness duration and high morbidity (Byer B., Myers L. B., 2000). Finally, it has been reported that interventions focusing on illness perception helped to support chronic obstructive pulmonary disease patients in their disease management and to improve health-related quality of life (Unni E., Shiyanbola O. O., 2016; Weldam S. W., et al., 2014). 


\section{MATERIAL AND METHODS}

\subsection{Study population}

\subsubsection{Design and study participants}

The study population of this cross-sectional patient survey consisted of asthma patients attending outpatient pulmonologist consultations in Riga, Latvia during September 2013 to December 2015. Latvian asthma patients receive their initial disease diagnosis and treatment initiation in a pulmonologist practice. Initial diagnosis must be verified by a spirography that is performed by a pulmonologist or allergologist. They get there in larger part by a referral by a general practitioner (GP) or by direct patient contact. The role of GPs within the Latvian health care system is mainly to ensure that a patient follows the treatment regime set forth by the specialist. Only patients referred by a GP to a NHS registered practice can get their medication reimbursed by NHS. In a first step, a list of all pulmonologists from the database of the National Health Service (NHS) of the medical doctors that have contractual rights to prescribe reimbursed medicines was acquired. Then, pulmonologists in large medical centers and hospitals in Riga and in bigger towns of Latvia were invited to join the study and 15 of these practices agreed to participate (convenience sample). These 15 medical centers employ 66 pulmonologists that is $51 \%$ of all 129 pulmonologists in Latvia that have a contract with NHS. We assumed these 15 practices to be representative of all pulmonologist practices in Latvia. Each pulmonologist was advised to invite their patients to join the survey. Inclusion criteria: patients that have been using asthma controller medication - inhaled corticosteroids (ICS) in monotherapy or in combination for at least 12 months. Exclusion criteria: patients that have been prescribed episodic ICS therapy and patients younger than 15 years of age.

\subsubsection{Sample size calculations}

The sample size was calculated to detect a prevalence of poor asthma control of $50 \%$ with a margin of error of $5 \%$, and a power of $95 \%$. As no information was available about the prevalence of poor asthma control in Latvia, we set poor asthma control to $50 \%$ to guarantee a big enough sample size to test our study question as a prevalence close to $50 \%$ require by definition a bigger sample size. The total sample size needed and respectively studied was 352 people and data on 352 subjects were analyzed. According to interviewers feedback this number represents approximately $75 \%$ of all patients that were invited to be included into the study. 


\subsection{Assessment of main variables}

A self-administered questionnaire was used to assess socio-demographic and economic factors such as age, education, income and sex. For education, there were four groups - basic education, secondary education, vocational education and higher education (includes bachelor, master and doctoral degrees). For net personal income, there were four groups - less than 300 EUR per month, between 300 and 550 EUR per month, between 550 and 750 EUR per month and more than 750 EUR per month. The majority $(33,8 \%)$ of the patients had higher education and were earning at least 300 euros per month. Two out of three patients $(63,3 \%)$ were using corticosteroids in monotherapy and one third $(33,3 \%)$ a combination therapy consisting of corticosteroids and a beta 2 mimetic drug. Age, income and education were statistically significantly differently distributed between men and women.

Table 3.1

Baseline characteristics of the study sample

\begin{tabular}{lcccc}
\hline & $\begin{array}{c}\text { Men } \\
(\mathbf{n = 8 5})\end{array}$ & $\begin{array}{c}\text { Women } \\
(\mathbf{n = 2 6 4 )}\end{array}$ & $\begin{array}{c}\text { Total } \\
(\mathbf{n = 3 5 2})\end{array}$ & p-value \\
\hline Age, mean (SD) & $53.7(17.4)$ & $58.7(16.6)$ & $57.5(16.9)$ & 0.017 \\
Education, \% & & & & 0.006 \\
Basic & 3.5 & 7.5 & 6.5 & \\
Secondary & 23.3 & 27.1 & 26.1 & \\
Vocational & 47.7 & 28.9 & 33.5 & \\
Higher & 25.6 & 36.5 & 33.8 & \\
Income, \% & & & & 0.005 \\
$<300$ (month & 16.7 & 25.3 & 23.2 & \\
300-550 €/month & 36.9 & 48.2 & 45.5 & \\
550-750 €/month & 28.6 & 18.3 & 20.8 & \\
$>750 € /$ month & 17.9 & 8.2 & 10.6 & \\
Asthma medication, \% & & & & \\
Corticosteroids & 62.8 & 63.4 & 63.3 & 1.00 \\
Corticosteriods+beta 2 mimetic & 33.7 & 33.2 & 33.3 & 1.00
\end{tabular}

\subsubsection{Asthma control}

Level of asthma control was assessed using the Asthma Control Test (ACT), a validated five-item scale that reliably assesses asthma control over a recall period of four weeks. The ACT consists of the following questions: "How much of the time did your asthma keep you from getting as much done at work, school or at home?". "How often have you had shortness 
of breath?". "How often did your asthma symptoms wake you up at night or earlier than usual in the morning?", "How often have you used your rescue inhaler or nebulizer medication?" and "How would you rate your asthma control?". Each item was scaled from 1 to 5, and by summing the response values a scale score was calculated ranging from poor (5) to total (25) control (Nathan R. A., et al., 2004; Schatz M., et al., 2006). A cut-off point of $\leq 19$ was defined to indicate poorly controlled asthma, and scores of 20 points or more corresponded to wellcontrolled asthma. Weight of all questions in ACT questionnaire is regarded as equal. ACT scores have shown to be well correlated with baseline per cent predicted forced expiratory volume (Schatz M., et al., 2006). Responsiveness of the ACT to changes in asthma control and lung function was demonstrated with significant correlations between changes in ACT scores and changes in percent predicted FEV1 values $(r=0.29, \mathrm{P}<.001)$. An ACT score of 19 or less provided optimum balance of sensitivity $(71 \%)$ and specificity $(71 \%)$ for detecting uncontrolled asthma (Schatz M., et al., 2006).

\subsubsection{Assessment of adherence}

Adherence to asthma medication was assessed using the Morisky Medication Adherence Scale (MMAS) and two different versions of the Medication Adherence Reporting Scale (MARS). The MMAS is a self-report tool, it was used to assess asthma medication adherence (Morisky D., Green L. W., Levine D. M., 1986). The MMAS is an eight-item questionnaire that measures medication compliance on a scale of $0-11$, with lower scores indicating better adherence. The total MMAS score was obtained by summing ratings for all scale items. Seven items were answered by either yes $($ score $=1)$ or no $($ score $=0)$ responses, and one item was assessed using 5 point Likert-type responses ranging from "usually" to "all the time" (usually =0; all the time =4). The MMAS has been used across many chronic diseases, including asthma, as a self-reported measure of adherence to medications and has demonstrated to be reliable and a valid tool for estimating compliance (Thompson K., Kulkarni J., Sergejew A. A., 2000; Krousel-Wood M., Thomas S., Muntner P., Morisky D., 2004). The long version of the MARS is a validated 10-item questionnaire that has shown to have good internal, construct, and criterion validity, including correlations with objective measures of adherence (electronic monitoring and pharmacy dispensing data) (Cerveri I., et al., 1999; Sutherland E. R., Martin R. J., 2005). The MARS contains items that measure intentional ("I avoid using it if I can") and unintentional ("I forget to use it") nonadherence and these questions are phrased such that nonadherence is considered common to minimize social desirability bias. Medication use is rated on a 5-point Likert scale. The short version of the 
MARS is a five-item self-report scale for assessment of adherent behavior that includes assessment of unintentional non-adherent behavior ("I forgot to take them", item 1) and intentional non-adherent behavior ("I alter the dose", item 2. "I stop taking them for a while", item 3. "I decide to miss out a dose", item 4. "I take less than instructed", item 5). Each item was answered using a five-graded response scale, ranging from very often (1) to never (5). Low scores indicate low levels of adherent behavior (Wroe A. L., 2002). During analysis the 5-item and 10-item versions were analyzed separately to detect data consistency of results.

\subsubsection{Medication beliefs}

Medication beliefs were assessed using the five items of greatest relevance to asthma medication adapted from the Beliefs about Medication Questionnaire (BMQ), a validated tool across many disease conditions (Horne R., Weinman, J., 1999; Horne R., Weinman, J, Hankins M., 1999). The specific-necessity scale contains 5 items that assess patients' beliefs about specific necessity to take prescribed chronic medications. All three questions assessing patients' beliefs about specific necessity to take prescribed chronic medications or concerns were selected from the original BMQ. The answers of the BMQ were dichotomized into (i) "I agree/ I completely agree" and (ii) "Not sure/I disagree/I completely disagree". All belief items had Likert scale responses.

\subsubsection{Illness perception}

The Brief Illness Perception Questionnaire (brief IPQ) was used to obtain information on illness perception of the study participants. The Brief IPQ consists of nine items and a causal question (Weinman J., et al., 1996; Moss-Morris R., et al., 2002; Broadbent E., et al., 2006). All of the items except the causal question are rated using a 0 to 10 response scale. Five of the items assess cognitive illness representations: consequences (item 1), timeline (item 2), personal control (item 3), treatment control (item 4), and identity (item 5). Two of the items assess emotional representations: concern (item 6) and emotions (item 8). One item assesses illness comprehensibility (item 7). Assessment of the causal representation is by an open-ended response, which asks patients to list the three most important causal factors in their illness (item 9). IPQ was used as a continuous variable. For every unit increase in IPQ, the odds of the outcome event (i.e. Morisky, MARS) increased by the odds. For instance, for one unit increase in IPQ for "How much does your illness affect your life" the probability of poor asthma control increased by $47 \%$ (or 1.47 -fold). 


\subsection{Statistical analysis}

The Statistical Package for the Social Sciences (SPSS) IBM 21.0 was used to analyze the data. Means, standard deviations, and frequencies are presented to describe the characteristics of the study sample. For Asthma Control Test a cut-off point of $\leq 19$ was defined to indicate poorly controlled asthma, and scores of 20 points or more corresponded to wellcontrolled asthma (Nathan R. A., et al., 2004; Schatz M., et al., 2006). A cutoff point of $>6$ (MARS-5), >14 (MARS-10), >1 (MMAS) was used to define poor medical adherence. These cut-off points were chosen according to the ones proposed in previous studies (Morisky D. E., Ang A., Krousel-Wood M., Ward H. J., 2008; Krapek K., et al., 2004; Wroe A. L., 2002).

The answers of the BMQ were dichotomized into (i) "I agree/I completely agree" and (ii) "Not sure/I disagree/I completely disagree" similar to the methods of previous study to ease clinical application (Rabe K. F., et al., 2004; Byer B., Myers L. B., 2000). The logistic regression analyses were first conducted for each variable alone (univariate analysis). In the multivariate logistic analysis the outcome variable was controlled for age, income and educational level. The odds ratio (OR) and respective 95\% confidence interval are presented for all models. The OR presented in the tables are for the "I agree/I completely agree" categories with the "Not sure/I disagree/I completely disagree" category as reference group. The validity of each logistic regression model was assessed by the Hosmer-Lemeshow test.

\subsection{Ethical aspects}

Methods were performed in accordance with relevant guidelines and regulations. Methods and patient consent form were approved in writing by the P. Stradins Clinical University Hospital Development Society Ethics committee for clinical research (original name in Latvian: P. Stradiṇa Klīniskās universitātes slimnīcas Attīstības biedrības klīniskās izpētes etikas komiteja). A written consent was obtained from all participants involved in the study. 


\section{RESULTS}

\subsection{Sociodemographic and socio-economic factors associated with poor asthma control and poor treatment adherence}

The prevalence of poor asthma control was $63 \%$ in men and $66 \%$ in women. The prevalence of poor treatment adherence ranged between 58\% according to MARS 5-item scale to $76 \%$ according to MARS 10 -item scale in men and $69 \%$ in women (reference Table 4.1 ).

Table 4.1

Adherence and disease control characteristics of the study sample

\begin{tabular}{lcccc}
\hline & $\begin{array}{l}\text { Men }(\mathbf{n}=\mathbf{8 5}) \\
\text { \% (95\% CI })\end{array}$ & $\begin{array}{c}\text { Women }(\mathbf{n}=\mathbf{2 6 4}) \\
\mathbf{\%}(\mathbf{9 5 \%} \mathbf{C I})\end{array}$ & $\begin{array}{c}\text { Total }(\mathbf{n}=\mathbf{3 5 2}) \\
\mathbf{\%}(\mathbf{9 5 \%} \mathbf{C I})\end{array}$ & p-value \\
\hline $\begin{array}{l}\text { Poor asthma control, \% } \\
\begin{array}{l}\text { Poor treatment } \\
\text { adherence, \% }\end{array}\end{array}$ & $628(52.2-72.3)$ & $66(60.2-71.5)$ & $65.3(60.2-70.0)$ & 0.604 \\
$\begin{array}{l}\text { Morisky scale } \\
\text { MARS (5-item) scale }\end{array}$ & $72.1(61.8-80,5)$ & $69.4(63.6-74.6)$ & $70.1(65.1-74.6)$ & 0.686 \\
MARS (10-item) scale & $58.1(47.6-68.0)$ & $68.7(62.9-73.9)$ & $66.1(61.0-70.8)$ & 0.089 \\
\hline
\end{tabular}

None of the sociodemographic or socio-economic factors were statistically significant predictors of poor treatment adherence according to the Morisky or the MARS 10-item scale (Table 4.1). 


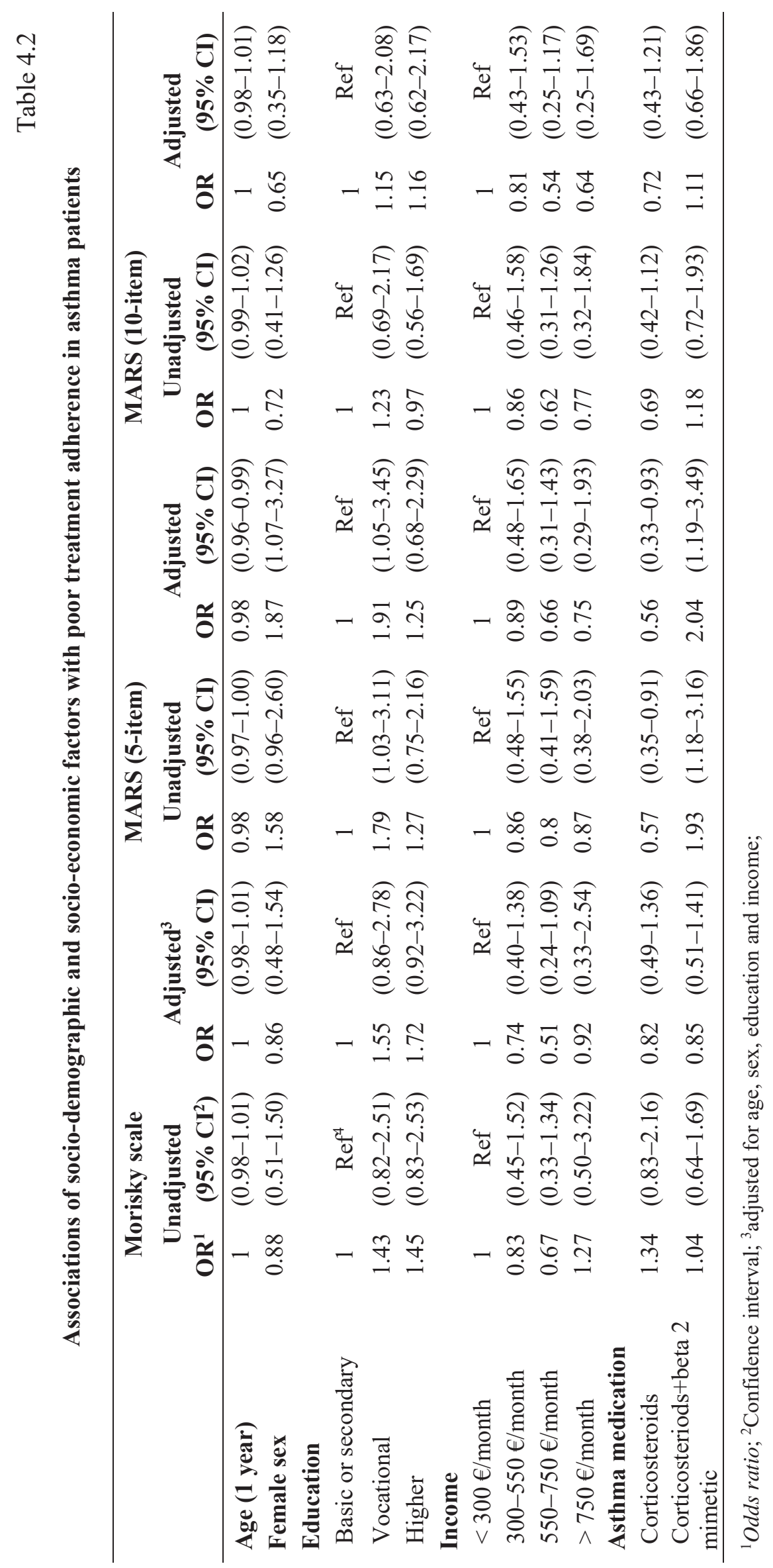


A higher level of education seemed to increase the odds to have poor treatment adherence, but the association was not statistically significant. However, when the MARS 5-item scale was used, increasing age (OR 0.98 (95\% confidence interval (CI) 0.97-1.00) and monotherapy with corticosteroids (OR 0.57 ; 95\% CI $0.35-0.91$ ) reduced the odds of poor treatment adherence. Moreover, professional education level (OR 1.79; 95\% CI 1.03-3.11) or the combined use of corticosteroids and beta 2 mimetics (OR 1.93; 95\% CI 1.18-3.16) increased the odds of poor treatment adherence.

\subsection{Associations of different asthma medication adherence scores with poor asthma control}

Table 4.3 shows the associations of the different asthma medication adherence scores with poor asthma control in the study sample. In the unadjusted model, the 5-item MARS was statistically significantly associated with poor asthma control (OR 0.39; 95\% CI 0.15-1.00). However, none of the three adherence scores was able to statistically predict poor disease control in Latvian asthma patients after adjustment for covariates.

Table 4.3

Associations of different asthma medication adherence ${ }^{1}$ scores with poor asthma control $^{2}$

\begin{tabular}{|c|c|c|c|c|}
\hline & \multicolumn{2}{|c|}{ Univariate } & \multicolumn{2}{|c|}{ Multivariate ${ }^{5}$} \\
\hline & $\mathbf{O R}^{3}$ & $\left(95 \% \mathrm{CI}^{4}\right)$ & OR & $(95 \% \mathrm{CI})$ \\
\hline \multicolumn{5}{|l|}{ Men } \\
\hline MARS (5-item) & 0.39 & $(0.15-1.00)$ & 0.36 & $(0.12-1.09)$ \\
\hline MARS (10-item) & 1.05 & $(0.38-2.90)$ & 1.41 & $(0.43-4.65)$ \\
\hline Morisky & 1.02 & $(0.38-2.69)$ & 1.48 & $(0.49-4.50)$ \\
\hline \multicolumn{5}{|l|}{ Women } \\
\hline MARS (5-item) & 1.04 & $(0.60-1.79)$ & 1.2 & $(0.67-2.17)$ \\
\hline MARS (10-item) & 1.68 & $(0.98-2.87)$ & 1.61 & $(0.91-2.86)$ \\
\hline Morisky & 1.09 & $(0.63-1.89)$ & 0.94 & $(0.52-1.70)$ \\
\hline \multicolumn{5}{|l|}{ All } \\
\hline MARS (5-item) & 0.81 & $(0.51-1.30)$ & 0.87 & $(0.52-1.44)$ \\
\hline MARS (10-item) & 1.5 & $(0.93-2.40)$ & 1.43 & $(0.87-2.36)$ \\
\hline Morisky & 1.07 & $(0.67-1.72)$ & 0.99 & $(0.60-1.66)$ \\
\hline
\end{tabular}




\subsection{Patients' beliefs about specific necessity and concerns about medicines associated with poor asthma control}

Table 4.4 shows the results of the logistic regression analysis of the different beliefs about medicines in regard of poor asthma control. Agreement on necessity of asthma medication was statistically significantly related to an increase in the odds of poor asthma control. The increase in risk of poor asthma control was almost three-fold in patients who were convinced that their life fully depends on their medication (OR 2.89; 95\% CI 1.78-4.71). In addition, beliefs such as "without asthma medication life would be impossible" (OR 2.69; 95\% CI 1.56-4.12) or "without asthma medication the patient would be very ill" (OR 2.69; 95\% CI 1.66-4.38) were significantly related to poor asthma control after adjustment for age, education and income. Finally, if the patient was concerned by the need to use his asthma medication constantly, the probability of poor asthma control doubled (OR 1.94; 95\% CI 1.19-3.17) compared to those without concerns. Neither were concerns regarding long-term use nor understanding of ones' asthma medication statistically significantly related with poor asthma control.

Table 4.4

Odds ratio of patients' beliefs about specific necessity and concerns about medicines in regard poor asthma control

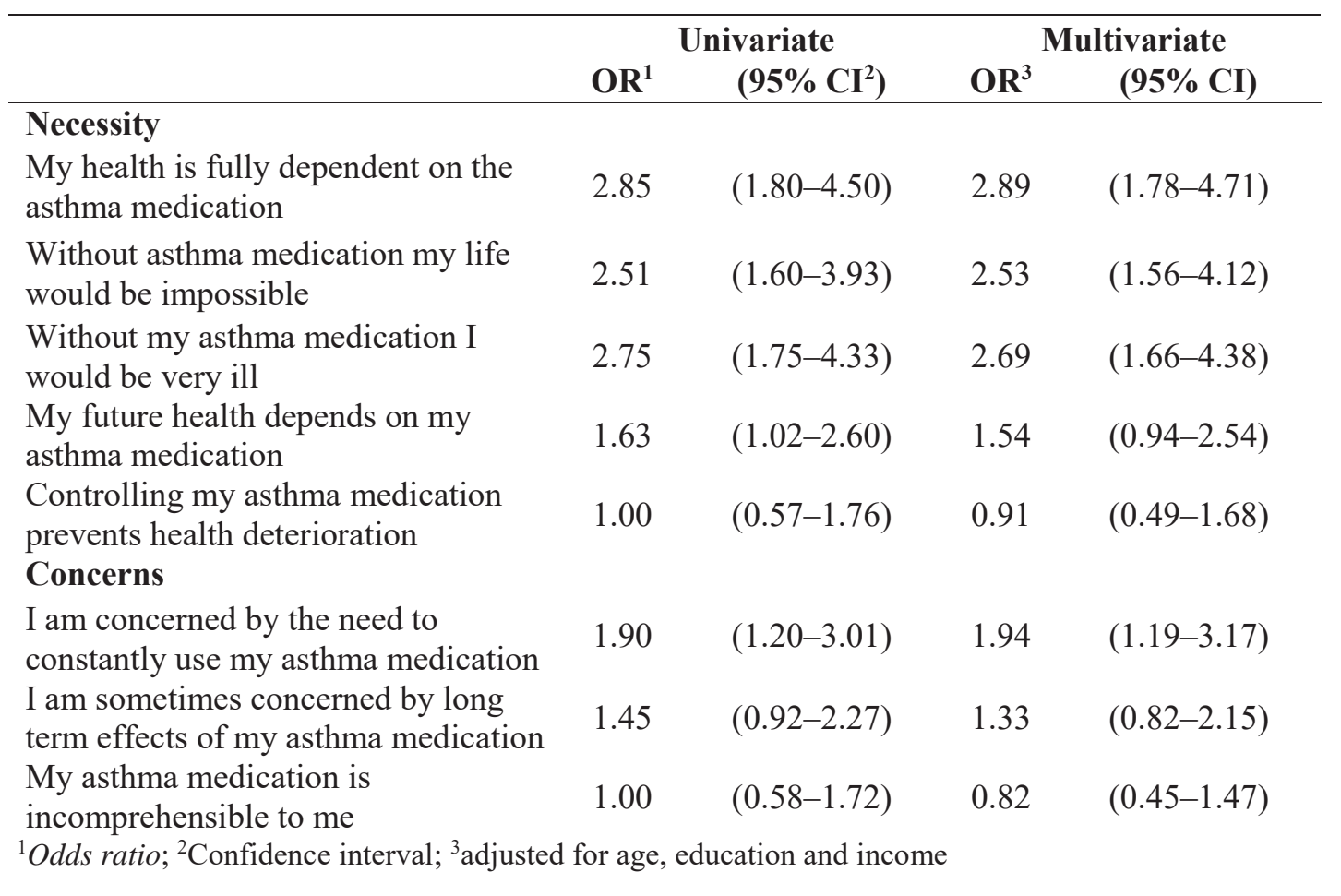




\subsection{The association between cognitive and emotional illness questionnaire and poor asthma control}

Several cognitive and emotional illness indicators predicted poor asthma control in the study patients regardless of controlling for other covariates (Table 4.5). The more the asthma patients perceived that their illness affect their life, the higher the probability of poor asthma control (OR 1.47; 95\% CI 1.31-1.65). On one hand, estimated duration, concern and emotional affection of asthma increased the odds of poor asthma control. On the other, a better self-perception of asthma control (OR $0.7 ; 95 \%$ CI $0.61-0.79$ ) or considering that the current treatment is helpful (OR $0.84 ; 95 \%$ CI 0.74-0.95) were related to improved asthma control. Understanding their illness did not affect asthma control in the study population.

Table 4.5

Odds ratio of each of the eight items of the cognitive and emotional illness questionnaire in regard probability of poor asthma control

\begin{tabular}{lcccc}
\hline & \multicolumn{2}{c}{ Univariate } & \multicolumn{2}{c}{ Multivariate $^{2}$} \\
& OR & $(\mathbf{9 5 \%}$ CI & OR & $(\mathbf{9 5 \% ~ C I )}$ \\
\hline $\begin{array}{l}\text { How much does your illness affect } \\
\text { your life? }\end{array}$ & 1.46 & $(1.32-1.62)$ & 1.47 & $(1.31-1.65)$ \\
$\begin{array}{l}\text { How long do you think your illness } \\
\text { will continue? }\end{array}$ & 1.14 & $(1.05-1.25)$ & 1.16 & $(1.05-1.27)$ \\
$\begin{array}{l}\text { How much control do you feel you } \\
\text { have over your illness? }\end{array}$ & 0.69 & $(0.62-0.78)$ & 0.70 & $(0.61-0.79)$ \\
$\begin{array}{l}\text { How much do you think your } \\
\text { treatment can help your illness? }\end{array}$ & 0.84 & $(0.75-0.95)$ & 0.84 & $(0.74-0.95)$ \\
$\begin{array}{l}\text { How much do you experience } \\
\text { symptoms from your illness? }\end{array}$ & 1.65 & $(1.47-1.85)$ & 1.63 & $(1.44-1.84)$ \\
$\begin{array}{l}\text { How concerned are you about your } \\
\text { illness? }\end{array}$ & 1.24 & $(1.15-1.34)$ & 1.23 & $(1.14-1.34)$ \\
$\begin{array}{l}\text { How well do you feel you } \\
\text { understand your illness? }\end{array}$ & 1.00 & $(0.92-1.08)$ & 1.00 & $(0.92-1.09)$ \\
$\begin{array}{l}\text { How much does your illness affect } \\
\text { you emotionally? (e.g. does it make } \\
\text { you angry, scared, upset or } \\
\text { depressed? }\end{array}$ & 1.34 & $(1.24-1.45)$ & 1.36 & $(1.25-1.48)$ \\
\hline 'Confidence interval; ${ }^{2}$ adjusted for age, education and income & & \\
\hline
\end{tabular}




\subsection{Association of cognitive and emotional illness indicators and poor treatment adherence}

The associations of cognitive and emotional illness indicators and poor treatment adherence measured using three different scores in asthma patients in Latvia are presented in Table 4.6. None of the eight items of the brief IPQ was a statistically significant predictor of poor treatment adherence in any of the three adherence scores. Adjustment for age, education or income did not alter the results. 


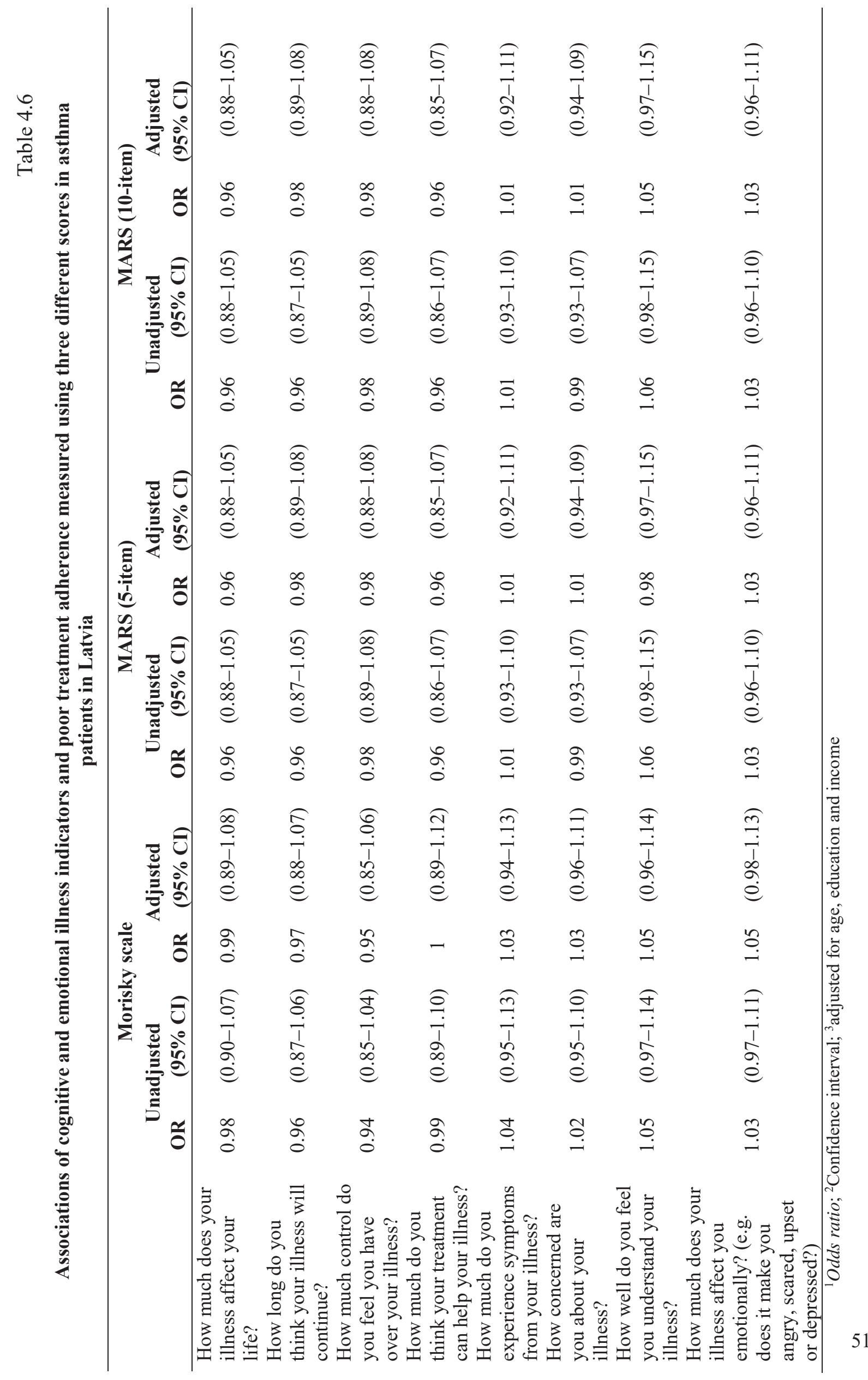




\subsection{Association between medication beliefs and poor treatment adherence}

Differences were found in regard associations between beliefs about medication and poor treatment adherence according to adherence scales (Table 4.7). Whereas beliefs about medication were not associated with poor treatment adherence on the MARS 10-item scale, several questions about necessity or concerns related to pharmaceutical treatment were able to predict poor adherence according to the Morisky scale (Table 4.8). If the patient felt that without his asthma medication his/her life would be impossible, his risk to have poor treatment adherence was $46 \%$ reduced (OR 0.54; 95\% Confidence interval (CI) 0.33-0.89). Furthermore, asthma patients who were convinced that their health depends on the asthma treatment were less likely to have poor treatment adherence (OR 0.56: 95\% CI 0.32-0.97). Each of the three concerns about medication questions was a statistically significant predictor of poor treatment adherence. In case the patient was concerned by the need to constantly use asthma medication or sometimes concerned by long-term effects of their asthma medication the odds of poor treatment adherence were 1.96 (95\% CI 1.19-3.24) and 2.43 (95\% CI 1.45-4.08), respectively. Furthermore, patients who felt that their asthma medication is incomprehensible to them had a two-fold increase in risk of poor treatment adherence. In regard MARS 5-item scale, only two variables were able to predict poor treatment adherence. The risk of poor adherence was $58 \%$ reduced (95\% CI $0.24-0.74)$ if the patients felt that their future health depends on their asthma medication. In addition, concerns about long-term effects of asthma medication increased the risk of poor treatment adherence two-fold $(95 \% \mathrm{CI}$ $1.22-3.27)$. 


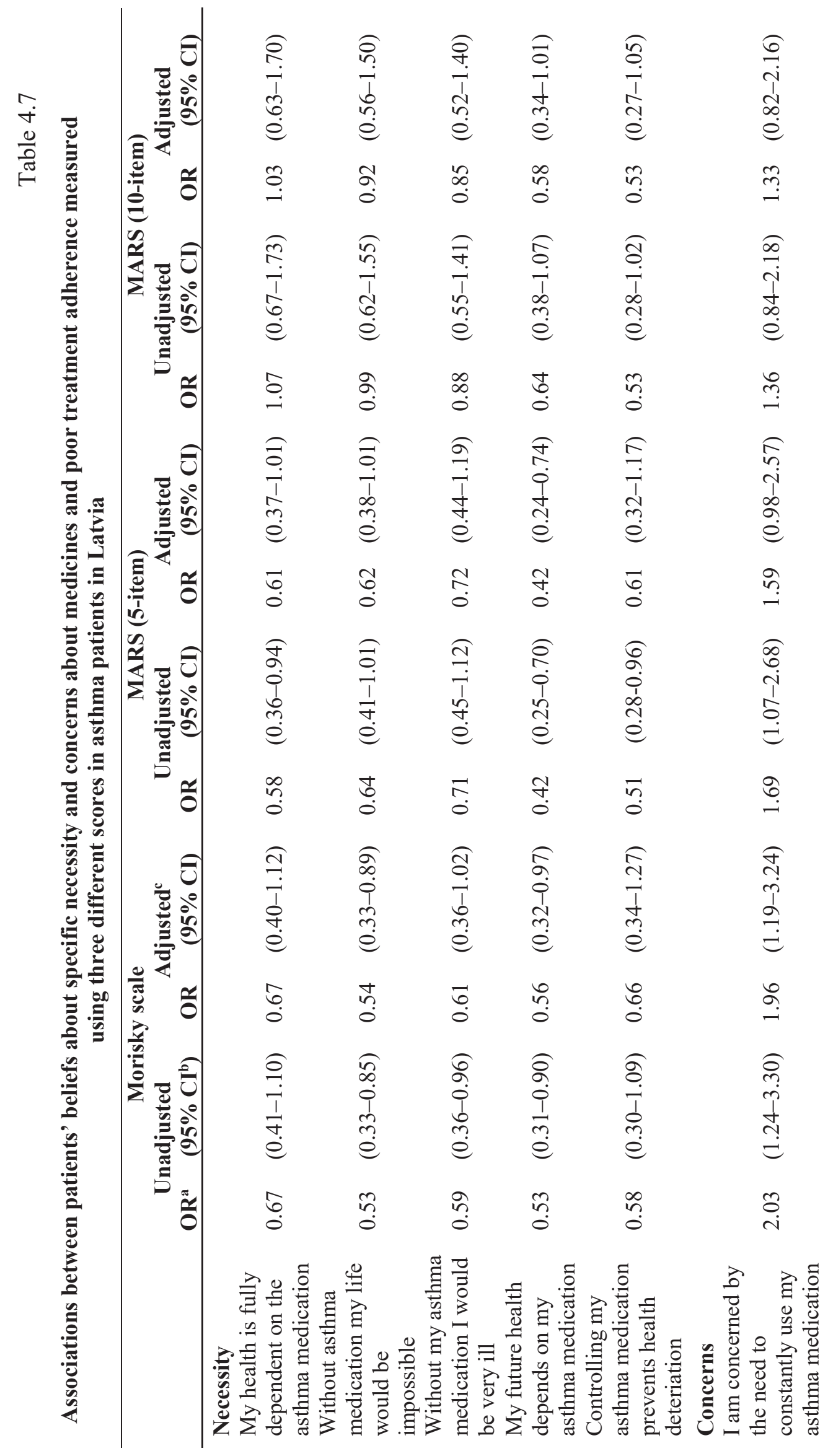




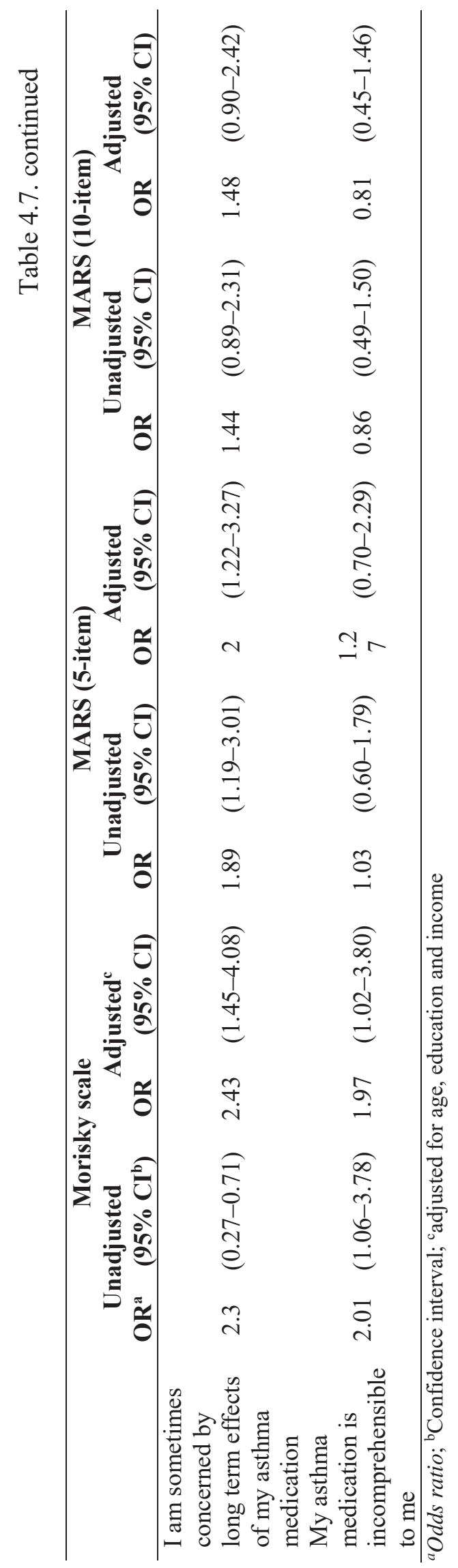




\section{DISCUSSION}

\subsection{Asthma control}

According to GINA global strategy for asthma management (Global Initiative for Asthma. Global Strategy for Asthma Management and Prevention, 2018) the level of asthma control is the extent to which manifestations of asthma can be observed in the patient, or have been modified by the treatment. It is determined by the interaction between the patient's genetic background, underlying disease processes, the treatment that they are taking, environment, and psychosocial factors. Asthma control has two domains: symptom control and future risk of adverse outcomes. Many studies describe discordance between the patient's and health provider's assessment of the patient's level of asthma control. It does not necessarily mean over- or underestimating disease control by a patient but the fact that patients and providers might understand the word "control" differently.

In our study, two out of three patients had poor asthma control measured by the ACT. Even though assessing asthma control with only symptoms and not clinical measurements usually overestimates the result, our estimates of poor asthma control is in line with previous findings from European studies revealing a prevalence of $49-76 \%$ of poor asthma control in various European populations (Rabe K. F, et al., 2000; Rabe K. F., et al., 2004; Cazzoletti L., et al., 2007; Fueyo A., Ruiz M. A., Ancochea J., Guilera M., Badia X., 2007). The AIRE study conducted in seven European countries (France, Germany, Italy, The Netherlands, Spain, Sweden, and UK) showed that just 5.3\% of all patients in European countries met all the GINA criteria for asthma control. $46 \%$ of patients reported daytime symptoms and $30 \%$ asthma-related sleep disturbances at least once a week (Rabe K. F, et al., 2000). A Spanish study on the other hand found a high number of patients with inadequate asthma control, with slightly higher figures in winter than in spring (74.4\% vs. 71\%) (Fueyo A., Ruiz M. A., Ancochea J., Guilera

M., Badia X., 2007). Furthermore, a cross-sectional study performed in 29 countries of America, Europe, and Asia on 7,786 adults' asthma reported that in Central and Eastern European close to $70 \%$ of asthma patients experienced that their disease limited their normal daily activities (Rabe K. F., et al., 2004). Finally, the European Community Respiratory Health Survey II reported that $85 \%$ of the asthmatic adults who had used ICS in the last 12 months were not able to achieve total control of the disease. Among those who had not used ICSs in the past year, the prevalence of uncontrolled asthma was 54\% (Cazzoletti L., et al., 2007). There have been no publications on asthma control in Latvia therefore we cannot compare our findings with earlier research in Latvian population. 


\subsection{Factors related to poor asthma control}

Our study showed that some beliefs of necessity of asthma medication as well as cognitive and emotional illness perception factors correlate well with poor asthma control in Latvian patients.

In general, limited evidence exists about associations between medication beliefs, illness perception and asthma control. The few studies that have assessed one of the above mentioned indicators were mainly conducted to test associations with treatment adherence related to specific medication such as corticosteroids but not with the control of the disease in general (Broadbent E., et al., 2006; Mann D., et al., 2009).

Nevertheless, our results are in line with those of other studies revealing an association between beliefs about illness, treatment and self-management of asthma (Horne R., 2006). Previous studies have also shown that individuals with asthma who believe that their medication is necessary for their present and future health or that it prevents exacerbation of their disease are more likely to have their asthma well controlled (Axelsson M., Ekerljung L., Lundbäck B., 2015). In contrast, individuals who are concerned about their asthma medication are more inclined to deviate from the prescribed treatment (Horne R., Weinman J., 2002; Menckeberg T. et al., 2008; Ponieman D., et al., 2009). Patients often make treatment choices according to their own understanding and beliefs about the illness and treatment (Horne R., et al., 2007). Patients' adherence to medication is particularly influenced by the way in which they evaluate their personal need for medication relative to their concerns about potential negative effects of taking it (Horne R., et al., 2007; Horne R., Weinman, J., 1999). This is in line with the results of our study indicating that asthma patients concerned about their medications had a 2-3 fold higher probability to have poor asthma control. Furthermore, a recent Australian study indicated that personal health beliefs about control can undermine adherence to medical and environmental remediation advice and likely contributes to high rates of uncontrolled asthma (George M., Keddem S., Barg F. K., Green S., Glanz K., 2015).

Our observation was that patients who reported necessity for medication had increased risk of poor asthma control almost three-fold. Poor disease control in patients who were convinced that their life fully depends on their medication and believed that without asthma medication life would be impossible or patient would be very ill might seem a paradox, since these patients are more adherent to their treatment. Indeed, according to our results, if the patient felt that without their asthma medication their life would be impossible, the risk to have poor treatment adherence was $46 \%$ reduced. For this observation we need to consider causality and approach it from the patient perspective. Poor asthma control is characterized by frequent 
symptoms and limitations in everyday life and such patients would feel that they are controlled by their disease and therefore dependent on the medication that fights their disease. Also, we need to acknowledge that these findings depend on patient self-report and we might not be aware of the specific deeper reasons for such patient opinions. The association between patient reports that their life fully depends on treatment and poor asthma control might have an important clinical value. Asking a patient the treatment necessity questions and receiving answers that indicate strong necessity might guide the doctor as an additional indication that the particular asthma patient might not be well controlled on the current pharmaceutical treatment. The necessity questions might therefore be used as an indirect indicator of disease control.

We somewhat unexpectedly found that asthma medication being incomprehensible was not associated with poor disease control. We might speculate that patients are not expecting to understand their medication and leave it to their doctor. Another explanation might be that the medical specialists rarely take time to explain medication to their patients and therefore we do not see differences in this parameter between patients whose disease is controlled or non-controlled.

\subsection{Prevalence of medical treatment adherence}

The three treatment adherence scales used in this study revealed that close to seven out of ten asthma patients in Latvia have poor treatment adherence. Our findings revealing that two out of three Latvian asthma patients have poor disease control are in line with previous findings indicating a prevalence of $49-76 \%$ of poor asthma control in the European population. However, the prevalence of poor adherence of Latvian asthma patients according to our study is 58 to $76 \%$ and one of the highest when compared with US and the European asthma patients where median adherence is $67 \%$ ranging from $40 \%$ in US to $78 \%$ in Iceland (Cerveri I., et al., 1999; Bender B. G., Bender S. E., 2005; Bender B. G., Long A., Parasuraman B., Tran Z. V., 2007).

Looking at differences between countries, a very high percentage of asthmatics had received an asthma medication prescription, at least once in their life, in almost all countries but the USA and Spain. In these two countries, the percentage of subjects who had never received a prescription for asthma seems to be particularly substantial, taking into account that the diagnosis of asthma was made by doctors. Another interesting result relates to the peculiar pattern of patient compliance in the USA and Australia: in these two countries, in fact, there is 
the lowest compliance with the highest prevalence of severe asthmatics. Asthma mortality represents a major problem in both countries; low compliance has been documented to be a risk factor for adult and childhood asthma deaths (Cerveri I., et al.1999; Taylor D. R., et al., 2008). Many studies have speculated about the possible determinants of this situation in the USA and Australia referring to difficulties in access to health care resources because of social, economic and geographical barriers (Cerveri I., et al.1999). It has to be kept in mind that a problem in interpreting reported variations in asthma adherence between different studies is related to the different precision of the estimates, due to the large difference across countries in the number of current asthmatics included in the studies, mainly reflecting differences in the number of centers participating in the different studies in each country and the size of the initial samples (Demoly P., Paggiaro P., Plaza V., et al., 2009; Leynaert B., Bousquet J., Neukirch C., Liard R., Neukirch F., 1999). Thus, there may be some heterogeneity within regions of different countries including Latvia. When comparing adherence levels between different countries and geographical regions we need to consider the aspects of financial and geographical access to healthcare. In our study we assessed associations of mixing factors such as sex, income levels and education with poor treatment adherence. There have been previous studies that look at some of these factors. A study in US assessed impact of a full reimbursement of medication used after myocardial infarction compared to a usual reimbursement plan (Choudhry N., et al., 2011). The results showed 4 to 6 percentage points higher adherence rate in the full-coverage group. Economic factors might be associated with adherence in the Latvian healthcare environment since the reimbursement level for asthma medication in Latvia is $75 \%$ of the price and that is lower compared to the majority of European countries. The resulting copayment level for reimbursed controller medications for asthma patients is $25 \%$ of the pharmacy price and amounts to 14,52 EUR per month for the most widely used medicine. This relatively high copayment for patients may have a negative effect on adherence to asthma medication in Latvia compared to other European countries.

There is limited information on adherence levels to asthma medication in Latvia. In a previous study we have analyzed data obtained from the National Health Service of reimbursed prescriptions of controller medication in 2013 for 100 patients (Šmits D, 2013). The adherence measure used was number of controller mediation prescriptions filled within 12 months period and divided by 12 months. We reported adherence level of $38 \%$ and calculation was based on average of 4.6 monthly doses of controller medication purchased within 12 months period. Although such calculation has its limitations, this finding is consistent with our current research. 


\subsection{Factors related to treatment adherence}

Patients' medication beliefs may explain a significant portion of variation in medication nonadherence in asthma patients (Phatak H. M., Thomas J 3rd, 2006). Our results in regard beliefs about medication and treatment adherence are in line with previous findings showing that beliefs about the necessity and concerns about side effects of asthma treatment are well associated with poor adherence (Horne R., Weinman J., 2002; Menckeberg T., et al., 2008; Leventhal H., et al., 2004; Clifford S., Barber N., Horne R., 2008). A British study in 100 community-based patients revealed that non-adherent behaviors were associated with doubts about the necessity of medication and concerns about its potential adverse effects (Horne R., Weinman J., 2002). Furthermore, a cross-sectional survey among 238 Dutch asthma patients also reported that self-reported adherence correlated significantly with necessity beliefs and concerns of chronic use of inhaled corticosteroids (Menckeberg T., et al., 2008). These beliefs and concerns against perceptions of necessity, have been found to predict adherence to medication not only in asthma patients but also in treatment of HIV, arthritis and coronary heart disease (Menckeberg T., et al., 2008; Clifford S., Barber N., Horne R., 2008; Horne R., et al., 2004; Neame R., Hammond A., 2005). In addition, current evidence suggests that certain beliefs about medicines are more predictive of intentional nonadherence than of unintentional nonadherence (Clifford S., Barber N., Horne R., 2008). For instance, in a study among asthma patients in New Zealand intentional nonadherence (missing or altering doses to suit one's needs) is associated with decision balance, whereas unintentional nonadherence (forgetting to take medication) is less strongly associated with decision balance and is more strongly associated with demographics, in particular age (Wroe A. L., 2002).

In our study we observed that older age decreased likelihood for poor adherence. It somewhat contradicts the observations from the study discussed above, however, we need to take into account that our study does not differentiate between intentional and non-intentional non-adherence. We may speculate that our results indicate that patients of older age are generally more compliant and respectful of the recommendations of medical specialists. There are anecdotal reports by doctors that younger patients are more willing to challenge doctor's advice and seek alternative information sources that influence their adherence decisions.

We would speculate that intentional non-adherence is more prominent in cases of chronic disease with mild or intermittent symptoms. Intentional adherence is explained by a psychological balance between necessity for treatment and concern about treatment.

For bronchial asthma patients during our interviews we have heard a question that impacts necessity beliefs - "do I have disease when I do not have symptoms"? 
In other words - if there is no disease between symptoms there is no necessity to use medicines. From patient perspective they are adherent but from healthcare provider and guideline perspective such patients are non-adherent. A possible explanation is the finding of our study that patients who felt that their asthma medication is incomprehensible to them had a two-fold increase in risk of poor treatment adherence. The underlying reason for this finding might be patient's lack of understanding what do their medication actually do, what are the roles and effects of reliever medications and controller medications. It might be an indication that medical professionals do not take enough time to explain to patients in a comprehensible way the nature of their disease, risks of airway remodeling if chronic inflammation is not adequately suppressed by controller medication.

Also, in our practice we have observed situations where nudges for intentional and nonintentional adherence are opposing. A once daily medication would usually increase adherence level due to ease of use, less likely forgotten doses. However, we have had cases where once daily dosing increase the concerns beliefs for patients based on view that an effective once a day medication has to be very strong and therefore potentially harmful. These anecdotal cases indicate that one must not oversimplify beliefs and behaviors balances for individual patients.

The self-regulatory model was developed in order to explain illness-related behavior, including adherence to treatment recommendations within the field of non-communicable diseases (Leventhal H., et al., 2004). According to that model adherence to treatment consists of several components that the patient can adopt to cope with their disease. Only a very few studies have assessed the association between illness perception and treatment adherence in asthma patients (Olszanecka-Glinianowicz M., Almgren-Rachtan A., 2014; Unni E., Shiyanbola O. O., 2016; Leventhal H., et al., 2004; Byer B., Myers L. B., 2000).

In contrast to our study, non-adherent behaviors were associated with more negative perceived consequences of illness in British asthma patients (Horne R., Weinman J., 2002; Byer B., Myers L. B., 2000). In their study, the number of preventer inhaler prescriptions was significantly associated with patient beliefs about the necessity of their asthma medication, and external cause; number of reliever inhaler prescriptions was significantly associated with belief in a long illness duration and high morbidity (Byer B., Myers L. B., 2000). Furthermore, a large Polish survey in 3,618 asthma patients, illness perception, younger age, disease duration and severity were predictors of adherence to treatment with fluticasone propionate and formoterol fumarate among patients with asthma (Olszanecka-Glinianowicz M., Almgren-Rachtan A., 2014). It has also been suggested that interventions focusing on illness perception helped to support chronic obstructive pulmonary disease patients in their disease management and to improve health-related quality of life (Weldam S. W., Lammers J. W., Heijmans M. J., 
Schuurmans M. J., 2014). More evidence is needed to show whether the same principle applies for asthma patients.

The health belief model tries to explain how beliefs about medicines affect ones behavior to take medication proposing that a patient chooses a certain behavior through a costbenefit analysis where the perceived benefits such as health improvements are compared against the perceived costs (Bender B. G., Long A., Parasuraman B., Tran Z. V., 2007; Horne R., Weinman, J., 1999). Unclear results have been published about whether necessity, concerns and the necessity-concern differential correlate with adherence in asthma patients (Menckeberg T. T., et al., 2008; Van Steenis M., et al., 2014; Byer B., Myers L. B., 2000; Janz, N. K., \& Becker, M. H., 1984). In contrast to our results, some studies assessing the associations of necessity, concerns and medication adherence in asthma patients revealed that only necessity beliefs were associated to medication adherence (Byer B., Myers L. B., 2000; Janz, N. K., \& Becker, M. H., 1984). There is a common sense origin of necessity beliefs. In our practice patients increasingly want to evaluate the advice based on their common sense. Patients want to avoid blindly following a medical advice even if it comes from a trustworthy and respected source. Missed doses of a controller medication do not make a patient feel immediately worse, neither do doses that a patient takes provide immediate tangible positive effect. Necessity beliefs are to some extent formed by understanding long-term and short-term consequences. Such understanding becomes the patient's "common sense".

We observed that monotherapy with corticosteroids reduced the odds of poor treatment adherence and that might seem a paradoxical result since fixed dose combination medicines of inhaled corticosteroid and bet 2 mimetic offer treatment effect that a patient can feel, whereas effects of plain corticosteroid a patient would not usually feel as it will reduce number of disease exacerbations over time. However, we may speculate that the symptom relieving effect of the beta 2 mimetic component of the medicine is indeed causing non-adherent behavior. Patients would feel their symptom relief brought by the beta 2 mimetic component of their medicine and decide that their disease is not that severe anymore and the resulting action would be taking less medicine.

Byer et al found that self-reported adherence was significantly positively correlated with the necessity in 64 asthma patients from a general practice in Leicester, UK (Janz, N. K., \& Becker, M. H., 1984). In addition, they also reported a correlation between illness perception and medical adherence. Another study in 93 patients aged 18-80 years who filled at least two ICS prescriptions showed that necessities were positively related to self-reported adherence suggesting that it could be more important to focus on necessities than on concerns in an attempt to improve adherence (Byer B., Myers L. B., 2000). In line with our results, Menckeberg et al 
showed a positive relationship between the necessity-concerns differential and adherence indicating that having stronger beliefs about the necessity of treatment compared to concerns about negative consequences may increase adherence (Menckeberg T. T., et al., 2008; Van Steenis M., et al., 2014).

A possible explanation of the contradictory results may be related to the power of the study. Most of the previous studies had a much lower sample size lacking power to detect an association between concerns and medical adherence given that most likely the association between necessity and medical adherence may be stronger than for concerns and adherence. A recent meta-analysis suggested that necessity and concern beliefs about medicines are one important factor to consider when understanding reasons for non-adherence in chronic disease patients (Emilsson M., et al., 2011). Furthermore, they highlighted that the effect size for necessity was stronger in asthma and weaker in the cardiovascular group compared to the overall effect size. However, this may also reflect the difference in symptomatic vs asymptomatic conditions of the diseases. An earlier meta-analysis by Horne et al found a statistical significant association between necessity and concern beliefs and medication adherence even when stratified by country, sample size and type of adherence measure used (Foot H., La Caze A., Gujral G., Cottrell N., 2016).

\subsection{Adherence scales as predictor of asthma adherence}

There are many self-report scales for measuring medication adherence. It was of surprise that the combined use of corticosteroids and beta 2 mimetics using the MARS (5-item) showed a lower adherence than corticosteroids as it would have been expected that the clinical effect of combination therapy would favor adherence. As this finding was only observed in the MARS (5-item) and not in the MMAS or MARS (10-item), we hypothesize that the MARS (5-item) may be inferior due to the additional elements/dimensions included in the other two scales.

Due to the different nature of the diseases, there is no gold standard scale for measuring medication adherence (Culig J., Leppee M., 2014; Horne S. C., et al., 2013). Our study showed the best associations between the necessity-concern framework with the Morisky scale but not with the MARS scale. The MARS scale has revealed adequate reliability but its validity seems to be only moderate-weak (Culig J., Leppee M., 2014; Horne S. C., et al., 2013). It has been suggested that though the internal consistency of the MARS could be improved either by adding more response options or by adding more items, it is debatable whether this would constitute 
an improvement to the measure, or whether it would compromise its quick, simple format (Horne S. C., et al., 2013). Items in the MARS about attitude to medication may be informative to clinicians identifying barriers to adherence in individual cases, but do not appear to be valuable in predicting adherence behavior over a large sample (Culig J., Leppee M., 2014). Culig et al conducted a systematic review identifying articles on scales for medication adherence measuring (Culig J., Leppee M., 2014). They concluded that the most frequently used one and nearest to gold-standard is the MMAS. Thus, according to our results and those of previous studies, we suggest to use the MMAS in Latvian asthma patients as a tool to assess medical adherence.

\subsection{Limitations}

Several limitations need to be considered in this study. Asthma control was measured by a self-report questionnaire not previously validated in the Latvian population. Clinical measurements of asthma control may be more precise and objective. However, the ACT has been successfully validated in other studies consisting of a similar population to ours and has shown to be well correlated with baseline per cent predicted forced expiratory volume (Schatz M., et al., 2006). Thus, the ACT may correlate well with forced expiratory volume in the Latvian population as well. In addition, as this study is cross-sectional in design, no conclusions on causality can be drawn. Finally, even though the patients of this study were recruited from the main towns and the capital city where more than $25 \%$ of the total Latvian population live, the results cannot be generalized to the overall population of Latvian asthma patients.

Asthma medication adherence was measured by self-report questionnaires not previously validated in the Latvian population. Even though the Morisky Medication Adherence Scale and the MARS 10-item scales have been successfully validated in other studies (Krousel-Wood M., et al., 2013; Thompson K., Kulkarni J., Sergejew A. A., 2002; Krapek K., et al., 2014; Cochrane G. M., Horne R., Chanez P., 1999), self-reported measurements of medication adherence may not be that precise and still subject to selfpresentational and recall bias overestimating adherence. Furthermore, asthma control was measured by a self-administered questionnaire. Moreover, it has to be mentioned that a general issue not addressed by self-reported adherence questionnaires is inhaler technique which is an essential part of good adherence implementation(Vrijens B., et al., 2016). The challenges faced when using inhaled medications can include a combination of delivery issues (eg, knowing the sequence of steps required to use the inhaler correctly, successful dose preparation, inspiratory flow rate, and in pressurized metered-dose inhalers, dose actuation and coordination with breath 
inhalation); practical issues (eg, integration and scheduling with coexisting medications, storage, and device cleaning); and psychosocial challenges (eg, self-consciousness about inhaler use in public) (Giraud V., Roche N., 2002; Vrijens B., et al., 2016; Westerik J. A., et al., 2016). Thus, it may be worthwhile developing and validating treatment adherence questionnaires that take into account these important factors. Finally, the findings of our study may only be valid for a more severe patient population: those patients referred to a pulmonologist and, thus, do not necessary represent those seen in regular primary health-care. These patients may already have some issues in regard adherence as it is the most common cause of disease control.

Then, pulmonologists in medical centers and hospitals in Riga and in bigger towns of Latvia were invited to join the study and 15 of these practices agreed to participate (convenience sample). These practices employ 66 pneumonologists that constitute $51 \%$ of all 129 pneumonologists in Latvia that are in legal relationship with the National Health Service of Latvia and we assumed these 15 practices to be representative of all pulmonologist practices in Latvia although this also represents a selection bias. 


\section{CONCLUSIONS}

1. Demographic and socio-economic factors (age, sex, education and income) were not associated with disease control and treatment adherence.

2. Acceptance of necessity of asthma treatment and concern about the need to constantly use asthma medication were associated with increased likelihood of poor asthma control.

3. Medication beliefs, particularly concerns and necessity of asthma treatment when assessed with BMQ scale were associated with poor treatment adherence when assessed with the Morisky or 5-item MARS scale.

4. Several cognitive and emotional illness indicators predicted poor asthma control in the study patients.

5. Beliefs about asthma treatment, cognitive and emotional factors were not associated with treatment adherence.

6. None of the tested asthma treatment adherence scales were able to predict poor asthma control in Latvian patients.

We recommend to use either the MMAS or the 5-item MARS scale in Latvian asthma patients to identify patients with poor treatment adherence. Thus, it may be worthwhile to assess routinely the concerns and necessity of asthma medication in patients within the Latvian health-care system to improve treatment adherence in that vulnerable population group to improve treatment outcomes. 


\section{PRACTICAL APPLICATIONS}

\section{Implications for clinical practice}

The development of more effective methods for addressing nonadherence is a priority for research and practice (NAEPP (National Asthma Education and Prevention Program), 2017; Haynes R. B., et al., 2002). Horne and colleagues found that novel interventions to support informed choice and optimal adherence to appropriately prescribed medicines are likely to be more effective if they take account of patients' beliefs about the treatment and how they judge their personal need for the prescription relative to concerns about potential adverse consequences of taking it (Horne S. C.,et al., 2013). Beliefs can have counter-balancing effects on adherence, such as when patients continue to take a medication they believe is essential for their health despite concerns regarding adverse effects (Maidment R., Livingston G., Katona C., 2002). The challenge now is to develop effective interventions to address patients' doubts about the necessity for treatment and concerns about adverse consequences in order to enhance adherence (Horne S. C.,et al., 2013). The challenge goes beyond 'getting patients to take more medicines'. Many patients harbor significant, unresolved doubts and concerns about prescribed treatment suggesting a fault-line between patients' and prescribers' cultural perceptions of the treatment (Horne S. C.,et al., 2013). Viewed from the patients' perspective, nonadherence may be a 'common-sense' response to their implicit appraisal of the treatment. For some patients nonadherence might represent an informed choice. In this case the outcome of 'adherence support' would be to avoid prescribing an unwanted treatment, to the relief of patient and payer (Horne S. C., et al., 2013). However, for others, evaluations of treatment necessity and concerns may be based on misconceptions about the illness and treatment. More detailed studies of patient representations illness and treatment show that, even when treatment evaluations are based on misconceptions they appear to draw on a 'common-sense' logic (Leventhal H., Phillips L. A., Burns E., 2016; Kleinman A., 1986). For example, the need for daily medication may seem less salient when symptoms are absent or cyclical (Horne R., Weinman J., 2002; Horne R., et al., 2007; Horne R., Weinman, J., 1999). Concerns about prescribed medication are not just related to side effects but are common, even when the medication is well tolerated. They are often related to beliefs about the negative effects of medication and include worries about long-term effects, dependence, cost of medication and dislike of having to rely on medicines (Horne R., Weinman, J., 1999; Horne R., Weinman, J, Hankins M., 1999). Concerns are related to more general beliefs about pharmaceuticals as a class of treatment which are often perceived as intrinsically harmful and over-prescribed by doctors (Horne R., et al., 2007; Horne 
R., Weinman, J., 1999; Horne S. C., et al., 2013; Calnan M., Montaner D., Horne R., 2005). The package information leaflets, dispensed with many prescription medicines may exacerbate concerns as they list all possible side effects, leaving patients with outstanding questions and making it difficult to understand the likely risk and place them in context with potential benefits (Bowskill R., et al., 2007). Non-adherence is often a hidden problem. Patients may be reluctant to express doubts or concerns about prescribed medication and to report nonadherence; sometimes because they fear that this will be perceived by the prescriber as a lack of faith in them (Horne S. C., et al., 2013). The first step to facilitating adherence is therefore to take a no-blame approach' and encourages an honest and open discussion to identify non-adherence and the reasons for nonadherence (Horne S. C., et al., 2013). Adherence support should be tailored to the needs of the individual addressing perceptions (e.g. necessity beliefs and concerns) as well as practicalities (e.g. capacity and resources). This can be approached in a three stage process: 1) communicating a common-sense rationale for personal need that takes account of the patient's perceptions of the illness and symptoms expectations and experiences 2) eliciting and addressing specific concerns and 3) making the treatment as convenient and as easy to use a possible (Clifford S., Barber N., Horne R., 2008; Horne S. C., et al., 2013). Interventions attempting to improve adherence by applying these approaches have had encouraging result (Clifford S., Barber N., Horne R., 2008; Elliott R., et al., 2008).

Finally, non-adherence remains a problem in clinical practice. Consideration of patients' perceptions of treatment necessity and concerns in prescribing and treatment review is essential to support informed choice and optimal adherence to appropriately prescribed treatment.

A Cochrane systematic review postulates that increasing the effectiveness of adherence intervention may have a far greater impact on the health of the population than any improvement in specific medical treatments. The difficulty is in selecting an intervention that will work for a patient with specific beliefs and behaviors. Existing questionnaires assessing beliefs of medication necessity, cognitive or emotional illness perception may be used to identify patients with poor asthma control, in order to help them to identify problems of poor control and offering better treatment solutions. If these tools were integrated within the pulmonologist practices where the vast majority of asthma patients receive their initial disease diagnosis and treatment initiation, they could help in designing individualized asthma treatment plans, and thus reduce the short and long term complications of asthma improving the quality of life of asthma patients.

In clinical practice it is important to recognize that non-adherence is common and most if not all patients are at times non-adherent. Routine assessment during prescribing and/or 
dispensing medicines is recommended. Adherence can be improved but there will not be a "one-size-fits-all" solution and approach towards fixing an adherence issue has to be patient tailored. Healthcare professionals will improve their patients adherence if they will adapt their consultation style to fit an individual patient and will take effort to engage patient into decision making according to their wishes. 


\section{ACKNOWLEDGMENTS}

I want to thank students of the Faculty of Medicine of Rīga Stradinšs University for assisting me to perform the interviews: Dana Kigitoviča, Alīna Ivakina, Kārlis Stirāns, Renāte Būmane, Laura Bubko. The research was supported by a grant from Rīga Stradinšs University. 


\section{REFERENCES}

1. Adams, R. J., Fuhlbrigge, A., Guilbert, T., Lozano, P., Martinez, F. 2002. Inadequate use of asthma medication in the United States: results of the Asthma in America national population survey. J Allergy Clin Immunol. 110, 58-64.

2. Adherence to medical plans for older people. A European Innovation Partnership on Active and Healthy Ageing priority.

https://ec.europa.eu/health//sites/health/files/ageing/docs/medicalplans olderpeople en.pdf. [viewed 15.03.2018]

3. Ahmed, S., Ernst, P., Tamblyn, R., Colman, N. 2007. Validation of The 30 Second Asthma Test as a measure of asthma control. Can Respir J. 14(2), 105-109.

4. Allegra, L., Cremonesi, G., Girbino, G., et al. 2012. Real-life prospective study on asthma control in Italy: cross-sectional phase results. Respiratory Medicine. 106(2), 205-214.

5. Annesi-Maesano, I., Oryszczyn, M. P., Raherison, C., et al. 2004. Increased prevalence of asthma and allied diseases among active adolescent tobacco smokers after controlling for passive smoking exposure. A cause for concern? Clin Exp Allergy. 34(7), 1017-1023.

6. Apter, A. J., Boston, R. C., George, M., Norfleet, A. L., Tenhave, T., Coyne, J. C., Birck, B., et al. 2003. Modifiable barriers to adherence to inhaled steroids among adults with asthma: it's not just black and white. J Allergy Clin Immunol. 111(6), 1219-1226.

7. Armour, C. L., Lemay, K., Saini, B., et al. 2011. Using the community pharmacy to identify patients at risk of poor asthma control and factors which contribute to this poor control. J Asthma. 48(9), 914-922.

8. Armour, C. L., Reddel, H. K., LeMay, K. S., et al. 2013. Feasibility and effectiveness of an evidencebased asthma service in Australian community pharmacies: a pragmatic cluster randomized trial. J Asthma. 50(3), 302-309.

9. Axelsson, M., Ekerljung, L., Lundbäck, B. 2015. The Significance of Asthma Follow-Up Consultations for Adherence to Asthma Medication, Asthma Medication Beliefs, and Asthma Control. Nurs Res Pract. 139070.

10. Barber, N., Parsons, J., Clifford, S., Darracott, R., Horne, R. 2004. Patients' problems with new medication for chronic conditions. Qual Saf Health Care. 13(3), 172-175.

11. Bateman, E. D., Boushey, H. A., Bousquet, J., et al. 2004. Can guideline-defined asthma control be achieved? The Gaining Optimal Asthma ControL study. Am J Respir Crit Care Med. 170(8), 836-844.

12. Bateman, E. D., Bousquet, J., Keech, M. L., et al. 2007. The correlation between asthma control and health status: the GOAL study. The European Respiratory Journal. 29(1), 56-62.

13. Bateman, E. D., Hurd, S. S., Barnes, P. J., et al. 2008. Global strategy for asthma management and prevention: GINA executive summary. Eur Respir J. 31, 143-178.

14. Bender, B. G., Bender, S. E. 2005. Patient-identified barriers to asthma treatment adherence: responses to interviews, focus groups, and questionnaires. Immunol Allergy Clin North Am. 25(1), 107-130.

15. Bender, B. G., Long, A., Parasuraman, B., Tran, Z. V. 2007. Factors influencing patient decisions about the use of asthma controller medication. Ann Allergy Asthma Immunol. 98, 322-328

16. Benito-Fernández, J., Mojica-Muñoz, E., Andrés-Olaizola, A., et al. 2013. Impact on quality of life by improving asthma control medication in patients with persistent asthma in a paediatric emergency department. Eur J Emerg Med. 20(5), 350-355.

17. Boulet, L. P., Phillips, R., O'Byrne, P., Becker, A. 2002. Evaluation of asthma control by physicians and patients: Comparison with current guidelines. Can Respir J. 9, 417-423.

18. Bousquet, J., Clark, T. J., Hurd, S., et al. 2007. GINA guidelines on asthma and beyond. Allergy. 62, $102-112$.

19. Bousquet, J., Khaltaev, N., Cruz, A. A., et al. 2008. Allergic Rhinitis and its Impact on Asthma (ARIA) 2008 update (in collaboration with the World Health Organization, GA(2)LEN and AllerGen). Allergy. 63(Suppl. 86), 8-160.

20. Bousquet, J., Mantzouranis, E., Cruz, A. A, et al. 2010. Uniform definition of asthma severity, control, and exacerbations: document presented for the World Health Organization Consultation on Severe Asthma. J Allergy Clin Immunol. 126, 926-938.

21. Bowskill, R., Clatworthy, J., Parham, R., Rank, T., Horne, R. 2007. Patients' perceptions of information received about medication prescribed for bipolar disorder: Implications for informed choice. Journal of Affective Disorders. 100, 253-257.

22. Braido, F. 2013. Failure in asthma control: reasons and consequences. Scientifica (Cairo). 2013, 54925. 
23. Braunstahl, G. J., Kleinjan, A., Overbeek, S. E., Prins, J. B., Hoogsteden, H. C., Fokkens, W. J. 2000. Segmental bronchial provocation induces nasal inflammation in allergic rhinitis patients. Am J Respir Crit Care Med. 161(6), 2051-2057.

24. Broadbent, E., Patrie, K.J., Main, J., Weinman, J. 2006. The brief illness perception questionnaire. Journal of Psychosomatic Research. 60, 631-637.

25. Brown, M. T., Bussell, J. K. 2011. Medication adherence: WHO cares? Mayo Clinic Proceedings. 86(4), 304-314.

26. Byer, B., Myers, L. B. 2000. Psychological correlates of adherence to medication in asthma. Psychology, Health \& Medicine. 5(4), 389-393.

27. Calnan, M., Montaner, D., Horne, R. 2005. How acceptable are innovative health-care technologies? A survey of public beliefs and attitudes in England and Wales. Social Science \& Medicine. 60, 1937-1948.

28. Cameron, L. D., Leventhal, H. 2003. Self-regulation, health and illness. An overview. In L.D. Cameron $\&$ H. Leventhal (Eds.). The Self-regulation of healthy and illness behavior. Routledge. 1-13.

29. Cazzoletti, L., Marcon, A., Janson, C., et al. 2007. Asthma control in Europe: a real-world evaluation based on an international population-based study. Journal of Allergy and Clinical Immunology. 120(6), 1360-1367.

30. Cerveri, I., Locatelli, F., Zoia, M. C., et al. 1999. International variations in asthma treatment compliance: the results of the European Community Respiratory Health Survey (ECRHS). Eur Respir J. 14(2), 288-294.

31. Chalmers, G. W., Macleod, K. J., Little, S. A., Thomson, L. J., McSharry, C. P., Thomson, N. C. 2002. Influence of cigarette smoking on inhaled corticosteroid treatment in mild asthma. Thorax. 57(3), 226-230.

32. Chapman, K. R., Boulet, L. P., Rea, R. M., Franssen, E. 2008. Suboptimal asthma control: prevalence, detection and consequences in general practice. European Respiratory Journal. 31(2), 320-325.

33. Chen, H., Gould, M. K., Blanc, P. D., et al. 2007. Asthma control, severity, and quality of life: quantifying the effect of uncontrolled disease. Journal of Allergy and Clinical Immunology. 120(2), 396-402.

34. Chiu, K. C., Boonsawat, W., Cho, S. H, et al. 2014. Patients' beliefs and behaviors related to treatment adherence in patients with asthma requiring maintenance treatment in Asia. J Asthma. 51(6), 652-659.

35. Choudhry, N., Avorn, J., M. D., Glynn, R., Antman, E., Schneeweiss, S., Toscano, M., Reisman, L., Fernandes, J., Spettell, C., Lee, J., Levin, R., Brennan, T., Shrank, W. 2011. Full Coverage for Preventive Medications after Myocardial Infarction. N Engl J Med. 365, 2088-2097.

36. Christensen, A. J. 2004. Patient Adherence to Medical Treatment Regimens: Bridging the Gap between Behavioral Science and Biomedicine, Current Perspectives in Psychology, Yale University Press, New Haven, Conn, USA.

37. Clifford, S., Barber, N., Horne, R. 2008. Understanding different beliefs held by adherers, unintentional nonadherers, and intentional nonadherers: application of the Necessity-Concerns Framework. J Psychosom Res. 64, 41-46.

38. Cloutier, M. M., Schatz, M., Castro, M., et al. 2012. Asthma outcomes: composite scores of asthma control. J Allergy Clin Immunol. 129 (3 Suppl), S24-33.

39. Cochrane, G. M., Horne, R., Chanez, P. 1999. Compliance in asthma. Respir Med. 93, 763-769.

40. Cohen, J. L., Mann, D. M., Wisnivesky, J. P., Home, R., Leventhal, H., Musumeci-Szabó, T. J., Halm, E. A. 2009. Assessing the validity of self-reported medication adherence among inner-city asthmatic adults: the Medication Adherence Report Scale for Asthma. Ann Allergy Asthma Immunol. 103(4), $325-331$.

41. Cooper, V., Metcalf, L., Versnel, J., Upton, J., Walker, S., Horne, R. 2015. Patient-reported side effects, concerns and adherence to corticosteroid treatment for asthma, and comparison with physician estimates of side-effect prevalence: a UK-wide, cross-sectional study. NPJ Prim Care Respir Med. 25, 15026.

42. Correia de Sousa, J., Pina, A., Cruz, A. M., et al. 2013. Asthma control, quality of life, and the role of patient enablement: a cross-sectional observational study. Prim Care Respir J. 22(2), 181-187.

43. Corren, J., Adinoff, A. D., Irvin, C. G. 1992. Changes in bronchial responsiveness following nasal provocation with allergen. J Allergy Clin Immunol. 89(2), 611-618.

44. Culig, J., Leppee, M. 2014. From Morisky to Hill-bone; self-reports scales for measuring adherence to medication. Collegium Antropologicum. 38(1), 55-62.

45. Demoly, P., Paggiaro, P., Plaza, V., et al. 2009. Prevalence of asthma control among adults in France, Germany, Italy, Spain and the UK. European Respiratory Review. 18(112), 105-112. 
46. Elliott, R., Barber, N., Clifford, S., Horne, R., Hartley, E. 2008. The cost effectiveness of a telephonebased pharmacy advisory service to improve adherence to newly prescribed medicines. Pharmacy World \& Science. 30, 17-23.

47. Emilsson, M., Berndtsson, I., Lötvall, J., Millqvist, E., Lundgren, J., Brink E. et al. 2011. The influence of personality traits and beliefs about medicines on adherence to asthma treatment. Prim. Care Respir. J. 20, 141-147.

48. Ernst, P., Fitzgerald, J. M., Spier, S. 1996. Canadian Asthma Consensus Conference: Summary of recommendations. Can Respir J. 3, 101-114.

49. Fabbri, L. M., Boulet, L. P., Kardos, P., Vogelmeier, C. 2004. The asthma management gap - why current treatment strategies can fail to provide optimal asthma control. Int J Clin Pract. 58, 1-8.

50. Farmer, K. C. 1999. Methods for measuring and monitoring medication regimen adherence in clinical trials and clinical practice. Clinical Therapeutics. 21(6), 1074-1090.

51. Fischer, M. A., Stedman, M. R., Lii, J., et al. 2010. Primary medication non-adherence: analysis of 195,930 electronic prescriptions. Journal of General Internal Medicine. 25(4), 284-290.

52. Foot, H., La Caze, A., Gujral, G., Cottrell, N. 2016. The necessity-concerns framework predicts adherence to medication in multiple illness conditions: A meta-analysis. Patient Educ Couns. 99(5), 706-717.

53. Fueyo, A., Ruiz, M. A., Ancochea, J., Guilera, M., Badia, X., ESCASE Group. 2007. Asthma control in Spain. Do season and treatment pattern matter? The ESCASE study. Respir Med. 101, 919-924.

54. George, M., Birck, K., Hufford, D. J., Jemmott, L. S., Weaver, T. E. 2006. Beliefs about asthma and complementary and alternative medicine in low-income inner-city African-American adults. $J$ Gen Intern Med. 21(12), 1317-1324.

55. George, M., Freedman, T. G., Norfleet, A. L., Feldman, H. I., Apter, A. J. 2003. Qualitative researchenhanced understanding of patients' beliefs: results of focus groups with low-income, urban, African American Adults with asthma. J Allergy Clin Immunol. 111(5), 967-973.

56. George, M., Keddem, S., Barg, F. K., Green, S., Glanz, K. 2015. Urban adults' perceptions of factors influencing asthma control. Journal of Asthma. 52(1), 98-104.

57. Georgiou, A., Pearson, M. 2002. Measuring outcomes with tools of proven feasibility and utility: the example of a patient-focused asthma measure. J Eval Clin Pract. 8, 199-204.

58. Giraud, V., Roche, N. 2002. Misuse of corticosteroid metered-dose inhaler is associated with decreased asthma stability. Eur Respir J. 19(2), 246-251.

59. Global Initiative for Asthma (GINA). Pocket guide for asthma management and prevention. Bethesda: National Institutes of Health, National Heart, Lung, and Blood Institute. 1998. Publication No. 953659B.

60. Global Initiative for Asthma. Global Strategy for Asthma Management and Prevention, 2017. Available from: www.ginasthma.org [viewed 20.09.2017]

61. Global Initiative for Asthma. Global Strategy for Asthma Management and Prevention, 2018. www.ginaasthma.org. [viewed 15.03.2018]

62. Gruffydd-Jones, K., Hollinghurst, S., Ward, S., Taylor, G. 2005. Targeted routine asthma care in general using telephone triage. Br J Gen Pract. 55, 918-923.

63. Haselkorn, T., Chen, H., Miller, D. P., et al. 2010. Asthma control and activity limitations: insights from the Real-world Evaluation of Asthma Control and Treatment (REACT) Study. Annals of Allergy, Asthma and Immunology. 104(6), 471-477.

64. Haughney, J., Price, D., Kaplan, A., et al. 2008. Achieving asthma control in practice: understanding the reasons for poor control. Respir Med. 102, 1681-1693.

65. Haynes R. B., McDonald H., Garg A. X., Montague P. Interventions for helping patients to follow prescriptions for medications // Cochrane Database Syst Rev, 2002; 2: CD000011

66. Ho, P. M., Bryson, C. L., Rumsfeld, J. S. 2009. Medication adherence: its importance in cardiovascular outcomes. Circulation. 119(23), 3028-3035.

67. Horne, R. 2006. Compliance, adherence, and concordance: implications for asthma treatment. Chest. $130,65 \mathrm{~S}-72 \mathrm{~S}$.

68. Horne, R., Buick, D., Fisher, M., et al. 2004. Doubts about necessity and concerns about adverse effects: identifying the types of beliefs that are associated with non-adherence to HAART. Int J STD AIDS. $15,38-44$.

69. Horne, R., Clatworthy, J., Hankins, M.; ASCOT Investigators. 2010. High adherence and concordance within a clinical trial of antihypertensives. Chronic Illn. 6(4), 243-251. 
70. Horne, R., Graupner, L., Frost, S., Weinman, J., Wright, S. M., Hankins, M. 2004. Medicine in a multicultural society: the effect of cultural background on beliefs about medications. Soc Sci Med. 59(6), 1307-1313.

71. Horne, R., Price, D., Cleland, J., Costa, R., Covey, D., Gruffydd-Jones, K. 2007. Can asthma control be improved by understanding the patient's perspective? BMC Pulm Med. 7, 8.

72. Horne, R., Weinman, J. 1999. Patients' beliefs about prescribed medicines and their role in adherence to treatment in chronic physical illness. Journal of Psychosomatic Research. 47, 555-567.

73. Horne, R., Weinman, J. 2002. Self-regulation and Selfmanagement in Asthma: Exploring the Role of Illness Perceptions and Treatment Beliefs in Explaining Non-adherence to Preventer Medication. Psychology \& Health. 17(1), 17-32.

74. Horne, R., Weinman, J., Hankins, M. 1999. The beliefs about medicines questionnaire: The development and evaluation of a new method for assessing the cognitive representation of medication. Psychology \& Health. 14, 1-24.

75. Horne, S. C., Chapman, E., Parham, R., Freemantle, N., Forbes, A., Cooper, V. 2013. Understanding analytic review of the necessity-concerns framework. PLoS One. 8, e80633.

76. Hoskins, G., Williams, B., Jackson, C., Norman, P., Donnan, P. 2011. Assessing asthma control in UK primary care: use of routinely collected prospective observational consultation data to determine appropriateness of a variety of control assessment models. BMC Fam Pract. 12, 10.

77. Hylkema, M. N., Sterk, P. J., de Boer, W. I., Postma, D. S. 2007. Tobacco use in relation to COPD and asthma. Eur Respir J. 29(3), 438-445.

78. Janz, N. K., \& Becker, M. H. 1984. The health belief model: a decade later. Health Educ. Behav. 11, $1-47$.

79. Jimmy, B., Jose, J. 2011. Patient medication adherence: measures in daily practice. Oman Medical Journal. 26(3), 155-159.

80. Johnson, M. J., Williams, M., Marshall, E. S. 1999. Adherent and nonadherent medication-taking in elderly hypertensive patients. Clinical Nursing Research. 8(4), 318-335.

81. Jones, K. P., Bain, D. J. G., Middleton, M., Mullee, M. A. 1992. Correlates of asthma morbidity in primary care. BMJ. 304, 361-364.

82. Jones, K. P., Charlton, I. H., Middleton, M., Preece, W. J., Hill, A. P. 1992. Targeting asthma care in general practice using a morbidity index. BMJ. 304, 1353-1359.

83. Juniper, E. F., Bousquet, J., Abetz, L., Bateman, E. D. 2006. GOAL Committee. Identifying 'wellcontrolled' and 'not well-controlled' asthma using the Asthma Control Questionnaire. Respir Med. 100(4), 616-621.

84. Juniper, E. F., O’Byrne, P. M., Roberts, J. N. 2001. Measuring asthma control in group studies: do we need airway calibre and rescue $\beta 2$-agonist use? Respir Med. 95, 319-323.

85. Juniper, E. F., O'Byrne, P. M., Guyatt, G. H., Ferrie, P. J., King, D. R. 1999. Development and validation of a questionnaire to measure asthma control. Eur Respir J. 14(4), 902-907.

86. Juniper, E. F., Svensson, K., Mörk, A. C., Ståhl, E. 2005. Measurement properties and interpretation of three shortened versions of the asthma control questionnaire. Respir Med. 99(5), 553-558.

87. Katz, P. P., Yelin, E. H., Eisner, M. D., Blanc, P. D. 2002. Perceived control of asthma and quality of life among adults with asthma. Ann Allergy Asthm Immunol. 89, 251-258.

88. Kerstjens, H. A., Overbeek, S. E., Schouten, J. P., Brand, P. L., Postma, D. S. 1993. Airways hyperresponsiveness, bronchodilator response, allergy and smoking predict improvement in $\mathrm{FEV}_{1}$ during long-term inhaled corticosteroid treatment. Dutch CNSLD Study Group. Eur Respir J. 6(6), 868-876.

89. Khalili, B., Boggs, P. B., Shi, R., Bahna, S L. 2008. Discrepancy between clinical asthma control assessment tools and fractional exhaled nitric oxide. Annals of Allergy, Asthma and Immunology. 101(2), $124-129$.

90. Kim, M. T., Hill, M. N., Bone, L. R., Levine, D. M. 2000. Development and testing of the Hill-Bone Compliance to High Blood Pressure Therapy Scale. Progress in cardiovascular nursing. 15(3), 90-96.

91. Kleinman, A. 1986. Illness meanings and illness behaviour. In: McHugh S., Vallis T. M., editors. Illness behavior: A multidisciplinary model. New York: Plenum Press. 149-160.

92. Koster, E. S., Philbert, D., Winters, N. A., Bouvy, M. L. 2015. Adolescents' inhaled corticosteroid adherence: the importance of treatment perceptions and medication knowledge. J Asthma. 52(4), 431-436.

93. Krapek, K., King, K., Warren, S. S., George, K. G., Caputo, D. A., Mihelich, K., et al. 2004. Medication adherence and associated hemoglobin A1c in Type 2 diabetes. The Annals of Pharmacotherapy. $38,1357-1362$. 
94. Krishnan, J. A., Riekert, K. A., McCoy, J. V., et al. 2004. Corticosteroid use after hospital discharge among high-risk adults with asthma. Am J Respir Crit Care Med. 170, 1281-1285.

95. Krousel-Wood, M., Joyce, C., Holt, E. W., et al. 2013. Development and evaluation of a self-report tool to predict low pharmacy refill adherence in elderly patients with uncontrolled hypertension. Pharmacotherapy. 33(8), 798-811.

96. Krousel-Wood, M., Muntner, P., Jannu, A., Desalvo, K., Re, R. N. 2005. Reliability of a medication adherence measure in an outpatient setting. The American Journal of the Medical Sciences. 330(3), $128-133$.

97. Krousel-Wood, M., Thomas, S., Muntner, P., Morisky, D. 2004. Medication adherence: A key factor in achieving blood pressure control and good clinical outcomes in hypertensive patients. Current Opinion in Cardiology. 19, 357-362.

98. Lai, C. K. W., De Guia, T. S., Kim, Y. Y., et al. 2003. Asthma control in the Asia-Pacific region: the asthma insights and reality in Asia-Pacific study. Journal of Allergy and Clinical Immunology. 111(2), $263-268$.

99. Lai, C. K., Beasley, R., Crane, J., et al. 2009. Global variation in the prevalence and severity of asthma symptoms: phase three of the International Study of Asthma and Allergies in Childhood (ISAAC). Thorax. 64, 476-483.

100. Lambert, E. V., Steyn, K., Stender, S., Everage, N., Fourie, J. M., Hill, M. 2006. Cross-cultural validation of the hill-bone compliance to high blood pressure therapy scale in a South African, primary healthcare setting. Ethnicity and Disease. 16(1): 286-291.

101. Lavsa, S. M., Holzworth, A, Ansani, N. T. 2011. Selection of a validated scale for measuring medication adherence. Journal of the American Pharmacists Association. 51(1), 90-94.

102. Le, T. T., Bilderback, A., Bender, B., Wamboldt, F. S., Turner, C. F., Rand, C. S., Bartlett, S. J. 2008. Do asthma medication beliefs mediate the relationship between minority status and adherence to therapy? J Asthma. 45(1), 33-37.

103. Legorreta, A. P., Christian-Herman, J., O'Connor, R. D., Hasan, M. M., Evans, R., Leung, K. M. 1998. Compliance with national asthma management guidelines and speciality care: a health maintenance organization experience. Arch Intern Med. 9, 457-464.

104. LeMay, K. S., Armour, C. L, Reddel, H. K. 2014. Performance of a brief asthma control screening tool in community pharmacy: a cross-sectional and prospective longitudinal analysis. Prim Care Respir J. 23(1), 79-84.

105. Leventhal, H., Brisette, I., Leventhal, E. 2003. The Common-Sense Model of Self-regulation of health and illness. In L.D. Cameron\&H. Leventhal (Eds.). The Self-regulation of healthy and illness behavior. New York: Routledge. 42-65.

106. Leventhal, H., Halm, E. A., Horowitz, C. R., Leventhal, E. A., Ozakinci, G. 2004. Living with chronic illness: a contextualized self-regulation approach. In: Sutton, S., Baum, A., Johnston, M., eds. Handbook of Health Psychology. London, England: Sage Publications, 197-240.

107. Leventhal, H., Phillips, L. A., Burns, E. 2016. The Common-Sense Model of Self-Regulation (CSM): a dynamic framework for understanding illness self-management. J Behav Med. 39(6), 935-946.

108. Leynaert, B., Bousquet, J., Neukirch, C., Liard, R., Neukirch, F. 1999. Perennial rhinitis: an independent risk factor for asthma in nonatopic subjects: results from the European Community Respiratory Health Survey. J Allergy Clin Immunol. 104(2 Pt 1), 301-304.

109. Lindberg, M., Ekstrom, T., Moller, M., Ahlner, J. 2001. Asthma care and factors affecting medication compliance: the patient's point of view. International Journal for Quality in Health Care. 13(5), $375-383$.

110. Lozano, R., Naghavi, M., Foreman, K., et al. 2013. Global and regional mortality from 235 causes of death for 20 age groups in 1990 and 2010: a systematic analysis for the Global Burden of Disease Study 2010. Lancet. 380, 2095-2128.

111. Maidment, R., Livingston, G., Katona, C. 2002. Just keep taking the tablets: adherence to antidepressant treatment in older people in primary care. International Journal of Geriatric Psychiatry. $17,752-757$.

112. Mann, D., Ponieman, D., Leventhal, H., Halm, E. A. 2009. Predictors of adherence to diabetes medications: the role of disease and medication beliefs. J Behav Med. 32, 278-284.

113. Marinker, M., Shaw, J. 2003. Not to be taken as directed. BMJ. 326(7385), 348-349.

114. McCoy, K., Shade, D.M., Irvin, C.G., et al. 2006. American Lung Association Asthma Clinical Research Centers. Predicting episodes of poor asthma control in treated patients with asthma. J Allergy Clin Immunol. 118(6), 1226-1233. 
115. McLeish, A. C., Zvolensky, M. J. 2010. Asthma and cigarette smoking: a review of the empirical literature. J Asthma. 47, 345-361.

116. Meltzer, E. O., Busse, W. W., Wenzel, S. E., et al. 2011. Use of the Asthma Control Questionnaire to predict future risk of asthma exacerbation. J Allergy Clin Immunol. 127, 167-172.

117. Menckeberg, T. T., Bouvy, M. L., Bracke, M., et al. 2008. Beliefs about medicines predict refill adherence to inhaled corticosteroids. J Psychosom Res. 64, 47-54.

118. Miedinger, D., Neukomm, E., Chhajed, P. N., et al. 2011. The use of the Asthma Control Test in general practice and its correlation with asthma control according to the GINA guidelines. Current Medical Research and Opinion. 27(12), 2301-2308.

119. Morisky, D. E., Ang, A., Krousel-Wood, M., Ward, H. J. 2008. Predictive validity of a medication adherence measure in an outpatient setting. Journal of Clinical Hypertension. 10(5), 348-354.

120. Morisky, D., Green, L. W., Levine, D. M. 1986. Concurrent and predictive validity of a self-reported measure of medication adherence. Medical Care. 24(1), 67-74.

121. Moss-Morris, R., Weinman, J., Petrie, K. J., Horne, R., Cameron, L. D., Buick, D. 2002. The Revised Illness Perception Questionnaire (IPQ-R). Psychol Health. 17, 1-16.

122. NAEPP (National Asthma Education and Prevention Program). Expert Panel report 3: guidelines for the diagnosis and management 2007. http://www.nhlbi.nih.gov/guidelines/asthma/asthgdln.pdf [viewed 02.10.2017]

123. Nathan, R. A., Sorkness, C. A., Kosinski, M., Schatz, M., Li, J. T., Marcus, P., Murray, J. J., Pendergraft, T. B. 2004. Development of the asthma control test: a survey for assessing asthma control. J Allergy Clin Immunol. 113(1), 59-65.

124. National Asthma Council Australia. 2002. Asthma management handbook. Melbourne: National Asthma Council Australia Ltd.

125. National Asthma Education and Prevention Program. Guidelines for the diagnosis and management of asthma: expert panel report 2. Bethesda: National Institutes of Health, National Heart, Lung and Blood Institute. 1997. Publication No. 97-4051.

126. National Health Service of Latvia. List of specialists allowed to prescribe reimbursed medicines. http://www.vmnvd.gov.lv/lv/503-ligumpartneriem/507-ligumiestazu-saraksts. [viewed 15.03.2018]

127. Neame, R., Hammond, A. 2005. Beliefs about medications: a questionnaire survey of people with rheumatoid arthritis. Rheumatology. 44, 762-767.

128. Neffen, H., Fritscher, C., Schacht, F. C., Levy, G., Chiarella, P., Soriano, J. B., Mechali, D. 2005. AIRLA Survey Group. Asthma control in Latin America: the Asthma Insights and Reality in Latin America (AIRLA) survey. Rev Panam Salud Publica. 17(3), 191-197.

129. Nguyen, T. M., Caze, A. L., Cottrell, N. 2014. What are validated self-report adherence scales really measuring?: a systematic review. British Journal of Clinical Pharmacology. 77(3), 427-445.

130. Nicklas, R. A. 1997. National and international guidelines for the diagnosis and treatment of asthma. Curr Opin Pulm Med. 3, 51-55.

131. O'Brien, M. K., Petrie, K., Raeburn, J. 1992. Adherence to medication regimens: updating a complex medical issue. Med Care Rev. 49, 435-454.

132. O'Byrne, P. M., Reddel, H. K., Eriksson, G., et al. 2010. Measuring asthma control: a comparison of three classification systems. Eur Respir J. 36(2), 269-276.

133. Olszanecka-Glinianowicz, M., Almgren-Rachtan, A. 2014. The adherence and illness perception of patients diagnosed with asthma or chronic obstructive pulmonary disease treated with polytherapy using new generation Cyclohaler. Postepy Dermatol Alergol. 31(4), 235-246.

134. Partridge, M., van der Molen, T., Myrseth, S. E., Busse, W. W. 2006. Attitudes and actions of asthma patients on regular maintenance therapy: the INSPIRE study. BMC Pulmonary Medicine. 6, 13.

135. Pearson, M. G., Bucknall, C. E., eds. 1999. Measuring clinical outcome in asthma: a patient-focused approach. London: Royal College of Physicians.

136. Pedersen, B., Dahl, R., Karlstrom, R., Peterson, C. G., Venge, P. 1996. Eosinophil and neutrophil activity in asthma in a one-year trial with inhaled budesonide. The impact of smoking. Am J Respir Crit Care Med. 153(5), 1519-1529.

137. Peters, S. P., Jones, C. A., Haselkorn, T., Mink, D. R., Valacer, D. J., Weiss, S. T. 2007. Real-world Evaluation of Asthma Control and Treatment (REACT): findings from a national Web-based survey. J Allergy Clin Immunol. 119, 1454-1461.

138. Phatak, H. M., Thomas, J 3rd. 2006. Relationships between beliefs about medications and nonadherence to prescribed chronic medications. Ann Pharmacother. 40(10), 1737-1742. 
139. Pinnock, H., Burton, C., Campbell, S., Gruffydd-Jones, K., Hannon, K., Hoskins, G., Lester, H., Price, D. 2012. Clinical implications of the Royal College of Physicians three questions in routine asthma care: a real-life validation study. Prim Care Respir J. 21(3), 288-294.

140. Ponieman, D., Wisnivesky, J. P., Leventhal, H., Musumeci-Szabó, T. J., Halm, E. A. 2009. Impact of positive and negative beliefs about inhaled corticosteroids on adherence in inner-city asthmatic patients. Annals of Allergy, Asthma and Immunology. 103(1), 38-42.

141. Price, D., Zhang, Q., Kocevar, V. S., Yin, D. D., Thomas, M. 2005. Effect of a concomitant diagnosis of allergic rhinitis on asthma-related health care use by adults. Clin Exp Allergy. 35(3), 282-287.

142. Rabe, K. F., Adachi, M., Lai, C. K., et al. 2004. Worldwide severity and control of asthma in children and adults: the global asthma insights and reality surveys. J Allergy Clin Immunol. 114, 40-47.

143. Rabe, K. F., Vermeire, P. A., Soriano, J. B., et al. 2000. Clinical management of asthma in 1999: the Asthma Insights and Reality in Europe (AIRE) study. Eur Respir J. 16, 802-807.

144. Reddel, H. K., Bateman, E. D., Becker, A., et al. 2015. A summary of the new GINA strategy: a roadmap to asthma control. Eur Respir J. 46(3), 622-639.

145. Reddel, H. K., Taylor, D. R., Bateman, E. D., et al. 2009. American Thoracic Society/European Respiratory Society Task Force on Asthma Control and Exacerbations. An official American Thoracic Society/European Respiratory Society statement: asthma control and exacerbations: standardizing endpoints for clinical asthma trials and clinical practice. Am J Respir Crit Care Med. 180(1), 59-99.

146. Restrepo, R. D., Alvarez, M. T., Wittnebel, L. D., et al. 2009. Medication adherence issues in patients treated for COPD. Int J Chron Obstruct Pulmon Dis. 3, 371-384.

147. Sabate, E. 2003. Adherence to Long-Term Therapies: Evidence for Action. World Health Organization, Geneva, Switzerland.

148. Sastre, J., Olaguibel, J. M., Vega, V., Del Pozo, C., Picado Lopez Via, A. 2010. Cut-off points for defining asthma control in three versions of the asthma control questionnaire. Journal of Asthma.; 47(8), 865-870.

149. Schatz, M., Kosinski, M., Yarlas, A. S., Hanlon, J., Watson, M. E., Jhingran, P. 2009. The minimally important difference of the Asthma Control Test. J Allergy Clin Immunol. 124(4), 719-723.

150. Schatz, M., Mosen, D., Apter, A. J., et al. 2005. Relationships among quality of life, severity, and control measures in asthma: an evaluation using factor analysis. Journal of Allergy and Clinical Immunology. 115(5), 1049-1055.

151. Schatz, M., Sorkness, C. A., Li, J. T., et al. 2006. Asthma Control Test: reliability, validity, and responsiveness in patients not previously followed by asthma specialists. J Allergy Clin Immunol. 117(3), 549-556.

152. Schatz, M., Zeiger, R. S., Yang, S. J., et al. 2012. The relationship of asthma impairment determined by psychometric tools to future asthma exacerbations. Chest. 141(1), 66-72.

153. Solomon, M. D., Majumdar, S. R. 2010. Primary non-adherence of medications: lifting the veil on prescription-filling behaviors. Journal of General Internal Medicine. 25(4), 280-281.

154. Spector, S. 2000. Noncompliance with asthma therapy - are there solutions? J Asthma. 37(5), 381388.

155. Su, N., Lin, J., Chen, P., et al. 2013. Evaluation of asthma control and patient's perception of asthma: findings and analysis of a nationwide questionnaire-based survey in China. Journal of Asthma. 50, 861-870.

156. Suissa, S., Ernst, P., Benayoun, S., Baltzan, M., Cai, B. 2000. Low-dose inhaled corticosteroids and the prevention of death from asthma. $N$ Engl J Med. 343(5), 332-336.

157. Sullivan, S. D., Rasouliyan, L., Russo, P. A., et al. 2007. Extent, patterns, and burden of uncontrolled disease in severe or difficult-to-treat asthma. Allergy. 62(2), 126-133.

158. Sullivan, S. D., Wenzel, S. E., Bresnahan, B. W., et al. 2007. Association of control and risk of severe asthma-related events in severe or difficult-to-treat asthma patients. Allergy. 62(6), 655-660.

159. Sutherland, E. R., Martin, R. J. 2005. Targeting the distal lung in asthma: do inhaled corticosteroids treat all areas of inflammation? Treat Respir Med. 4, 223-229.

160. Svarstad, B. L., Chewning, B. A, Sleath, B. L., Claesson, C. 1999. The brief medication questionnaire: a tool for screening patient adherence and barriers to adherence. Patient Education \& Counseling. $37(2), 113-124$.

161. Tan, X., Patel, I., Chang, J. 2014. Review of the four item Morisky Medication Adherence Scale (MMAS-4) and eight item Morisky Medication Adherence Scale (MMAS-8). Innovations in Pharmacy. 5(3), 165. 
162. Taylor, D. R., Bateman, E. D., Boulet, L. P., et al. 2008. A new perspective on concepts of asthma severity and control. Eur Respir J. 32(3), 545-554.

163. Thomas, M. 2006. Allergic rhinitis: evidence for impact on asthma. BMC Pulm Med. 6(Suppl. 1), S4.

164. Thomas, M., Kay, S., Pike, J., Williams, A., Rosenzweig, J. R., Hillyer, E. V., Price, D. 2009. The Asthma Control Test (ACT) as a predictor of GINA guideline-defined asthma control: analysis of a multinational cross-sectional survey. Prim Care Respir J. 18(1), 41-49.

165. Thomas, M., Kocevar, V. S., Zhang, Q., Yin, D. D., Price, D. 2005. Asthma-related health care resource use among asthmatic children with and without concomitant allergic rhinitis. Pediatrics. $115(1)$

$129-134$.

166. Thompson, K., Kulkarni, J., Sergejew, A. A. 2000. Reliability and validity of a new Medication Adherence Rating Scale (MARS) for the psychoses. Schizophr Res. 42(3), 241-247.

167. Thomson, N. C., Chaudhuri, R. 2009. Asthma in smokers: challenges and opportunities. Curr Opin Pulm Med. 15, 39-45.

168. To, T., Stanojevic, S., Moores, G., et al. 2012. Global asthma prevalence in adults: findings from the cross-sectional world health survey. BMC Public Health. 12, 204.

169. Toll, B. A., McKee, S. A., Martin, D. J., Jatlow, P., O’Malley, S. S. 2007. Factor structure and validity of the Medication Adherence Questionnaire (MAQ) with cigarette smokers trying to quit. Nicotine and Tobacco Research. 9(5), 597-605.

170. Tomlinson, J. E., McMahon, A. D., Chaudhuri, R., Thompson, R. M., Wood, S. F., Thomson, N. C. 2005. Efficacy of low and high dose inhaled corticosteroid in smokers versus non-smokers with mild asthma. Thorax. 60(4), 282-287.

171. Unni, E., Shiyanbola, O. O. 2016. Clustering medication adherence behavior based on beliefs in medicines and illness perceptions in patients taking asthma maintenance medications. Curr Med Res Opin. 32(1), 113-121.

172. Van Steenis, M., Driesenaar, J., Bensing, J., Van Hulten, R., Souverein, P., Van Dijk, L. et al. 2014. Relationship between medication beliefs, self-reported and refill adherence, and symptoms in patients with asthma using inhaled corticosteroids. Patient Prefer. Adherence. 8, 83-91.

173. Verleden, G. M., Dupont, L. J., Verpeut, A. C., Demedts, M. G. 1999. The effect of cigarette smoking on exhaled nitric oxide in mild steroid-naive asthmatics. Chest. 116(1), 59-64.

174. Vermeire, E., Hearnshaw, H., Van Royen, P., Denekens, J. 2001. Patient adherence to treatment: three decades of research. A comprehensive review. Journal of Clinical Pharmacy and Therapeutics. 26(5), 331-342.

175. Vermeire, P. A., Rabe, K. F., Soriano, J. B., Majer, W. C. 2002. Asthma control and differences in management practises across seven European countries. Resp Med. 96, 142-149.

176. Vitolins, M. Z., Rand, C. S., Rapp, S. R., Ribisl, P. M., Sevick, M. A. 2000. Measuring adherence to behavioral and medical interventions. Controlled Clinical Trials. 21(5), 188S-194S.

177. Vollmer, W. M., Markson, L. E., O'Connor, E., et al. 1999. Association of asthma control with health care utilization and quality of life. American Journal of Respiratory and Critical Care Medicine. 160(5), 1647-1652.

178. Vollmer, W. M., Markson, L. E., O'Connor, E., et al. 2002. Association of asthma control with health care utilization: a prospective evaluation. American Journal of Respiratory and Critical Care Medicine. 165(2), 195-199.

179. Vos, T., Flaxman, A. D., Naghavi, M., et al. 2012. Years lived with disability (YLDs) for 1160 sequelae of 289 diseases andinjuries 1990-2010: a systematic analysis for the Global Burden of Disease Study 2010. Lancet. 380, 2163-2196.

180. Vrijens, B, de Geest, S., Hughes, D. A., et al. 2012. A new taxonomy for describing and defining adherence to medications. British Journal of Clinical Pharmacology. 73(5), 691-705.

181. Vrijens, B., Dima, A. L., Van Ganse, E., et al. 2016. What We Mean When We Talk About Adherence in Respiratory. J Allergy Clin Immunol Pract. 4(5), 802-812.

182. Weinman, J., Petrie, K. J., Moss-Morris, R., Horne, R. 1996. The Illness Perception Questionnaire: a new method for assessing the cognitive representation of illness. Psychol Health. 11, 431-445.

183. Weiss, K., Buxton, M., Andersson, F. L., et al. 2006. Cost-effectiveness of early intervention with once-daily budesonide in children with mild persistent asthma: results from the START study. Pediatric Allergy and Immunology. 17(17), 21-27. 
184. Weldam, S. W., Lammers, J. W., Heijmans, M. J., Schuurmans, M. J. 2014. Perceived quality of life in chronic obstructive pulmonary disease patients: a cross-sectional study in primary care on the role of illness perceptions. BMC Fam Pract. 15, 140.

185. Wells, K., Pladevall, M., Peterson, E. L., Campbell, J., Wang, M., Lanfear, D. E., Williams, L. K. 2008. Race-ethnic differences in factors associated with inhaled steroid adherence among adults with asthma. Am J Respir Crit Care Med. 178(12), 1194-1201.

186. Westerik, J. A., Carter, V., Chrystyn, H., Burden, A., Thompson, S. L., Ryan, D. 2016. Characteristics of patients making serious inhaler errors with a dry powder inhaler and association with asthma-related events in a primary care setting. J Asthma. 53, 231-239.

187. Williams, L. K., Pladevall, M., Xi H., et al. 2004. Relationship between adherence to inhaled corticosteroids and poor outcomes among adults with asthma. The Journal of Allergy and Clinical Immunology. 114(6), 1288-1293.

188. Wilson, S. R., Strub, P., Buist, A. S., et al. 2010. Shared treatment decision making improves adherence and outcomes in poorly controlled asthma. American Journal of Respiratory and Critical Care Medicine. 181(6), 566-577.

189. Wright, M. T. 2000. The old problem of adherence: research on treatment adherence and its relevance for HIV/AIDS. AIDS Care. 12, 703-710.

190. Wroe, A. L. 2002. Intentional and unintentional nonadherence: a study of decision making. J Behav Med. 25, 355-372.

191. Yildiz, F. 2013. ASIT Study Group. Factors influencing asthma control: results of a real-life prospective observational asthma inhaler treatment (ASIT) study. Journal of Asthma and Allergy. 6, 93-101.

192. Yin Lam, W., Fresco, P. 2015. Medication Adherence Measures: An Overview. Biomed Res Int. 217047. 


\section{Individual publications}

1. Šmits, D. Bronhiālās astmas slimnieku uzskati par ārstēšanu un to saistība ar viṇu slimības kontroles pakāpi. 2016. gada Zinātniskās konferences tēzes (RSU. Rīga, 2016.g. 17.-18.martā). Rīgas Stradiña universitāte. 79. 1pp.

2. Šmits, D. Bronhiālās astmas zāḷu lietošanas līdzestība Latvijas pacientiem. 2013. gada Zinātniskās konferences tēzes (Rīga, 2013.g. 21.-22. martā). Rīgas Stradiña universitāte. 74. lpp.

3. Šmits, D. Factors related to good asthma control in Latvian asthma patients in 2015. $6^{\text {th }}$ International Interdisciplinary Scientific Conference "Society. Health. Welfare: Living in the World of Diversity: Social Transformations. Innovations. Solutions" (RSU. Riga, Nov. 23-25, 2016): Abs.

4. Smits, D. Factors related to good treatment adherence in asthma patients in Latvia in 2015. $9^{\text {th }}$ European Public Health Conference 2016, Vienna, Austria. Abs. ref.: S201600013.

5. Smits, D., Brigis, G., Pavare, J, Maurina, B., Barengo, N. C. 2017. Factors related to poor asthma control in Latvian asthma patients between 2013 and 2015. Scand J Prim Health Care. 35(2), 186-191. doi: 10.1080/02813432.2017.1333302. Epub 2017 Jun 6.

6. Smits, D., Brigis, G., Pavare, J., Maurina, B., Barengo, N. C. 2017. Factors related to good asthma control using different medical adherence scales in Latvian asthma patients: an observational study. NPJ Prim Care Respir Med. 27(1), 39. doi: 10.1038/s41533-017-0042-x. 


\section{ATTACHMENTS}

(Latvian language questionnaires used in the research) 


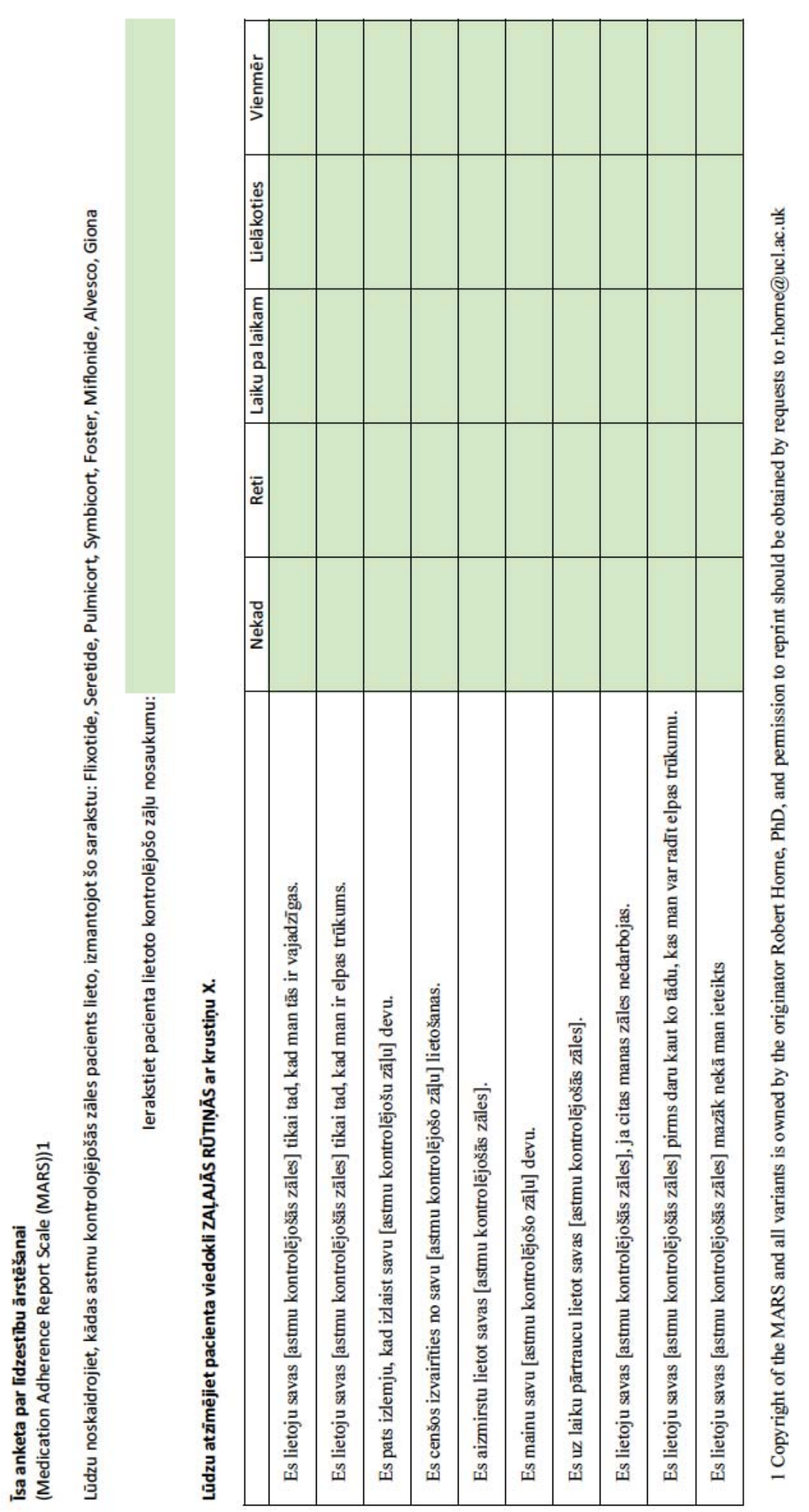




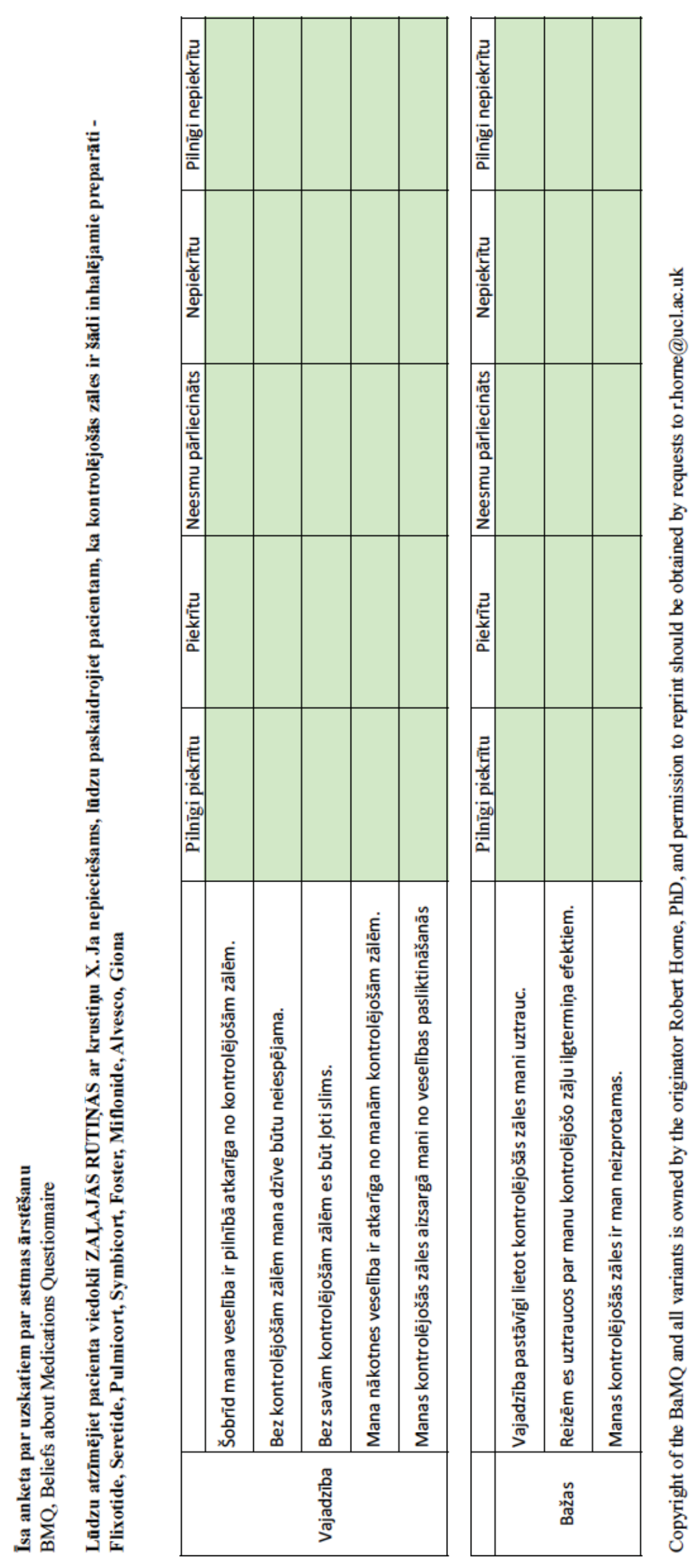


Viedoklis par astmu kā slimību

Lūdzu ar krustiṇu $X$ atzīmējiet pacienta izvēlēto atbildi ZAḶAJĀS RŪTIṆĀS

\begin{tabular}{|l|l|l|}
\hline \multicolumn{2}{|c|}{ Kā jūs domtitāte } \\
$\qquad$\begin{tabular}{|l|l|}
\hline visuat, vai astma ir kaut kas, kas jums ir ... & \\
\hline lielāko laika dal̦u? & \\
\hline dažreiz? & \\
\hline tikai, kad jūtu simptomus? & \\
\hline
\end{tabular}
\end{tabular}

\begin{tabular}{|l|l|l|}
\hline Laiks Vai jūs domājat, ka jums vienmēr būs astma? \\
$\qquad$\begin{tabular}{|l|l|}
\hline Pilnīgi noteikti & \\
\hline Tas ir ticams & \\
\hline Iespējams & \\
\hline Nē & \\
\hline
\end{tabular}
\end{tabular}

\begin{tabular}{|l|l|l|}
\hline Kontrole Vai jūs sagaidāt, ka ārsts pilnībā izārstēs jūsu astmu? \\
$\qquad$\begin{tabular}{|l|l|}
\hline Noteikti & \\
\hline Tas ir ticams & \\
\hline Iespējams & \\
\hline Nē & \\
\hline
\end{tabular}
\end{tabular}




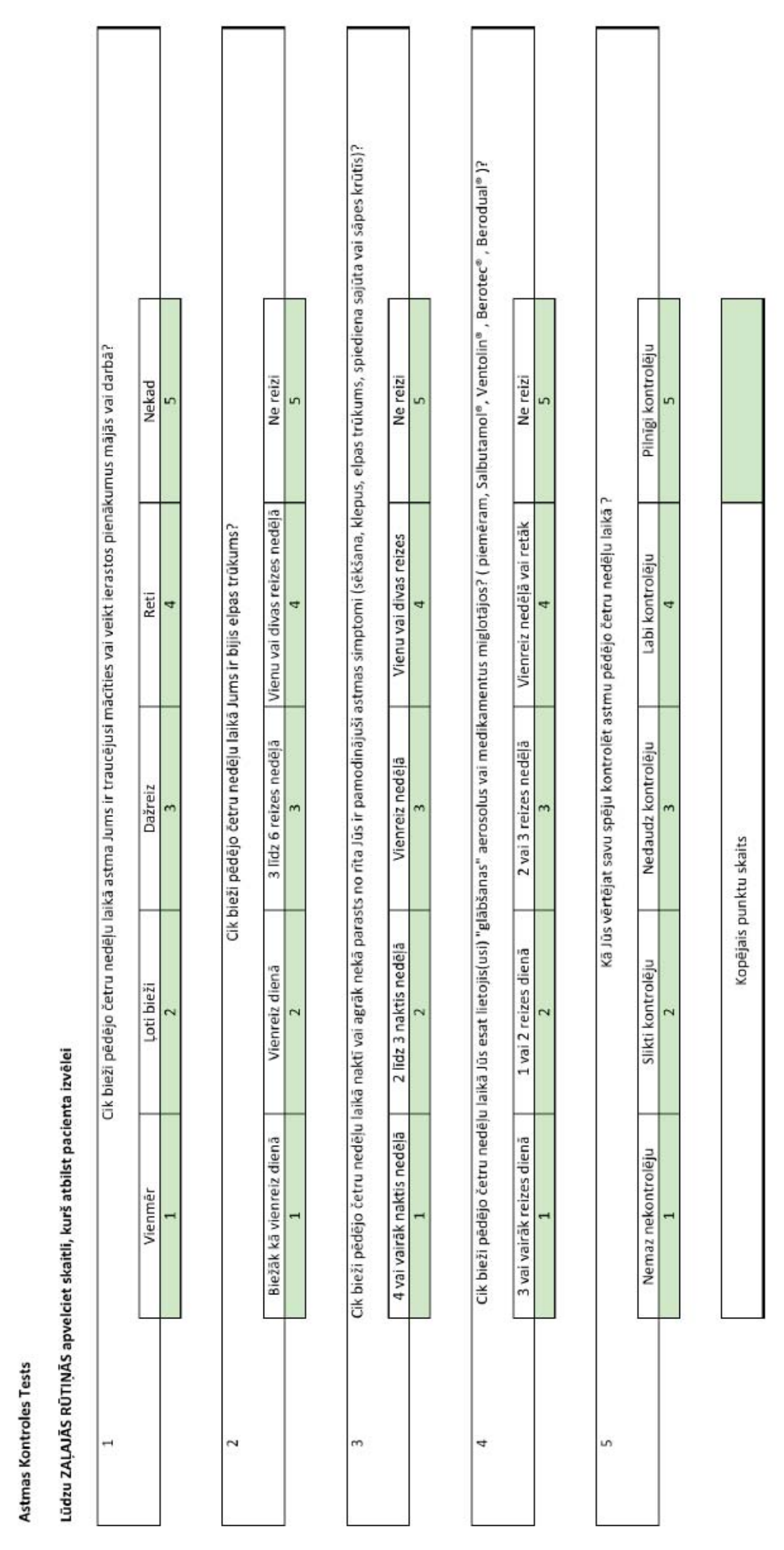




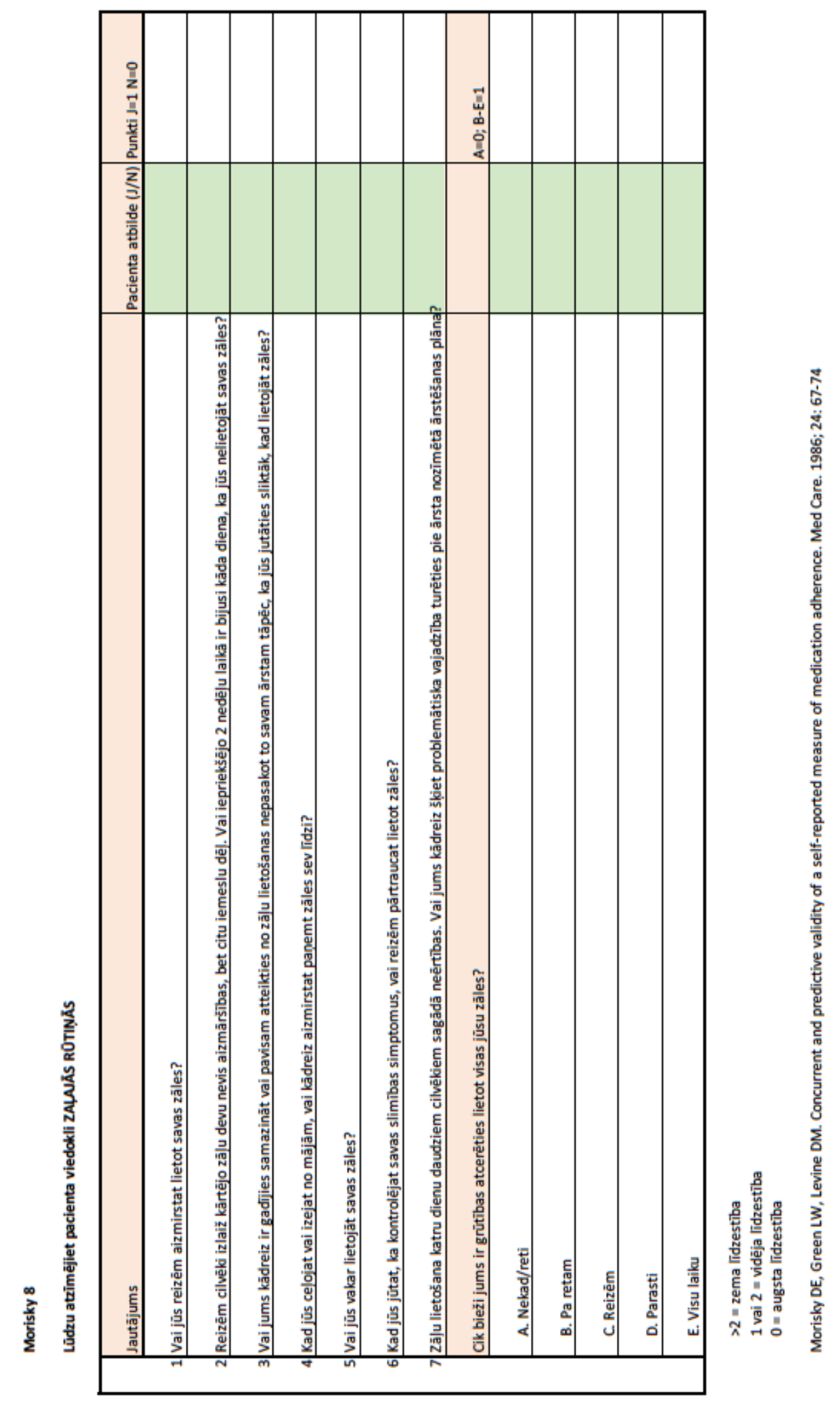


İsā uzskatu par slimību anketa $\quad$ B-IPQ

(The Brief Illness Perception Questionnaire

Lũdzu anketā atzīmējiet ar krustịnu $X$ pacienta vērtējumu katrā no jautājumiem

Cik daudz jūsu slimība ietekmē jūsu dz̄̄ị?

\begin{tabular}{|c|c|c|c|c|c|c|c|c|c|c|}
\hline 0 & 1 & 2 & 3 & 4 & 5 & 6 & 7 & 8 & 9 & 10 \\
\hline Nemaz neietekmẽ
\end{tabular}

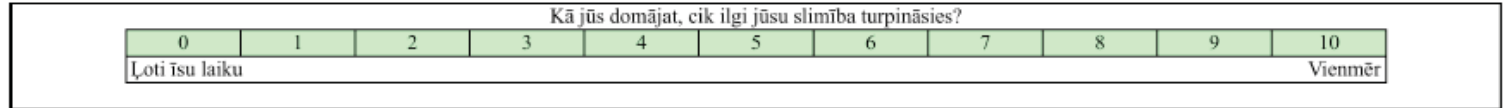

\begin{tabular}{|c|c|c|c|c|c|c|c|c|c|c|}
\hline \multicolumn{11}{|c|}{ Kā jūs jūtat, cik liela ir jūsu kontrole pār jūsu slimību? } \\
\hline 0 & 1 & 2 & 3 & 4 & 5 & 6 & 7 & 8 & 9 & 10 \\
\hline \multicolumn{9}{|c|}{ Nekādas kontroles } & \multicolumn{2}{|c|}{ Pilnīga kontrole } \\
\hline
\end{tabular}

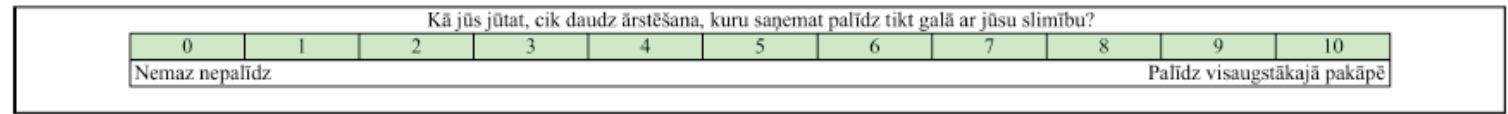

\begin{tabular}{|c|c|c|c|c|c|c|c|c|c|c|}
\hline \multicolumn{11}{|c|}{ Cik daudz jūs piedzīvojat savas slimības pazīmes/simptomus? } \\
\hline 0 & 1 & 2 & 3 & 4 & 5 & 6 & 7 & 8 & 9 & 10 \\
\hline \multicolumn{8}{|c|}{ Nekādu pazīmju/simptomu nav } & \multicolumn{3}{|c|}{ Daudz un izteiktas pazimes/simptomus } \\
\hline
\end{tabular}

\begin{tabular}{|c|c|c|c|c|c|c|c|c|c|c|}
\hline \multicolumn{11}{|c|}{ Cik loti jūs uztraucaties par savu slimību? } \\
\hline 0 & 1 & 2 & 3 & 4 & 5 & 6 & 7 & 8 & 9 & 10 \\
\hline \multicolumn{11}{|c|}{\begin{tabular}{|l|} 
Nemaz neuztraucos \\
\end{tabular}} \\
\hline
\end{tabular}

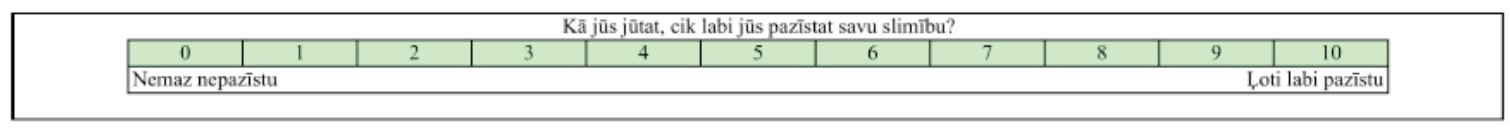

\begin{tabular}{|c|c|c|c|c|c|c|c|c|c|c|}
\hline \multicolumn{11}{|c|}{ Cik lielā mêrā jūsu slimība jūs ietekmē emocionāli? (piem., vai tā jūs sadusmo, biedê, uztrauc vai rada depresiju?) } \\
\hline 0 & 1 & 2 & 3 & 4 & 5 & 6 & 7 & 8 & 9 & 10 \\
\hline \multicolumn{10}{|c|}{ Nemaz neietekmē } & Loti ietekmē \\
\hline
\end{tabular}

Lūdzu sarindojiet svarīguma secībā trīs faktorus, kuri jūsuprāt izraisīja jūsu slimību.

Trīs svarīgākās lietas, kuras izraisīja manu slimību ir: 
Demogrāfiskie parametri

\begin{tabular}{|c|c|}
\hline & $\mathrm{V}$ \\
\hline Dzimums & $\mathrm{S}$ \\
\hline
\end{tabular}

Vecums, pilni gadi

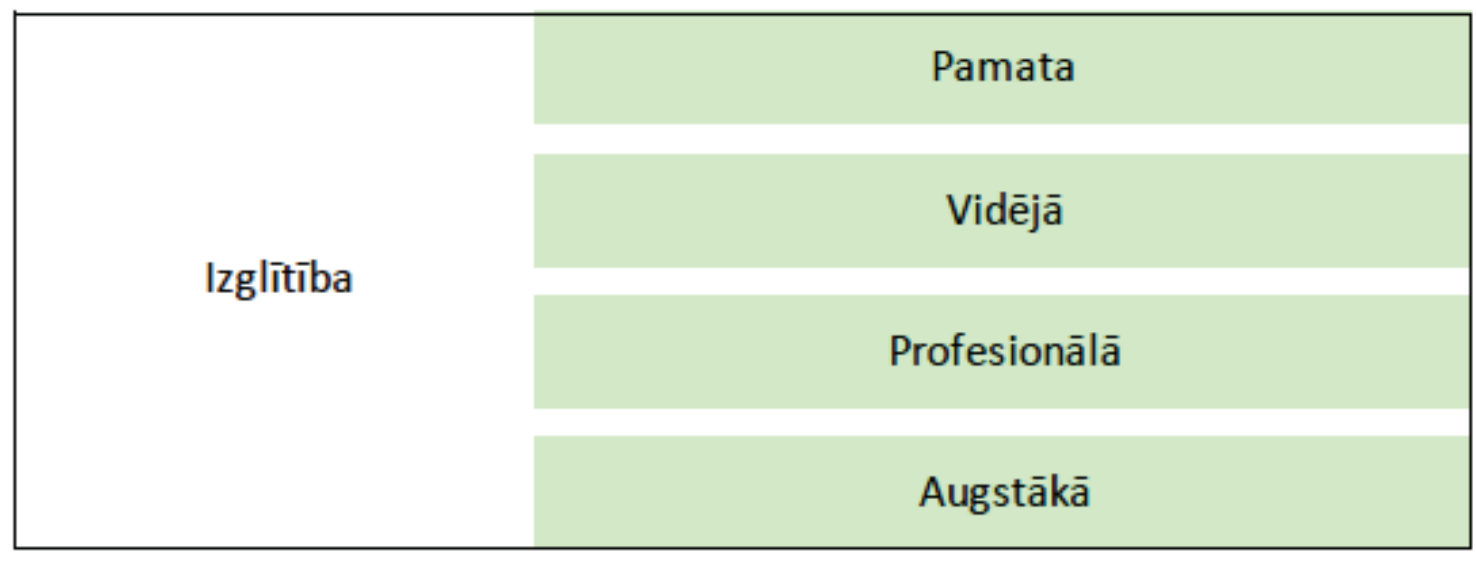

\begin{tabular}{|c|c|}
\hline & mazāk nekā 300 \\
\hline $\begin{array}{c}\text { lenākumi, EUR mēnesī } \\
\text { bruto }\end{array}$ & $300-550$ \\
& $550-750$ \\
\hline Dzìvo & vairāk nekā 750 \\
\hline
\end{tabular}




\section{Ethics Committee approval}

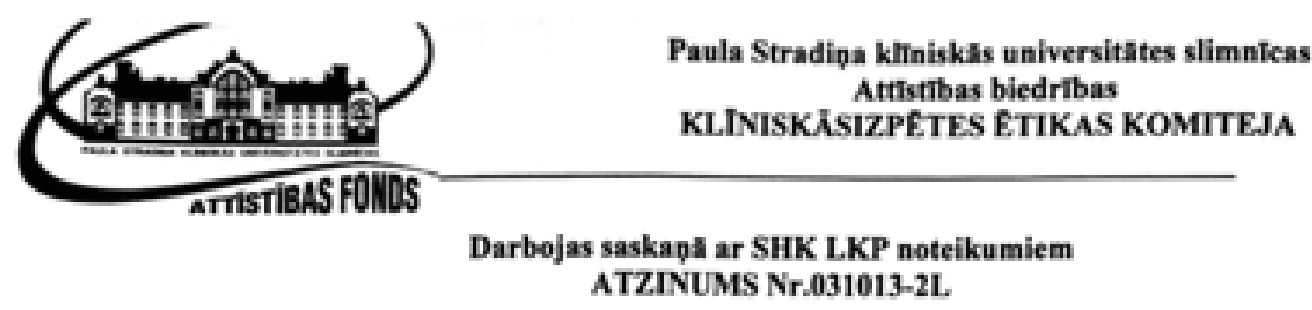

1. Peđjuma nosaukums: Bronhiālăs pacientu lidzestiba årstę̧anai Latvijă un to ietekmějosie faktori.

2. Protokola Nrat nav

3. Pêtnieka vârds, uxvârds:

Rigas Stradipa universitătes doktorants Dins Ŝmits darba vaditajs prof. Girts Brigis

4. Irskatitie un apstiprinatie dokumenti:

4.1. pieteikums at|aujas sapemSanai ar pitojuma aprakstu.

4.2. pacienta informëtlis piekribanas forma

4.3. petijuma ietvaros aizpildimo anketu paraugi

5. Etikas komitejas atraums - pozitivs

6. Etikas komitejas locek|i, kuri piedalijls balsołana:
Pêteris Stradips - kardiokinurgs Irina Vinnika - biologs
Ilze Aizsilniece - gimenes ârsts Santa Purvipa - farmakologs
Biruta Kupca - psihiatrs Petteris Ersts - jurist:
Dainis Krievips - asinsvadu kirurgs Inga Vigante - filologs
Valdis Prilgs - endokrinologs

7. Etikas komitejas sễes datums: 2013.gada 3.oktobrt.

Etikas komitejas priek̋skdztajs:

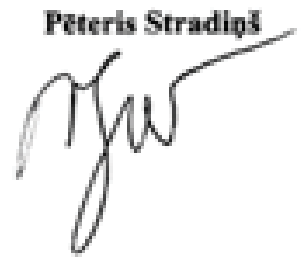

Paula Stradiega kliniskass universitstes slimnicas Atristibas biedriba

Pilsopu 13, Riga, LV- 1002, Tel. +371 26390055 fakss + 371 67069946; E - pasts: etikas-komiteja@stradini.lv 